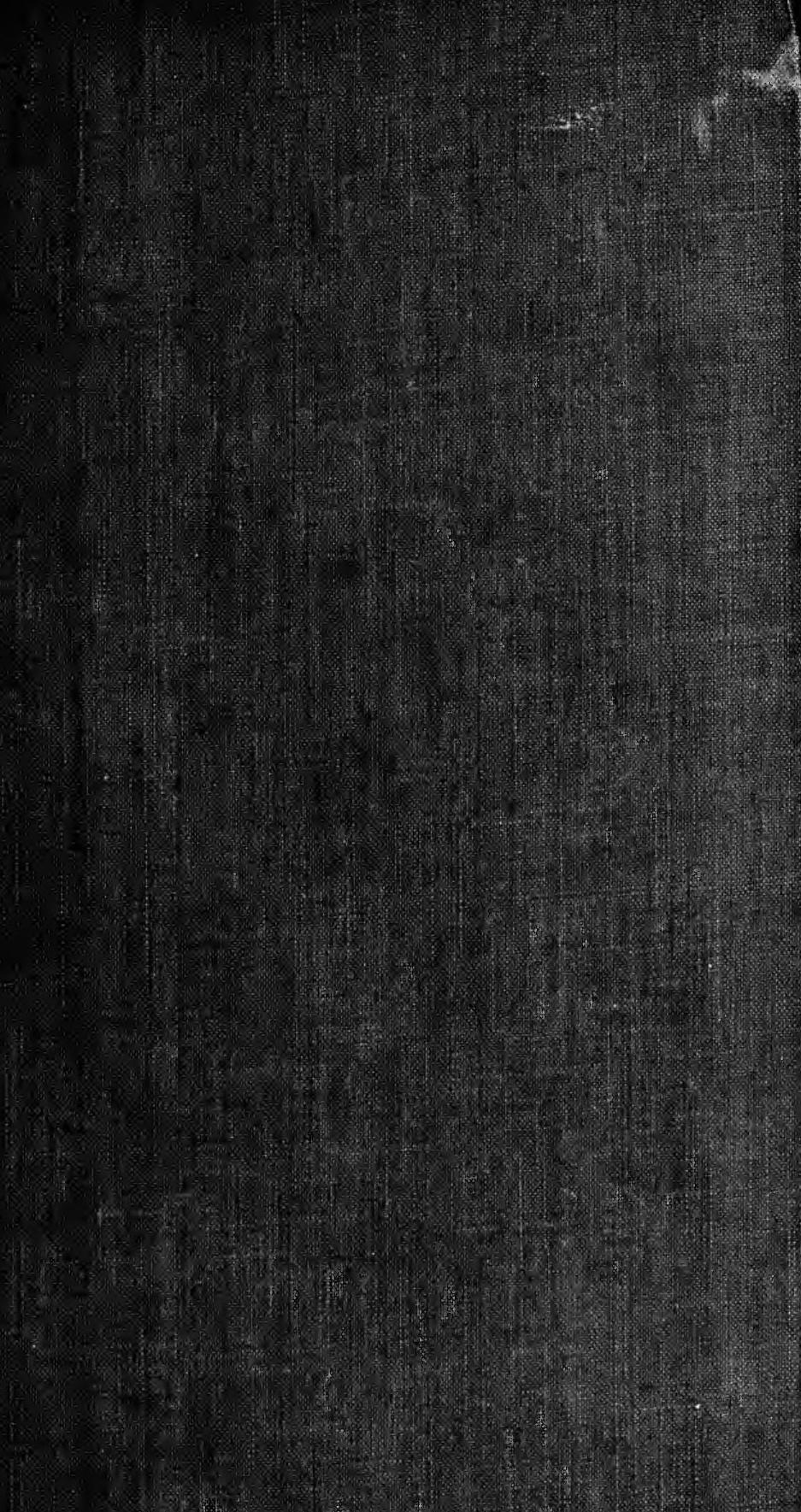





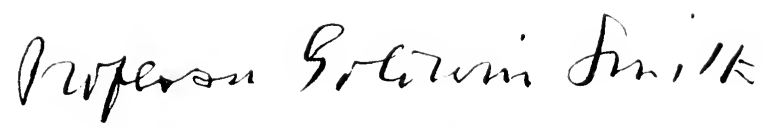
wit ilu kagus? Gruman flaw.reph 



\section{THE LAW AND POLICY OF ANNEXATION}





\title{
THE LAW AND POLICY
}

\section{OF ANNEXATION}

WITH SPECIAL REFERENCE TO

THE PHILIPPINES

TOGETHER WITH

OBSERVATIONS ON THE STATUS OF CUBA

\author{
BY
}

\section{CARMAN F. RANDOLPH}

OF THE NEW YORK BAR

AUTHOR OF "THE LAW OF EMINENT DOMAIN"

LONGMANS, GREEN, AND CO.

91 AND 93 FIFTH AVENUE, NEW YORK LONDON AND BOMBAY

1901 
Copyright, I901, by

CaRMAN F. RANDOLPH

The de Vinne Press. 
To My Mother 
Digitized by the Internet Archive in 2007 with funding from Microsoft Corporation 


\section{PREFACE}

The annexation of the Philippines is the immediate reason for this book, which, in dealing with the event itself, advocates withdrawal of our sovereignty from the islands, and suggests a method for its accomplishment. In the larger and permanent purpose of the book the event is but the text for a general discussion of annexation, with regard to the policies proper for the guidance of the United States in the matter of enlarging their territory, and to the obligations that go with their sovereignty.

These obligations are partly of a moral nature, and partly are determined by the Constitution. Some of the questions of constitutional law involving the taxation of commerce have been argued before the Supreme Court in causes now under advisement, and may be adjudicated before this book is published: Yet I have written positively on the whole question of constitutional obligation because I believe that in theory of law the Constitution is supreme throughout the jurisdiction of Congress, and because its supremacy is a principle generally held by our people, 
commonly respected by our Government, and recognized by our courts.

The true policies of the republic discourage any assumption of sovereignty over land and people that tends to weaken our institutions, or lower the quality of our civic body, or dull our sense of justice.

Morristown, New Jersey, January, $\mathbf{1} 9 \circ \mathrm{I}$.

NOTE.-I have incorporated in this book parts of two pamphlets: "Constitutional Aspects of Annexation," December, 1898, Harvard Law Review, January, 1899; reprinted in the Congressional Record, January II, I899; and "Notes on the Law of Territorial Expansion," March, 1900, reprinted in the Record, March 3I, Igoo. 


\title{
CONTENTS
}

\author{
CHAPTER I
}

THE ANNEXATION OF THE PHILIPPINES

THE SPANISH TITLE............ . I

ACQUISITION BY THE UNITED STATES. . . . 4

The Right and the Method........... . 4

The Purpose of Acquisition. . . . . . . . . . 8

Our Title under the Treaty of Paris . . . . . Io

THE EFFECT OF ACQUISITION ....... 12

\section{CHAPTER II}

\section{THE CONSTITUTION AND THE PHILIPPINES}

ARGUMENTS AGAINST THE RULE OF THE CONSTITUTION EXAMINED......... . 29

That the Constitution is not Self-extending . . 29

That the Constitution is not Effective beyond the

North American Continent . . . . . . . 34

That the Constitution was Ordained for the States

AlONE . . . . . . . . . . . 35

That the Power of the United States over ANnexed Territory is the Same as that Possessed by Other Nations . . . . . . . . . . . . 43 


\section{CHAPTER III}

THE APPLICATION OF THE CONSTITUTION IN THE PHILIPPINES

STATUS OF PERSONS. . . . . . . . . $5^{2}$

Natural-Born Citizens . . . . . . . . . $5^{2}$

Indians AND Foreigners . . . . . . . . . 57

The Privilege of Election - The Plebiscite. . . . 59

Change of Nationality . . . . . . . . . . 6I

Naturalized Citizens . . . . . . . . . . . $66_{3}$

Slavery . . . . . . . . . . . . . . 65

RIGHTS OF PERSONS ........... . . 70

Political Franchises . . . . . . . . . . . 70

Civil Rights . . . . . . . . . . . . . . 7 I

TAXATION_COMMERCE . . . . . . . . . . 76

Foreign Commerce . . . . . . . . . . . . 76

Donestic Commerce . . . . . . . . . . . . 78

The Porto Rico Act . . . . . . . . . . . . . 82

The Commercial Unity of the United States . . 9

VALUE OF THE CONSTITUTION IN NEW TER-

RITORY . . . . . . . . . . . . . . . . . 98

CONCLUSIONS IN REGARD TO THE CONSTITU-

TION . . . . . . . . . . IO2

\section{CHAPTER IV}

THE GOVERNING OF THE PHILIPPINES

THE POWERS OF THE PRESIDENT . . . . . I06

Executive Powers . . . . . . . . . . . 106

Usurpation of Legislative Power . . . . . . . 109 THE POWERS OF CONGRESS . . . . . . . $12 \mathrm{I}$

Source and Extent of Congressional Powers. . . I 22

The Exercise of Congressjonal Powers . . . . I 125 
OUR RELATION TO THE OLD ORDER . . . I 30 THE Old laws ............ . . . I30 Language . . . . . . . . . . . . 138 Religious Institutions . . . . . . . . . . . I40

\section{CHAPTER V}

\section{THE ALIENATION OF THE PHILIPPINES}

THE RIGHT OF ALIENATION . . . . . . 146 THE TERMS OF ALIENATION - THE PROTEC-

TORATE .............. 148 THE EXPEDIENCY OF ALIENATION . . . . ${ }_{15} 8$

Commercial Considerations. . . . . . . . . 158

Moral and Political Considerations . . . . . i i6I

OBSERVATIONS ON THE STATUS OF CUBA . . I73

\section{APPENDIX OF DOCUMENTS}

Joint Resolution in Regard to Cuba . . . . . 193 DECLARATION OF WAR . . . . . . . . . . I94 PROTOCOL OF AUGUST 12, 1898 . . . . . . . . . 194 Proclamation of the Protocol . . . . . . . 196 TREATY OF PARIS . . . . . . . . . . . . . . . . . 197 ACT OF MARCH 21, 1899.......... . 204

Lease of Kiao-chau . . . . . . . . . . . 205 Charter German Colonization Society . . . . 208 French Protectorate over Madagascar. . . . . 209 Transfer of Mysore to a Native Ruler . . . . 2 i 2 Lagos Protectorate Order in Council . . . . 217

INDEX OF CASES ........... $22 \mathrm{I}$

GENERAL INDEX .......... 223 



\section{CHAPTER I}

\section{THE ANNEXATION OF THE PHILIPPINES}

\section{THE SPANISH TITLE}

T ONG ago, Spain became entitled to the Philippine L Islands in accordance with the public law of the period respecting the discovery and occupation of land. The application of this law in America has been described by Chief Justice Marshall in terms pertinent in regard to the Indies: "On the dis"covery of this immense continent, the great nations "of Europe were eager to appropriate to themselves "so much of it as they could respectively acquire. "Its vast extent offered an ample field to the ambi"tion and enterprise of all; and the character and "religion of its inhabitants afforded an apology for "considering them as a people over whom the superior "genius of Europe might claim an ascendancy. The "potentates of the old world found no difficulty in "convincing themselves that they made ample com"pensation to the inhabitants of the new by be"stowing on them civilization and Christianity in " exchange for unlimited independence. But, as they "were all in pursuit of nearly the same object, it was " necessary, in order to avoid conflicting settlements "and consequent war with each other, to establish a "principle which all should acknowledge as the law "by which the right of acquisition, which they all 



\section{CHAPTER I}

\section{THE ANNEXATION OF THE PHILIPPINES}

\section{THE SPANISH TITLE}

ONG ago, Spain became entitled to the Philippine L Islands in accordance with the public law of the period respecting the discovery and occupation of land. The application of this law in America has been described by Chief Justice Marshall in terms pertinent in regard to the Indies: "On the dis" covery of this immense continent, the great nations "of Europe were eager to appropriate to themselves "so much of it as they could respectively acquire. "Its vast extent offered an ample field to the ambi"tion and enterprise of all; and the character and "religion of its inhabitants afforded an apology for " considering them as a people over whom the superior "genius of Europe might claim an ascendancy. The "potentates of the old world found no difficulty in "convincing themselves that they made ample com"pensation to the inhabitants of the new by be"stowing on them civilization and Christianity in " exchange for unlimited independence. But, as they "were all in pursuit of nearly the same object, it was "necessary, in order to avoid conflicting settlements " and consequent war with each other, to establish a "principle which all should acknowledge as the law "by which the right of acquisition, which they all 
" asserted, should be regulated as between them"selves. This principle was that discovery gave " title to the government by whose subjects, or by "whose authority, it was made, against all other "European governments, which title might be "consummated by possession.

"The exclusion of all other Europeans necessarily "gave to the nation making the discovery the sole "right of acquiring the soil from the natives and " establishing settlements upon it. It was a right "with which no Europeans could interfere. It was " a right which all asserted for themselves, and to the "assertion of which, by others, all assented." 1

The circumstances of Spain's tenure of the Philippines are of historical rather than legal interest, for the law in respect of national title to land takes no account of its origin, nor of any subsequent transfers which in private transactions would form what is called a chain of title. The state having possession under claim of title is regarded as the sovereign proprietor without reference to the manner of acquiring it. Often this rule secures the fruits of oppression and fraud, yet none other is practicable. As the alternative of disorder, the status quo demands respect from the generality of states until, through some convulsion of war, or some compact a new order comes into being, thenceforth legitimated until it in turn shall be changed. And through just war or compact lands held wrongfully are sometimes regained by their proper sovereigns.

According to these principles Spain, at the out-

${ }^{1}$ Johnson $v$. McIntosh, 8 Wheaton 543, 572. 
break of the war, possessed the Philippines in exclusive sovereignty. That she had not reclaimed all parts of the Archipelago, nor bent all its savage tribes to her will no more affected her possession than did like shortcomings affect our possession of the western wilderness in earlier days.

But some contend that the title enjoyed by Spain at the beginning of the war was, at the making of the Treaty of Paris, so shattered by insurgent Filipinos that Spain had really nothing to convey to the United States. This declaration is based on a questionable fact and a serious misapprehension of law. From the battle of Manila Bay to the capture of Manila the insurrection is not separable from our campaign. Our hostile preparations revived it; our ships brought back its leader; our aid made it so formidable that when Manila fell Spain was mistress only of the few towns in which her troops were huddled. During this period the insurgents were, practically, our allies, and it is contemptible to belittle, now, their service in arraying the native population against Spain. Yet the relation was not that equal alliance between states which creates reciprocal obligations under international law, ${ }^{1}$ but rather an unequal alliance between a state and a rebellious people who make common cause against the latter's sovereign.

Even if a just estimation of the facts had approved the claim of the insurgents to an independent conquest of the greater part of the islands, they would not have made good a legal title to the land against Spain: For a state does not lose title through insurrection unless an insurgent government holds

1 See The Resolution, 2 Dallas I. 
territory beyond the likelihood of reconquest; and recognition of this government by neutral states is, generally, the sign of a new order.

The United States have respected this rule abroad, notably in insurrections of Spanish-American colonies. They succeeded in securing its benefit for themselves in the Civil War, when, during four years, an insurgent government governed a large territory from a fixed capital, and kept great armies in the field: And, though the proper application of the rule is always a matter of delicacy, technically, the United States have acted within their rights in accepting it in the case of the Philippines.

Finally, the United States have put all question of Spain's title beyond discussion. By accepting the islands from her hands, they have determined its sufficiency for themselves, and no other nation is concerned to question it.

Being entitled to the Philippines, Spain had the legal right to cede them, as well by the particular law of her Constitution as by the principles of public law.

ACQUISITION BY THE UNITED STATES

\section{The Right and the Method}

The United States have the right to enlarge their territory, and the field of its exercise is not restricted by any legal limitation. "The Constitution confers "absolutely on the government of the Union the 
" powers of making war and of making treaties ;" says Chief Justice Marshall, "consequently that govern"ment possesses the power of acquiring territory "either by conquest or by treaty."

While the moral purpose of the war power is figured in Taney's declaration: "The genius and "character of our institutions are peaceful, and the " power to declare war was not conferred upon Con"gress for the purpose of aggression or aggrandize"ment, but to enable the general government to vindi"cate by arms, if it should become necessary, its own "rights and the rights of its citizens "; ${ }^{2}$ yet, if aggrandizement shall follow a war declared for whatever reason, we must hold with Marshall, that "conquest "gives a title which the courts of the conqueror can" not deny, whatever the private and speculative "opinions of individuals may be respecting the ori"ginal justice of the claim which has been successfully "asserted." ${ }^{3}$

A state may also add to its domain by discovery and settlement, and the Supreme Court has recognized this method of acquisition as being approved by the law of nations; ${ }^{4}$ though it may be approved more satisfactorily as being inferred from the more apposite constitutional powers of contract and conquest: If a nation can buy or seize land, surely it can find and keep land.

Reliance upon national, rather than international

1 American Ins. Co. $v$. Canter, I Peters 5 Ir, 54 r.

${ }^{2}$ Fleming $v$. Page, 9 Howard 603, 6r4.

${ }^{3}$ Johnson $v$. McIntosh, 8 Wheaton $543,588$.

${ }^{4}$ Johnson $v$. McIntosh, 8 Wheaton 543 ; Jones $v$. U.S., 137 U.S. 202, 2 I 2 ; Shively $v$. Bowlby, I 52 U. S. $1,50$. 
law as the basis of our national powers is usually enjoined by the superior value of the domestic law in this relation. When Lord Mansfield said that an act of Parliament "did not intend to alter, nor can " alter, the law of nations," ${ }^{1}$ he stated merely the selfevident fact that the legislature of a single country cannot change a body of principles which derives its repute from the assent of all countries. He did not mean that a legislature is dominated by the law of nations. ${ }^{2}$ This law ought to be respected wherever it is clearly ascertained, even at great cost to national pride, if for no higher reason than this, that deference accorded to-day strengthens a demand for deference to-morrow. Our Constitution enjoys the unique distinction, I believe, of commending this law to its courts, and American jurists have done much to broaden and strengthen its influence. But in all matters of domestic interest the United States should find their sufficient powers in the domestic law which they ordain and control. This caution is timely, because there is a perverse disposition to determine our relations with Porto Rico and the Philippines by international law, in contempt of the truth that by assuming complete sovereignty over these islands we have eliminated this law from our reckoning.

Texas and Hawaii were annexed by joint resolution of the Senate and House, ${ }^{3}$ because treaties of cession could not command the necessary two-thirds

${ }^{1}$ Heathfield $v$. Chilton, 4 Burr. 2016.

${ }^{2}$ See also Savigny, Conflict of Laws, Guthrie's translation, $2 \mathrm{~d}$ ed., p. 75 , note.

${ }^{3}$ U. S. Statutes at Large, ix, ro8; $\mathrm{xxx}, 75^{\circ}$. 
vote in the Senate. This method is as effective as a treaty, though the reasons for its actual employment have subjected it to political criticism. Indeed, the case is conceivable where a resolution or act of Congress may be the only formal method of annexation; if, for example, we should now annex Cuba, in despite of our promise; an act or resolution would be the most orderly means to the end, because there is no state in $\mathrm{Cuba}$, at present, with whom we can make a treaty.

Annexation should be accomplished through formal procedure, yet, after all, it is so far a matter of fact that a case may arise where it would be inferred from an actual subjection of territory to our legislative and executive jurisdiction, without preliminary formalities.

Whenever the President and Congress join in extending the sovereignty of the United States over a particular territory their action must be respected by the courts, without regard to its location. "Who "is the sovereign de jure and de facto of a territory," says the Supreme Court, "is not a judicial but a "political question, the determination of which, by "the legislative and executive departments of any "government conclusively binds the judges, as well "as all other officers, citizens, and subjects of that "government. This principle has always been up"held by this court, and has been affirmed under a " great variety of circumstances." 1

${ }^{1}$ Jones v. U. S., 137 U. S. 202, 212 ; citing among American cases Gelston $v$. Hoyt, 3 Wheaton 296, 324; Foster $v$. Neilson, 2 Peters 253, 307, 309; and, among English cases, Emperor of Austria $v$. Day, 3 De G. F. \& J. 217, 221, 233. 


\section{The Purpose of Acquisition}

Is the power to annex conditioned upon the formation of States out of the new territory? This question is not suggested by the acquisition of small tracts for specific governmental uses, such as coalingstations, or of vacant guano islands under the Act of $185^{6 .}$ Nor can it be urged as a legal objection to an annexation that the country has not been annexed as a State, or in express contemplation of future statehood, for the admission of a State is, like the selection of territory, a political matter beyond the competency of the courts. But, according to the spirit of the Constitution, the subjection of annexed territory to exclusive federal control is, generally, an abnormal and temporary stage preceding a normal and permanent condition of statehood. Chief Justice Marshall described the Territories as being "in a state of infancy advancing to manhood, look" ing forward to complete equality so soon as that "state of manhood shall be attained." 2 Chief Justice Taney declared that the power to admit new States authorizes "the acquisition of territory not fit for "admission at the time, but to be admitted as soon "as its population and situation would entitle it to ad"mission." 3 And Mr. Justice Gray has said: "Upon "the acquisition of a Territory by the United States, "whether by cession from one of the States, or by "treaty with a foreign country, or by discovery and "settlement, the same title and dominion passed to

1 U. S. Revised Statutes, $\$ 5570$.

${ }^{2}$ Loughborough $v$. Blake, 5 Wheaton 31 $7,324$.

${ }^{3}$ Scott $v$. Sandford, i9 Howard 393, 447. 
"the United States, for the benefit of the whole "people and in trust for the several States to be "ultimately created out of the Territory." 1

All the land ceded to the United States by the States was transferred upon the understanding that it should be formed, eventually, into States. The Third Article of the Treaty of 1803 , by which France ceded Louisiana, reads: "The inhabitants of the "ceded territory shall be incorporated into the Union "of the United States, and admitted as soon as "possible, according to the principles of the Federal "Constitution, to the enjoyment of all the rights, "advantages, and immunities of citizens of the United "States. . . ." This article was construed by Chief Justice Marshall to mean "that Louisiana shall be "admitted into the Union, as soon as possible, upon "an equal footing with the other States"; ${ }^{2}$ and a like meaning is to be placed upon the Treaty of I 8 I 9 , by which Spain ceded Florida, and the Treaties of 1848 and 1853 , by which Mexico ceded California and New Mexico. With the single exception of Texas, which was annexed by force of a joint resolution admitting it as a State, the vast domain gained by the United States down to I 867 was acquired in trust for States to be subsequently admitted.

The promise of statehood was not expressed in annexing Alaska, Hawaii, and the lately acquired Spanish islands. These omissions are without legal significance, but, excepting the peculiar case of Alaska, an Arctic desert bought to at once oblige a friendly

${ }^{1}$ Shively $v$. Bowlby, I $5^{2}$ U. S. I, 57.

2 New Orleans $v$. De Armas, 9 Peters 224, 235. 
autocrat and bow him out of this hemisphere, they are of deep political import. They mark the first significant refusal to contemplate statehood as the destiny of annexed territory. This refusal is enough of itself to discredit the attempt to connect our acquisitions from Louisiana to the Philippines by a chain of common purpose. In annexing the Philippines we have broken with tradition.

\section{Our Title under the Treaty of Paris}

However the Treaty of Paris should be considered in the light of justice and policy, it expressed the lawful intentions of the signatory powers, and brought the islands under the sovereignty of the United States. And it must be understood that our title to all the land acquired as a result of the war with Spain is derived from Spain exclusively. The President says in his annual message of I899: "The authorities of the "Sulu Islands have accepted the succession of the "United States to the rights of Spain, and our flag "floats over that territory." 1 This statement may convey the wrong impression that our interest in the Sulus differs in derivation and quality from our interest in the rest of the Philippines - in derivation because it is strengthened by the consent of the sultan; in quality, because the statement may imply, what has, indeed, been asserted, that "the rights of "Spain" in the Sulus were those of a protector rather than of a sovereign proprietor.

Now it is true that in 1878 Spain made an agreement with the sultan which perhaps recognizes him 
as the head of a vassal state, and, some months after the ratification of the Treaty of Paris, General Bates was instructed to take this agreement into account in dealing with him. ${ }^{1}$ Then in 1885 Great Britain, Germany, and Spain signed a protocol in which Spanish sovereignty over Sulu was recognized, and Spain agreed to relinquish any claim to territory in Borneo based on the pretensions of the sultan. ${ }^{2}$ But any suggestions of a debased sovereignty in the sultan, perhaps not unlike that attributed to the Indian chiefs, with whom the United States have made treaties, do not qualify the cessionary clauses of the Treaty of Paris; and this is fortunate, because it would be most embarrassing for the United States to claim Sulu by consent of the sultan, when that consent was given in an agreement which Congress has been compelled to treat with contempt because of its qualified recognition of slavery.

The article of cession in the Treaty of Paris was submitted by the American Commission in what proved to be its accepted form, and its precise delimitation of the "Philippine Archipelago" embraced the unmentioned Sulu group. The assertion of the Spanish Commissioners that the "Philippines" did not include the Sulus and the great island of Mindanao was a play for better terms. They said in effect: "You are willing to pay $\$ 20,000,000$ for the “' Philippines.' Here are the 'Philippines'; if you "want Mindanao and the Sulus as well you must pay "more." The American Commissioners replied in

${ }^{1}$ See General Otis's Report for 1899 , pp. I $53^{-1} 5^{6}$.

${ }^{2}$ See Westlake, Chapters on the Principles of International Law, p. 173 . 
effect: "The 'Philippines' we demand, and which "you will cede without change in terms, include Min"danao and the Sulus." Of course the victors proved to be better geographers than the vanquished. Throughout the negotiations Spain's ability to transfer the complete sovereignty of all the land demanded by the United States was never questioned, and in the treaty she assumed to cede, and the United States accepted sovereignty over all. We cannot afford to esteem that sovereignty as less than perfect and all-embracing. We will not go behind the Treaty of Paris for confirmation of our title to any part of the Philippines. As we have not sought "the con"sent of the governed" from the people of Luzon, we cannot even appear to recognize its necessity in dealing with slaveholding and polygamous barbarians who are only restrained from piracy by gunboats and blackmail.

This certificate of title sufficiently demonstrates our legal right to possess the Philippines, and with legal rights only are we at present concerned.

\section{THE EFFECT OF ACQUISITION}

The first question suggested by the cession of the Philippines is whether it has incorporated the islands into the United States.

In some international sense "the United States" defines all the territory in which the Federal Government is responsible before foreign nations. An executive occupation of new-found, or abandoned, or hostile territory will bring it within the international 
boundaries of the United States, because among the nations the state in visible control of a country is accounted its sovereign for important purposes. ${ }^{1}$ But land occupied through enterprise or conquest, unconfirmed by the legislature, does not become part of the United States in a domestic sense, though the act be prompted or approved by the President. The power to enlarge the republic is vested in the treatymaking body and also in Congress, but not in the executive alone. ${ }^{2}$

English law is different. The Crown, having the powers of making war and treaties, is competent to gain territory through their employment, but the land acquired does not become the exclusive dominion of the Crown. In the words of Lord Mansfield, "A "country conquered by the British arms becomes a "dominion of the King in right of his Crown, and "therefore necessarily subject to the legislature, the "Parliament of Great Britain." 3

Whether the new dominion be actually subjected to laws imposed by the Crown, by a local government, or, rarely, by Parliament itself, depends on the will of the latter.

Unquestionably the Philippines are part of the United States in an international sense.

As the seat of a governing community "the "United States" are the States of the Union only.

${ }^{1}$ See Thirty Hogsheads of Sugar $v$. U. S., 9 Cranch 19r, 195; U.S. $v$. Rice, 4 Wheaton 246; Fleming $v$. Page, 9 Howard 603, 6 I 5 .

2 See Fleming $v$. Page, 9 Howard 603, 6r4.

${ }^{3}$ Hall v. Campbell, Cowper 204, 2 I8. See also The Foltina, I Dodson's Admiralty $45^{\circ}$. 
The whole political power of the republic is vested in these forty-five States and their people. The Philippines are no part of this "United States," so there is no reason for the cry of alarm that their incorporation into the territorial body of the republic would mean the admission of millions of Asiatics to the body politic.

There is a third definition of "the United States." As the dominion of a sovereign nation "the United "States" describes a territory larger than the area of the States, but, at present, smaller by the area of Cuba than our "international" territory. This "United States" comprises all the land within the territorial jurisdiction of Congress, and makes one national territory. This definition is repudiated by the Administration, whose attitude toward our new possessions is based on the theory that while the treaty-making body intended to bring, and did bring the islands under the complete sovereignty of the United States, it intended to hold, and did hold them aloof from the United States, except in that international sense which conveys no idea whatever of domestic unity. This theory has been lately approved in one of the circuit courts of the United States. In the court's opinion we read: "The different States " are usually held to be foreign to each other except "as concerns international relations. Sister State "judgments are, for most purposes, foreign judg"ments, and generally for all purposes other than "those specifically mentioned in the Constitution " our States are foreign to each other. On the same "principle Porto Rico remains foreign to the United 
"States except as provided in the Treaty." ${ }^{2}$ Here is a false analogy. The real relation of our States to each other, and the supposed relation of our new possessions to the United States are not referable to "the same principle." The dominion of the republic is platted into political divisions, including Territories, the District of Columbia, and Indian reservations as well as States, and in some respects these are foreign to each other. A corporation, a judgment, a will originating in one of these divisions is foreign in the others: A person charged with crime in one division can be brought back from another only by process of extradition. In this sense the Philippines and Porto Rico are foreign to each other, and to all the remaining divisions. But none of these divisions is foreign before the Federal Government. Even the States which enjoy a measure of sovereignty are not "foreign states"; and a clash of federal and State sovereignties is impossible, theoretically, so accurately is the sphere of each supposed to be defined. Notwithstanding the singular relation of the Indian tribes to our Government, the territory they occupy "is ad" mitted," says Chief Justice Marshall, "to compose a "part of the United States." ${ }^{2}$ Since the political divisions whose people possess some real or shadowy sovereignty are not "foreign" to the United States, how can territory within their exclusive jurisdiction be other than domestic?

The real rationale of the opinion in Goetze $v$. The United States is found in its affirmative answer to what the court says is the sole constitutional ques-

${ }^{1}$ Goetze $v$. U. S., I03 Federal Rep. 72, 83.

${ }^{2}$ Cherokee Nation $v$. Georgia, 5 Peters I, I7. 
tion: "May our Government accept the title of and "sovereignty over territory and at the same time "preserve its status as foreign territory so far as in"ternal relations are concerned?"

The theory that the treaty-making body, or Congress itself for that matter, can extend the complete and exclusive sovereignty of the republic over territory without incorporating it within the national boundaries of the United States lies at the root of the great legal questions of domestic interest suggested by the Treaty of Paris, and it seems to be fostered by the notion that this body has a free hand in the making of territorial arrangements in behalf of the republic. The theory that treaty provisions are a law unto themselves has a certain attraction because engagements with foreign states are presumably sacred; but this ethical principle does not necessarily bind our courts. Should Congress pass an act inconsistent with a treaty pledge a court would enforce the act, and not the treaty, holding simply that an old law had been repealed by a new one. ${ }^{2}$

Another argument for attributing unlimited powers to the treaty-making body is that it must be competent to act quickly and decisively in the most serious emergencies. What agreements and concessions the President and Senate might be forced to make, and the republic be forced to accept by a conqueror, suggests a circumstance too humiliating and too remote to affect the interpretation of their powers in normal cases. And the Treaty of Paris is on our

${ }^{1}$ ro3 Federal Rep. 72, 79.

2 Head-money Cases, I I 2 U. S. 580 ; Fong Yue Ting $v$. U. S., r 49 U. S. 698 ; U. S. v. Old Settlers, 148 U. S. 427. 
part a normal act, requiring no sacrifice of constitutional principle to the law of necessity. The theory of the independence of the treaty-making power finds no place in our jurisprudence. Though the Supreme Court has never been obliged to declare a treaty provision unconstitutional, and would do so with peculiar reluctance, ${ }^{1}$ it holds, as a matter of course, that treaties are subordinate to the Constitution. ${ }^{2}$ " It " need hardly be said," says the Court, " that a treaty "cannot change the Constitution or be held valid if it "be in violation of that instrument. This results from "the nature and fundamental principles of our Gov"ernment." 3 Even in Great Britain it is doubtful whether the courts would respect a treaty provision repugnant to "the law of the land." 4

With the assurance that the treaty-making body, like Congress, is bound to respect the organic law which created it, we proceed to examine the particular assertion that while the Treaty of Paris effects a complete transfer of the sovereignty of the Philippines from Spain to the United States, the presence of certain clauses and the absence of others forbid the conclusion that the Archipelago is incorporated

${ }^{1}$ See Ware $v$. Hylton, 3 Dallas $199,237$.

${ }^{2}$ See U. S. $v$. The Peggy, I Cranch ıо3, 1 го; New Orleans $v$. U. S., 10 Peters 662, 736; Lattimer $v$. Poteet, 14 Peters 414; Doe $v$. Braden, 16 Howard 635, 657; Geofroy $v$. Riggs, 133 U. S. 267 ; Thomas $v$. Gay, 169 U. S. 264, 271 ; License Cases, 5 Howard 504, 613.

${ }^{3}$ The Cherokee Tobacco, in Wallace 6r6, 620.

${ }^{4}$ See The Parlement Belge, 4 P. D. 129,5 P. D. (C. A.) 197; Walker v. Baird, [1892] A. C. 49r; Dicey, Law of the Constitution, Ist Ed. 39 I. 
in the United States, and leave it a foreign country in respect of the internal administration and policy of the republic.

The Fourth Article of the Treaty reads: "The "United States will, for the term of ten years from "the date of the exchange of the ratifications of the "present treaty, admit Spanish ships and merchan"dise to the ports of the Philippine Islands on the "same terms as ships and merchandise of the United "States." It is argued that this trade privilege could not be accorded in a part of the United States, because of the prescription of uniformity of duties "throughout the United States," and therefore that its appearance in a treaty is proof that the islands have not been incorporated. This argument puts the cart before the horse. Whether the Philippines are incorporated depends altogether upon the legal effect of the cession of sovereignty - a principal part of the treaty wholly unaffected by this subsidiary clause, which, if incompatible with the consequence of cession, may be declared invalid by our courts in a proper suit. Treaties, like statutes, are to be construed so that, if possible, all their parts shall stand; but if this subsidiary provision be declared unconstitutional by the courts it will be excised without damage to the remainder. If this trading privilege be illegal, its excision would not operate to retrocede the islands to Spain, nor to alter the title by which we hold them. The agreement is a condition subsequent to cession, and non-performance, whether through perversity or constitutional inability, would only give Spain a grievance.

The Ninth Article declares that "the political 
"status and civil rights of the native inhabitants of "the territories hereby ceded to the United States "shall be determined by the Congress." This singular declaration is supposed to negative the idea of an incorporation of territory. Says the Court in the Goetze case: " "If this treaty must be so construed "that the territory is incorporated into the United "States, while the inhabitants are denied the polit"ical status and civil rights of citizens, the treaty "must be declared unconstitutional, and in that case "Porto Rico [and of course the Philippines] remains "a foreign country." This cannot be true. It is incredible that a judicial annulment of this clause, as being inconsistent with an incorporation inferred from an accepted cession, should invalidate the cession itself, and leave the United States in wrongful possession of a foreign land on the theory that, by this reservation, they had disabled themselves from accepting the inevitable consequences of a rightful possession. The truth is that the real position of a subsidiary clause is again exaggerated, and with less excuse, if possible, than in the case of the commercial privilege just mentioned. For this privilege, being a contract with Spain and, presumably, part consideration for cession, has so peculiar a claim upon our national honor that its rescission, even on the score of unconstitutionality, would place us in a disadvantageous light. But the declaration is not a contract with any one-not even a promise. It is merely a reservation of a matter of domestic interest for the determination of Congress, and its qualification or annulment by the Supreme Court would simply illustrate the rule $1_{\text {I }} 3$ Federal Rep. 72, 83. 
that treaties must first conform to the Constitution, and then, if possible, to the expectations of their makers - a rule kept in mind by our Peace Commission, whose president has said in explanation of this reservation: "It was thus undertaken to give Con"gress, as far as the same could be constitutionally "done, a free hand in dealing with these new "territories and their inhabitants." 1

The Ninth Article of the treaty declares also that the Spanish-born residents of the ceded and relinquished territories, who shall not have elected to retain their old allegiance within a given time, shall be deemed to have adopted "the nationality of the ter"ritory in which they may reside." Does this impress the Philippines and Porto Rico with nationalities distinguished from the nationality of the United States? The "nationality" attributed to the "relin"quished" island of Cuba has no bearing on this question. It is anomalous, like everything relating to the status of this oddly situated island. Quite different is the "nationality" of the ceded territories, for these being duly transferred from one sovereign to another, their character is determinable by simple principles; and in applying them we are not embarrassed by the variant conceptions of "nationality" in its relation to people. ${ }^{2}$

The national territory prefigured by the Article

${ }^{1}$ Address of Hon. William R. Day before the Michigan Bar Association, May 23, 1900, p. 9. (The italics are mine.)

${ }^{2}$ See Boyd's Wheaton, International Law, 3 d Ed. 30 ; Maine, Early History of Institutions, 74; Savigny, Conflict of Laws, Guthrie's translation, 2d Ed. 58; Tupper, Our Indian Protectorate, 393; Cogordon, La Nationalité, 2d Ed. 3-6. 
can be nothing else than land belonging to a state, and when I assert that we have only to name the state which is the sovereign proprietor of the soil in order to name its nationality, I rely upon a rule of public law never questioned in our courts, and generally accepted in other countries.

"Her Majesty's dominions," is the legal description of that empire which comprises the British Islands, British India, and the colonies of every description, and every part of these dominions is British territory. Commenting on an act of Parliament referring to "foreign dominions" of the Crown, Chief Justice Cockburn said: "I understand "the term 'foreign dominion' to mean a country " which at some time formed part of the dominions of " a foreign state or potentate, but which by conquest "or cession has become part of the dominions of the "Crown of England"; and Justice Blackburn concurred in this opinion. ${ }^{1}$ An Englishman would ridicule the notion that any part of the Queen's dominions could be other than British territory. Even Australia and Canada, so nearly independent in fact, have no nationality of their own. When France formally extends her sovereignty over new territory she does not amuse herself by pretending that it has a nationality other than French. After the acquisition of Madagascar, $M$. Hanotaux said in the Chamber of Deputies, "Madagascar is French "territory." 2

To give the clause in question a constitutional, even an every-day meaning, it must be under-

1 Brown's Case, 5 Best and Smith 280, 290.

2 L'Année Politique (1897), 96. 
stood to attribute the nationality of the United States to Philippine and Porto Rican territory: And how can land be "foreign" to that country to which it is linked by the tie of nationality?

The Treaty of Paris contains no express declaration that the ceded islands are incorporated into the United States. Nor do we find any of those clauses recognizing citizenship, promising statehood, or delimiting new national boundaries which appear in some earlier treaties of annexation. But these omissions are, like certain subordinate clauses, incompetent to qualify the legal effect of these masterwords of the treaty: "Spain cedes to the United "States the archipelago known as the Philippine "Islands," and "cedes" her "sovereignty" thereof; and Porto Rico is transferred in similar terms. By ratifying this treaty the United States have accepted completely the sovereignty of the islands, as I understand the law of the matter; but if the assent of the House of Representatives be really essential to a perfect acceptance, as some members asserted in a debate on the Alaska purchase, it has been given by the appropriation of $\$ 20,000,000$ to carry out the treaty, or if this payment bound the House in regard to the Philippines only, the House has certainly accepted Porto Rico by legislating for it. Add that the United States are in possession, and it is plain that the combination of law and fact impresses upon the islands the nationality of our republic. None other would be compatible with our sovereignty.

Commenting on an earlier annexation like unto this one in its legal aspects, Chief Justice Marshall said: 
"The usage of the world is, if a nation be not en" tirely subdued, to consider the holding of conquered "territory as a mere military occupation until its "fate shall be determined at the treaty of peace. If "it be ceded by the treaty, the acquisition is con"firmed, and the ceded territory becomes a part of the " nation to which it is annexed; either on the.terms "stipulated in the treaty of cession, or on such as its "new master shall impose." 1

The important phrase of this statement is, "the " ceded territory becomes a part of the nation to which "it is annexed." The additional words, "either on "the terms stipulated in the treaty, or on such as its " new master shall impose," do not, as some suppose, suggest the uncertainty of incorporation, for the fact of incorporation is established by the accepted cession; they merely note circumstances that may accompany or follow incorporation. The "new mas" ter" may impose upon its possessions any terms, that is to say, any laws permitted by its own institutions. Articles of cession may contain stipulations, but after the cession is executed non-performance of the stipulations will not affect the title of the acquiring state in its own courts. For example, when we acquired California we agreed to pay Mexico $\$ 3$, 000,000 on the ratification of the treaty, and $\$ 12,000,000$ in annual instalments of $\$ 3,000,000$, but a default in the payments would not have affected the incorporation of California into the United States; indeed, California became a State of the Union before all the instalments were due.

${ }^{1}$ American Insurance Co. $v$. Canter, I Peters 5 II, 542. (The italics are mine.) 
The rule that ceded land is incorporated into the domestic territory of the acquiring state is a consequence of the fact that it falls at once within the territorial jurisdiction of the legislature, and all land coming under this jurisdiction through agreement or conquest or occupation, through fair means or foul, becomes an integral part of the acquiring state because of its subjection to the sovereign body that makes the laws. "What, then, is the "extent of jurisdiction which a State possesses?" says Chief Justice Marshall. "We answer, without "hesitation, the jurisdiction of a State is coextensive "with its territory; coextensive with its legislative "power": ${ }^{1}$ And Mr. Justice Story said: "The laws "of no nation can justly extend beyond its own "territories, except so far as regards its own citi"zens." ${ }^{2}$ In the Goetze case Porto Rico is called a "foreign country," ${ }^{3}$ yet is recognized as being within the full jurisdiction of the Federal Government. But because it is within this jurisdiction it cannot be "foreign."

There are, indeed, instances of the subjection of two countries to one sovereign, but these are not in point. Leopold II is King of the Belgians; he is also sovereign of the Congo State. William IV was King of Hanover as well as of Great Britain, and it is noteworthy that, while there was no fusion of states, ${ }^{4} \mathrm{Han}$ overians in England appear to have been British subjects by virtue of their allegiance to the person who

1 U. S. v. Bevans, 3 Wheaton $33^{6,} 3^{86 .}$

2 The Apollon, 9 Wheaton 362, 370 .

${ }^{3}$ 103 Federal Rep. 72, 77.

4 See Lewis, Government of Dependencies, Lucas's Ed. 90. 
happened to be King of Great Britain. ${ }^{1}$ The union in these and similar cases is wholly personal, in no wise resulting from any connection between the states themselves. William was King of Hanover by descent from that Elector of Lüneburg who was called to the English throne as George I (the electorate having been made a kingdom in 1814 ), not because he was King of Great Britain; and the reason why Queen Victoria did not reign in Hanover was because there females are barred from the succession. Leopold is sovereign of the Congo State by special arrangement, not because he is King of the Belgians; and it appears that he may devise his African estate by will. ${ }^{2}$

No one will pretend that the United States and the Philippines are two countries linked in a personal union by virtue of one man being the chief magistrate of each. Such a pretense would ignore the fact that our President governs the islands solely as the chief magistrate of the United States. Besides, the President would seem to be constitutionally incapable of exercising a personal and detached sovereignty in another country, whether opportunity should come through invitation, inheritance, or conquest: And this principle is not violated in Cuba, where the President governs as the commander-inchief of our forces in military occupation of a foreign land. The theory that Congress and the President may together govern our new possessions as foreign countries is also erroneous. The powers granted to Congress, and it has no others, are conferred for

${ }^{1}$ Stepney Election Case, L. R. I 7 Q. B. D. 54. See Calvin's Case, Coke's Rep. vii, $x$, on the Union between England and Scotland.

2 Blanchard, L' État Indépendent du Congo, 232. 
the governing of the United States, and not of any foreign land. It is "a Congress of the United "States," not of the United States, and of Porto Rico, and of the Philippines, and of any other country we may wish to exploit without troubling ourselves about national unity and equal rights. "By the "Constitution," says the Supreme Court, "a gov"ernment is ordained and established for the United "States of America, and not for countries outside "of their limits." 1

In the Goetze case the Court seeks to discredit an incorporation of Porto Rico into the United States by asserting that it would disable us from according to that island (and of course to the Philippines) the practical independence which, in the latter country at least, is desired so ardently by the inhabitants. "If "we cannot hold ceded territory without bringing it "under the Constitution, as an integral part of the "United States," says the Court, "then we cannot "give to Porto Rico practical independence,- - a con"stitution and laws of her own, taxes of her own, and "hold merely the sovereignty, confined, perhaps, to "control of foreign relations. If Porto Rico is still a "foreign country, we might adopt that course." ${ }^{2}$

This statement seems to contemplate a protectorate, and the embarrassments it suggests are purely imaginary. If the Court means that territory once incorporated can never be handed over to its inhabitants, it ignores the cessionary powers of the United States. If the Court means that Congress may maintain a protected state within the limits of its jurisdiction, it

${ }^{1}$ Ross's Case, r $4 \circ$ U. S. 453,464 .

2 I03 Federal Rep. 72, 82. 
mistakes the nature of the true protectoral relation, for it appears that in theory of law a protected state is usually deemed to lie beyond the jurisdiction of the legislature of the protecting state, whose interests are managed by its executive department acting in the domain of foreign relations. ${ }^{1}$

What the United States might have done in the Philippines by way of a protectorate is now a belated question. What they may do yet, we shall consider later. ${ }^{2}$ At present we are concerned to know only that they have brought the islands within the jurisdiction of Congress: And no argument of inconvenience is strong enough to overcome the conclusion that land thus brought within the complete and exclusive sovereignty of our legislature cannot be a foreign country, but must be part of the United States by force of the supreme tenure by which it is held.

The Philippines are not only within the United States in a general sense ; they are not distinguished organically from the rest of our territory. Prior to the Treaty of Paris the common property of the States of the Union, called the territory of the United States, comprised New Mexico, Arizona, Oklahoma, Indian Territory, Alaska, Hawaii, and a number of islets. To these are now added the Philippines, Porto Rico, and Guam.

These several districts present different character-

${ }^{1}$ See Lee-Warner, The Protected Princes of India, 18r, 249, 263 , 333. Compare Ilbert, The Government of India, 440 , note 3 , on the West African protectorates.

${ }^{2}$ See Chapter V. 
istics. All are not governed in the same way. Some will become States or parts of States; others will not. Some, indeed, have been acquired under what has been called a promise of ultimate statehood, ${ }^{1}$ but these are not distinguishable in law from the others, for the admission of a new State is an act of policy within the unlimited discretion of Congress. Hawaii, annexed without promise, may enter the Union before Indian Territory, carved out of that Louisiana purchase in regard to which the promise was made nearly a century ago. All are held by the United States in sovereign proprietorship, and although we unite now in protesting the everlasting unfitness of the Philippines for admission to the Union, our prejudice does not prevent their being, in point of law, as eligible as New Mexico, nor would their admission by the next generation involve a more radical and surprising reversal of prejudice than the admission of millions of negroes to political equality by the last generation. All the districts I have named are organically alike, because each is owned by the United States in sovereign proprietorship, and when this likeness is determined all differences in condition, location, and probable destiny must be purely circumstantial.

${ }^{1}$ See New Orleans $v$. De Armas, 9 Peters 224, 235. 


\title{
CHAPTER II
}

\section{THE CONSTITUTION AND THE PHILIPPINES}

\author{
ARGUMENTS AGAINST THE RULE OF THE \\ CONSTITUTION EXAMINED
}

An anxiety to rule the Philippines free from constitutional restrictions is even more marked than the unwillingness to consider them as part of the United States. Indeed, this unwillingness is due to the apprehension that throughout all this territory the Constitution must be the supreme law; and there is so keen a fear that we shall be obliged to administer the Philippines by constitutional rules that ingenious arguments are advanced to prove that the Constitution is really quite as foreign to these islands, unquestionably ours, as though they belonged to another nation.

Prominent among the arguments are these: that the Constitution is not self-extending; that it is ineffective beyond the North American continent; that it was ordained for the States alone; that the power of the United States over annexed territory is the same as that possessed by other nations.

\section{That the Constitution is Not Self-extending}

It has been contended that the Constitution is not in the Philippines because it has not been carried there 
by an act of Congress. This argument attributes unlawful powers to the federal legislature. Congress is the creature of the Constitution, not its master; and is bound to obey it wherever it is supreme, not privileged to decide where, within the jurisdiction of the United States, it shall be supreme. Probably the argument is suggested by an improper estimate of legislative practice. Certain acts of Congress organizing Territories enact the law of the Constitution for the new district. The Supreme Court has recognized such legislation, but has never treated it as carrying the Constitution to a new field. When Congress authorizes a territorial legislature to make laws "not inconsistent with the Constitution and "laws of the United States," it affirms " a condition " necessarily existing in the absence of express dec"laration to that effect." 1 The acts in question are not of constitutional dignity. If the Constitution is in the territory by its own force they affirm an actual condition in a spirit of abundant caution; if it is not, they are merely repealable laws couched in the phrase of the Constitution, and Congress could withdraw any privilege granted by the so-called extension of the Constitution. Of all the heresies that embarrass the fair discussion of the Philippine question few are more mischievous than the notion that Congress is competent to grant and, if to grant, to take away or withhold the Constitution at pleasure. And the President and Senate, acting as a treatymaking body, are quite as incompetent to play with the organic law from which their existence and their powers are derived.

${ }^{1}$ Maynard $v$. Hill, 25 U.S. $190,204$. 
Mr. Webster said in the Senate on February 24, I 849: "I do not say that while we sit here to make "laws for these Territories we are not bound by "every one of the great principles which are in"tended as general securities for public liberty. But "they do not exist in Territories till introduced by "the authority of Congress." 1- Hence the suggestion that the Constitution will not be effective in the Philippines until Congress shall legislate for them. This suggestion is wholly impracticable, whether it be predicated upon casual enactments, or upon a statute establishing a civil government. Even Webster's name cannot dignify the proposition that constitutional guaranties demand respect only when the establishment of civil order under the auspices of Congress renders them less likely to be needed. A monstrous doctrine indeed that the President may lawfully rule United States territory during the inaction of Congress free from the restraints which, it is conceded, affect both himself and Congress after the territory shall have been duly organized! Even a King of England cannot do so much, for as Lord Mansfield said: "If the King (and when I say the "King I always mean the King without the concur"rence of Parliament) has a power to alter the old "and to introduce new laws in a conquered country, "this legislation being subordinate, that is, subor"dinate to his own authority in Parliament, he "cannot make any new change contrary to funda"mental principles."

It is noteworthy that they who deny, consistently,

${ }^{1}$ Curtis's Life of Webster, ii, 366 .

${ }^{2}$ Campbell v. Hall, Cowper 204, 209. 
the efficiency of the Constitution in our new possessions still maintain this opinion in regard to Porto Rico, although Congress has prescribed a government for it. Indeed, parts of the Porto Rico Government Act itself contemplate the exclusion of the Constitution from the island.

The foregoing arguments proceed upon the theory that the Constitution can have no expansive force of its own, but, like the generality of statute law, must gain efficiency in annexed territory through some act supplementary to the act of annexation. This theory is unsound. The range of the Constitution is not a political question, determinable by the President or Congress. These servants of the Constitution cannot decide in what circumstances or places its rules shall bind them. The range of the Constitution is a judicial question, determinable by construction of the instrument, and, did it not broaden with the expansion of the United States, nothing but an amendment could extend it beyond their original boundaries, except, perhaps, the admission of a new State.

The theory that the Constitution has a force of its own is, of course, subordinate to the primary consideration that a living constitution presupposes a living government. The Constitution framed by our Federal Convention could not vitalize itself. It was an abstraction until the States launched the government it contemplated, but then it became the inspiration and the guide of this government.

The theory of the self-extending force of certain provisions of the Constitution must be distinguished from a question of constitutional construction which, 
sometimes, has been supposed to discredit it ; ${ }^{1}$ namely, whether a provision be so phrased as to require legislative action to make it efficient anywhere. To illustrate the distinction between this question and the theory of self-extension, and also a divergence of opinion in answering the question, I cite a once famous disagreement between federal and State courts. The Constitution of the State of Mississippi, adopted in I 832, contained this provision: "The introduction "of slaves into this State as merchandise, or for sale, "shall be prohibited from and after the first day of "May, 1833." The Supreme Court of the United States decided that the provision did not execute itself, but required action by the legislature, especially the imposition of penalties for violation, before it should become effective. ${ }^{2}$ The State court, however, refused to follow the Supreme Court. It declared the provision to be self-executing, upon the following theory of constitutional obligation: The Constitution, said the Court, "is but the frame or skeleton "of a government, containing the general outline, "leaving the detail to be filled up in subordination " and auxiliary to the essential and fundamental prin"ciples thereby established. But it is not on that "account the less binding. It is from its very nature "and object the supreme law of the land, fixed and " unalterable, except by the power that made it. It "contains only certain great principles which are to "control in all legislation, and extend through the "whole body politic. These principles are of them"selves laws. Constitutions do not usually profess

${ }^{1}$ See Benton, Thirty Years' View, II, p. 7 I 4.

${ }^{2}$ Groves $v$. Slaughter, ${ }_{5}$ Peters 449. 
"to insure obedience by prescribing penalties; they " merely declare the rule or establish the principle, "which, being paramount, makes void whatever is "repugnant to it. Its mandates or principles bind " by a moral power. . . General principles, thought " to be essential to a free government, are declared; "and (emanating from the sovereign authority) that "mere declaration imparts to them all the force of a "supreme law."

We are not concerned with the merits of this disagreement, though I think the State court was in the right. At all events, its masterly exposition of the obligatory force of constitutional principles generally is especially applicable to the Federal Constitution, whose principles, with few exceptions, do not belong in the second-rate class of recommendations depending for obligation upon the pleasure of the legislature, but are themselves laws enforcible by the courts.

\section{That the Constitution is not Effective Beyond the North American Continent}

In the annual report of the Secretary of War for I 899 we read: "The people of the islands have no "right . . . to assert a legal right under the pro"visions of the Constitution, which was established "for the people of the United States themselves, and "to meet the conditions existing upon this continent"; and, further, that the Porto Ricans cannot demand that tariff duties shall be uniform throughout Porto Rico and our mainland, because the constitutional provision of uniformity was "solely adapted to the

${ }^{1}$ Brien $v$. Williamson, 8 Mississippi $\mathbf{4} 4$, 7 . 
"conditions existing in the United States upon the "continent of North America." In other words, the Constitution is supposed to have been ordained for the present and future dominions of the United States upon the continent of North America, and nowhere else. The Preamble, it is true, entitles our republic “The United States of America," but I understand the suffix to be merely a descriptive term aptly chosen at the time, and not a legal restriction; otherwise we could not have lawfully annexed the Philippines. This "continental" theory is not even derived from the Preamble, for it restricts the Constitution to North America. Upon what basis of fact is a Constitution conceded to be adapted to the diverse physical, social, and economic conditions of our continental domain deemed to be essentially unfit for Porto Rico? Upon what principle of law can there be read into the Constitution this, or any other purely geographical limitation on its authority?

\section{That the Constitution was Ordained for the States Alone}

The most specious argument against the rule of the Constitution in the Philippines is that it was ordained for the States of the Union alone.

This proposition was advanced in the debates in Congress on the acquisition of Louisiana in 1803 , and on the question of slavery in California in 1849 ; it has been resurrected in recent discussions; but it has never gained even the consideration that the common assent of statesmen might give it before the courts.

1 The italics are mine. 
The proposition lacks the support of precedent. If the theory that the Constitution is operative in the States only has been consciously applied in administering outlying territory its applications have been infrequent and, presumably, inexcusable. There is no warrant for the boast that in denying the Constitution to our new possessions the Administration adds weight to a practical construction of the organic law which the courts should respect.

The present policy of definitely excluding new territory from the great customs district of the republic violates precedent. ${ }^{1}$

Regarding the general guaranties of the Constitution in annexed territory, we find that in the case of Louisiana while the inhabitants complained that selfgovernment was not accorded at once, and that American rulers did not understand the local laws they were expected to administer, our government did not deny the efficacy of the guaranties, and the Supreme Court practically recognized their obligation in Bollman's case. ${ }^{2}$

General Wilkinson arrested Bollman in Orleans Territory (Louisiana) upon a charge of treason, and sent him to Washington for trial, all without civil warrant: The Supreme Court discharged him; and Judge Story termed the arrest "a very gross violation of the Fourth Amendment." 3

Whatever we did in Florida before we took possession under the completed treaty of cession was done in a foreign land, and so is immaterial to this inquiry. After the cession General Jackson was com-

1 See infra, p. 79.

${ }^{3}$ Commentaries, Sec. I902, Note.

${ }^{2} 4$ Cranch 75 . 
missioned, by the authority of Congress, "with all " the powers and authorities" theretofore enjoyed by the Spanish rulers. ${ }^{1}$ Jackson was not affected, however, with a Spanish officer's irresponsibility in regard to our Constitution, ${ }^{2}$ though he is said to have declared that his powers were those " that no one under " a republic ought to possess "; ${ }^{3}$ and if during his brief term he was justly chargeable with arbitrary actions, they are not evidence of a general policy.

The obligatory force of the Constitution in California was maintained by Polk's Administration, whose position was attacked by Webster and Benton because Calhoun assumed that it secured the right to take slaves into the new Territory. If Calhoun argued for the Constitution in California with the expectation of extending the area of slavery, he at least contemplated the attribution of its rights to white men, while these rights are now withheld from all people in the islands.

I am not aware of any act of the Government denying the authority of the Constitution in Alaska.

A keen search for arbitrary acts of the Federal Government in unorganized territory, or, for that matter, in the States, may not be wholly unsuccessful; but the search is a discreditable waste of time when its purpose is to parade them for our commendation. Such acts are transgressions against the republic, and their approbation as standards of conduct is a repulsive feature of the attack now being made upon constitutional government.

${ }^{1} 2$ I Niles Weekly Register 135.

${ }^{2}$ See the citation from Pollard $v$. Hagan, infra, p. ${ }^{3} \mathbf{1}$.

${ }^{3} 2$ I Niles Weekly Register ${ }^{3} 6$. 
Replying to the assertion that the theory of the restriction of the Constitution to the States has the sanction of judicial opinion, I am justified in stating that it is not encouraged by a single dictum of the Supreme Court, hardly countenanced, indeed, by a questioning phrase, and has been repeatedly discredited in that seat of authority. ${ }^{1}$

In Callan $v$. Wilson, the Supreme Court maintained the law of the Constitution beyond the States in the only case where an act of Congress disregarding it was forced upon the Court's attention. The suggestion that the principle of this decision is limited to the District of Columbia, to which the act applied, is refuted in the following paragraph of the opinion: "In Reynolds $v$. United States, 98 U. S. I45, "I 54, it was taken for granted that the Sixth "Amendment of the Constitution secured to the "people of the Territories the right of trial by jury " in criminal prosecutions; and it had been previ"ously held in Webster v. Reid, I I Howard 437, " 460, that the Seventh Amendment secured to them "a like right in civil actions at common law. ${ }^{2} \mathrm{We}$ " cannot think that the people of this District have, in "that regard, less rights than those accorded to the "people of the Territories of the United States." ${ }^{3}$ The notion that, because the District of Columbia once belonged to States which ceded it for a Federal

${ }^{1}$ See also the opinion of Lochren, District Judge, in Ex parte Ortiz, roo Federal Rep. 955.

${ }^{2}$ See also American Publishing Co. v. Fisher, r66 U. S. 464; Springville $v$. Thomas, 166 U. S. 707 ; Thompson $v$. Utah, 170 U. S. 343 ; National Bank v. Guthrie, 173 U. S. 528, 537 ; Black v. Jackson, 177 U. S. 349,363 .

${ }^{3}$ Callan $v$. Wilson, 127 U. S. $540,55^{\circ}$. 
capital, its people enjoy constitutional rights denied to the people of the Territories is quite as fanciful as the conceit of the early days of the Civil War, that if Maryland should secede she would carry the Federal capital with her by operation of law! If the District is held by the United States subject to a possibility of reverter for condition broken, it is too remote to affect the status of the inhabitants. There is no reason of policy why they should be preferred to the people of Oklahoma, nor any of constitutional law, for, as Chief Justice Marshall says, the District and a Territory " may differ in many respects, but neither "of them is a State, in the sense in which that term "is used in the Constitution." ${ }^{1}$ Each has been called a state, however, in the primitive sense of being an organized community, ${ }^{2}$ and each has been ranked among the States of the Union in order to effectuate a treaty pledge. ${ }^{3}$

Territories have been also described as "depen"dencies," ${ }^{4}$ perhaps not an inaccurate description of districts whose communities lack all attributes of sovereignty. With better reason they are likened to the counties of a State, ${ }^{5}$ and to "organized munici"palities," 6 and it is quite as impossible for the republic, as for a State, to withhold from the subordinate districts within its domain the protection of its Constitution.

1 New Orleans $v$. Winter, I Wheaton 9r, 94 .

2 Talbott $v$. Silver Bow County, I 39 U. S. $438,448$.

${ }^{3}$ Geofroy $v$. Riggs, 133 U. S. 258.

${ }^{4}$ Snow $v$. U. S., 18 Wallace $317,320$.

5 National Bank $v$. County of Yankton, ror U. S. I 29, I 33.

${ }^{6}$ Geofroy $v$. Riggs, I 33 U. S. $25^{8}, 268$; see also Utter 2 '. Franklin, $1_{72}$ U.S. 416,423 . 
Among the Justices who have recognized the Constitution as having a broader dominion than the States are Chief Justices Marshall, ${ }^{1}$ Taney, ${ }^{2}$ Waite, ${ }^{3}$ and Fuller, ${ }^{4}$ and Justices Curtis, ${ }^{5}$ Miller, ${ }^{6}$ Bradley, ${ }^{7}$ Harlan, ${ }^{8}$ Matthews, ${ }^{9}$ Gray, ${ }^{10}$ Brewer, ${ }^{11}$ Field, ${ }^{12}$ and Clifford. ${ }^{13}$ This consensus of opinion represents every theory of constitutional interpretation that has been expounded in the Supreme Court.

Several decisions cited in opposition are readily distinguished. In Benner $v$. Porter,${ }^{14}$ the Court held that territorial courts are not courts of the United States within the meaning of the judiciary clauses of the Constitution. This decision simply affirms the absolute discretion of Congress in creating the machinery of territorial government. The Mormon Church case ${ }^{15}$ involved an act of Congress applying to educational uses certain property of the dissolved Corporation of Latter-day Saints in Utah Territory.

${ }^{1}$ Loughborough $v$. Blake, 5 Wheaton 317,324 .

${ }^{2}$ Strader $v$. Graham, ro Howard 82, 96 ; Scott $v$. Sandford, 19 Howard 393, 449.

${ }^{3}$ National Bank $\%$. County of Yankton, Ior U. S. ז 29, I33.

${ }^{4}$ Mormon Church v. U. S., I 36 U. S. I, 67.

${ }^{5}$ Scott $v$. Sandford, I9 Howard 393, 614, 624 .

${ }^{6}$ Slaughter-house Cases, 16 Wallace $36,72$.

${ }^{7}$ Mormon Church v. U. S., 136 U. S. I, 44.

${ }^{8}$ McAllister $v$. U. S., I4I U. S. I 74, I 88.

${ }^{9}$ Murphy $v$. Ramsey, I $4_{4}$ U. S. I $5,44$.

${ }^{10}$ Capital Traction Co. v. Hof., 174 U. S. x.

${ }^{11}$ Fong Yue Ting $v$. U. S., I49 U. S. 628.

${ }^{12}$ Maynard v. Hill, I 25 U. S. 190, 204.

13 "The City of Panama," гог U. S. $453,460$.

${ }^{14} 9$ Howard, 242.

${ }^{15} \mathrm{I} 36$ U. S. $\mathrm{x}$. 
Three Justices declared the act to be invalid because spoliative, thus affirming their conviction of the authority of the Constitution in the Territory. The Court recognized the obligation of the constitutional guaranties in Utah, but held that the disposition of the property was justified by the law of charitable uses. In Ross's case, ${ }^{1}$ the petitioner had been convicted of murder before our consular court in Japan. The conviction was affirmed, though the act of Congress authorizing the court under a treaty with Japan did not provide for presentment and trial by jury. The judge of the court was an American, yet it was not, from the constitutional standpoint, essentially different from a tribunal of mixed nationality like the one in Egypt, and in either case there is no question of carrying our Constitution to a foreign land, where, as the Supreme Court said, "it can have no opera"tion." Usually, such tribunals are created for the protection of Christians in non-Christian countries. As they exist, in theory of law, by the permission of the local sovereign, albeit the permission is commonly extorted, their jurisdiction is entirely a matter of arrangement. As they dispense justice in a strange environment, their procedure is largely a matter of discretion. Our former privilege in Japan does not interpret our present duty in the Philippines; for we claim territorial sovereignty over the islands, not extraterritorial privilege, the whole authority of the United States, not a fragment of authority wrung from a foreign government.

The textual criticism by which territory beyond ${ }^{1}$ I 40 U. S. 453 . 
the States is read out of the Constitution, upon the theory that the "United States" covered by the Constitution comprises the States of the Union alone, is as harsh and artificial as that of the most strict constructionists of the old school, whom the new school resembles in denying the national and commercial unity of all who owe allegiance to the republic. And the new school is subject to a reproach not imputable to the old: It reverses the great rule of the common law by making every presumption against the individual and in favor of the state, for it attributes to the Federal Government absolute dominion over all persons and property lying beyond what it is pleased to call the "United "States" of the Constitution. The "United States," whose people framed the Constitution, and retained for themselves and the States all powers not delegated to the Federal Government are, unquestionably, the States of the Union only. These States and their people wield the whole political power of the republic. $^{1}$ Unquestionably the Constitution contains clauses relating exclusively to the States either in terms or by necessary implication. Other clauses embody principles of universal value and unrestricted range, and these are operative throughout the larger "United States" described by Marshall as " our great republic, which is composed of States and "Territories. The District of Columbia, or the Terri"tory west of the Missouri, is not less within the "United States, than Maryland or Pennsylvania." 2

1 See infra, p. 70.

${ }^{2}$ Loughborough $v$. Blake, 5 Wheaton $3^{1} 7,3^{1} 9$. 
That the Power of the United States over Annexed Territory is the Same as that Possessed by Other Nations

The most popular argument for withholding the Constitution from the Philippines is that the United States are equal to any other nation in power and resource, and, therefore, are competent to deal with the islands as another nation might under the circumstances. Deferring to this opinion for the moment, let us inquire whether nations whose rank and experience invite, apparently, our profitable study of their expansion policies are accustomed to do what we are urged to do ; namely, to divide national territory into sections distinguished organically by the presence of effective constitutional restraints on governmental power in the one, and the absence of such restraints in the other.

The colonial policies of Germany, Italy, and Japan are in the experimental stage; and we shall not find a model in the exploitation of Java by Holland.

Constitutional questions, in the Western sense, are practically unknown in Russia, whose inhabitants are classified as the Czar - and the others. Each acquisition of territory means simply the enlargement of the Czar's dominions and the increase of his subjects.

The first French republic professed to carry the French ideals of liberty, equality, and fraternity to its neighbors in Europe, and the present republic affects the same office in its colonies. It is not material to determine the value of these ideals, or how nearly they are realized. It is sufficient for our 
purpose to know that the French Constitution is not restricted, in theory, to France in Europe. And Algeria, French India, Mauritius, Réunion, and Guadeloupe, in sending senators and deputies to the national legislature, enjoy political rights denied to the colonies of Great Britain and the territories of the United States.

The colonial policy of Great Britain is especially commended for our imitation, but it will appear that organic equality is the constitutional theory in the British Empire, and not discrimination. For the will of Parliament is the organic law of the British Empire, whose parts are united by their common subjection to it, and Parliament presides over the scattered lands and the polyglot people with equal and unfettered power. England and the Gold Coast are integral parts of this empire: ${ }^{1}$ The citizen of London and the native of India are on an equal footing before an authority that acknowledges no legal constraint. The opportunist colonial policy so cleverly displayed in the administration of the Queen's dominions beyond the sea is but a manifestation of a force quite as supreme in the British Islands. The organic law of the United States is the written Constitution, and so long as its broad guaranties run throughout the national territories all the people are equal before the law - an equality in harmony with the British theory. But were these guaranties circumscribed, all would not be equal; there would be the law of the Constitution for some, the pleasure of Congress for others - an inequality in marked contrast to the British theory. 
Our survey of foreign policy is of some practical interest inasmuch as it shows that the subjection of our new possessions to the organic law is not in line with the best precedents, but, more importantly, it should remind us how radically our government differs from the governments of Europe, including that of Great Britain. The assertion that the American people are a nation like the people of the British Empire is true in the sense that there is an ultimate authority in the republic substantially similar to that of the British nation. It is false in the suggested sense that this authority is lodged in Congress. Parliament is the British nation for every purpose. Congress is the American nation only for the purpose of exercising the powers delegated in the Constitution, and a brief consideration of the meaning and office of this Constitution will demonstrate the incompetency of Congress to rule territory in disregard of its provisions.

The Constitution is the foundation of the United States. Destroy it, and the United States would disappear,- the name and the thing alike,-leaving forty-five sovereign States, each entitled to a share in outlying territory. "The United States of America" is, in short, an artificial name given by the written law which created the thing it describes. This identification of our Constitution with our country is strikingly illustrated in the phrasing of the constitutional oath of office. It is customary in all countries to require of officials a formal profession of fidelity to the state they serve, and this is made to the person or thing that in local usage most closely represents the state. In accordance with this custom, 
every official in the United States, from the President down, is bound by oath or affirmation to support the Constitution, and only the Constitution. And it is noteworthy that while some provisions of the Porto Rico Government Act are drawn, seemingly, as though the Constitution were not effective in the island, every official mentioned in the act is required to take the constitutional oath. This requirement is essential, but its presence discredits the theory of the inefficiency of the Constitution in Porto Rico, because he who swears to support it is entitled to its protection.

The Constitution is the ultimate source of authority for every lawful act of the Federal Government. The power behind the act may be expressed; it may be plainly implied; it may be claimed by implication so refined as to provoke conflicts of opinion: but it must be derived from the organic law. This conclusion has been constantly affirmed by the Supreme Court. It is the very corner-stone of our law of constitutional interpretation. And, as the Government must rely on the enabling provisions of the Constitution for authority to act at all, it must rule its conduct according to the restraining provisions. Commenting on government in general, and our own in particular, Chief Justice Marshall said: "This original and supreme will [of the people] organizes the gov"ernment, and assigns to different departments their " respective powers. It may either stop here, or es" tablish certain limits not to be transcended by those "departments.

"The government of the United States is of the 
"latter description. The powers of the legislature "are defined and limited; and that those limits may " not be mistaken, or forgotten, the Constitution is "written." 1

The immeasurable difference between the limited powers of Congress and the omnipotence of Parliament is recognized by our courts, ${ }^{2}$ and it cannot be too strongly emphasized at this moment when a sudden admiration for English colonial policy has begotten a desire to imitate it.

"The powers of the British Parliament," says Mr. Justice Harlan, "furnish no test for the powers that "may be exercised by the Congress of the United "States. Referring to the difficulties confronting "the Convention of 1787 which framed the present "Constitution of the United States, and to the pro" found differences between the instrument framed by "it and what is called the British Constitution, Mr. "Bryce, an English writer of high authority, says in "his admirable work on the American Common"wealth: 'The British Parliament had always been, "“"was then, and remains now, a sovereign and con"“stituent assembly. It can make and unmake any " "and every law, change the form of government or " " the succession to the crown, interfere with the “" course of justice, extinguish the most sacred pri" "vate rights of the citizen. Between it and the “" " people at large there is no legal distinction, because "“ 'the whole plenitude of the people's rights and " "powers resides in it, just as if the whole nation "“were present within the chamber where it sits.

${ }^{1}$ Marbury $v$. Madison, I Cranch 137, I 76.

2 See Van Horne's Lessee 2 . Dorrance, 2 Dallas 304, 307. 
" "In point of legal theory it is the nation, being the " "historical successor of the Folkmoot of our Teu" " tonic forefathers. Both practically and legally, it is " " to-day the only and the sufficient depository of the " "authority of the nation; and is, therefore, within " " the sphere of law, irresponsible and omnipotent.' "No such powers have been given to or can be ex" ercised by any legislative body organized under the "American system. Absolute, arbitrary power ex" ists nowhere in this free land. The authority for " the exercise of power by the Congress of the United "States must be found in the Constitution. What" ever it does in excess of the powers granted to it, " or in violation of the injunctions of the supreme law " of the land, is a nullity, and may be so treated by " every person. . . . If the Parliament of Great "Britain, her Britannic Majesty assenting, should " establish slavery or involuntary servitude in Eng"land, the courts there would not question its author"ity to do so and would have no alternative except "to sustain legislation of that character. A very "short act of Parliament would suffice to destroy all "the guaranties of life, liberty and property now “ enjoyed by Englishmen. 'What,' Mr. Bryce says, " "are called in England constitutional statutes, such " "as Magna Charta, the Bill of Rights, the Act of " "Settlement, the Acts of Union with Scotland and “" Ireland, are merely ordinary laws, which could be " "repealed by Parliament at any moment in exactly " "the same way as it can repeal a highway act or “' 'lower the duty on tobacco. Parliament,' he fur"ther says, 'can abolish when it pleases any institu1 Vol. I, p. $3^{2}$. 
" ' ' tion of the country, the Crown, the House of Lords, " ' the Established Church, the House of Commons, "' 'Parliament itself.' ${ }^{\prime}$ In this country, the will of the "people as expressed in the fundamental law must "be the will of courts and legislatures. No court is "bound to enforce, nor is any one legally bound to "obey, an act of Congress inconsistent with the "Constitution." 2

If it seems astonishing that our government should not have the free hand of Great Britain in dealing with our new possessions, and this astonishment is much affected for the moment, we should remind ourselves that present difficulties merely accentuate an incapacity of our government not so radical from a British standpoint as are other incapacities to which we are well accustomed. For example, in the principal part of the republic, comprising the territory of the States, the Federal Government is incompetent to regulate the unit of society-the family; each State has its own laws of marriage, divorce, and legitimacy: It is incompetent to regulate the ownership and distribution of property, for these also are matters of State concern: It cannot designate the basis of popular government - the electorate; the voting strength of the republic is vested in forty-five electoral bodies, created by as many States, which are only forbidden to deny the suffrage to any person because of race, color, or previous condition of servitude: ${ }^{3}$ It cannot command revenues which are among the ordinary resources of

1 Vol. I, pp. 237, 238.

2 Robertson $v$. Baldwin, 165 U. S. $275,296$.

${ }^{3}$ See infra, p. 55 . 
European states, for it is practically debarred from collecting taxes on land and incomes ${ }^{1}$ nor can it, like the German Empire, enjoy the fruits of these direct taxes by way of contributions from the federated states.

In view of these and other incapacities incident to our peculiar government, especially its admirable incapacity for arbitrary rule, it is not surprising that the Constitution should be the law throughout the United States, and could it be maintained that our new possessions are not in the United States, we would have no right to govern them as we do, for the Supreme Court has declared: "By the Constitu"tion a government is ordained and established 'for “" ' the United States of America,' and not for countries "outside of their limits." 2

${ }^{1}$ See infra, p. 85 .

2 Ross's Case, I 40 U. S. $453,464$. 
THE APPLICATION OF THE CONSTITU. TION IN THE PHILIPPINES

The considered arguments against the Constitution for the Philippines affect the sanction of law, but they are really arguments of inconvenience. They rest upon the assumed inexpediency, if not the impossibility, of constitutional government rather than upon approved legal principles. The assumption cannot be disproved by reciting opinions of the Supreme Court, for it suggests a question of fact. It will appear, however, that our constitutional powers are adequate, and that our constitutional obligations, chiefly regarding citizenship and civil rights, slavery, commerce, and taxation, are not presumptively unendurable.

The Constitution permits the pacification of the Philippines by any method which public opinion should tolerate. Surely a government that suppressed the revolt of eleven States has constitutional power to deal with any insurrection in federal territory; and when reconstruction shall follow pacification, a government that "reconstructed" the South after the Civil War cannot decently complain of lack of power in the Philippines. Furthermore, the Con- 
stitution permits the President to administer the islands after a fashion until Congress shall exert its powers, ${ }^{1}$ and does not hamper Congress in providing a government suited to their needs. ${ }^{2}$

STATUS OF PERSONS

\section{Natural-Born Citizens}

All persons born in the Philippines after annexation, and subject to our jurisdiction are citizens of the United States; though, as we shall see, they are not members of the voting body of the republic.

This proposition is denied not only on the ground, already noted, that the Constitution is wholly ineffective beyond the States, but upon a peculiar interpretation of the first sentence of the Fourteenth Amendment, which reads: "All persons born or naturalized " in the United States, and subject to the jurisdiction " thereof, are citizens of the United States and of "the State wherein they reside." The last clause, "and of the State wherein they reside," is said to restrict the words "United States" to the several States. We are told that had the framers of the Amendment contemplated a broader field than the States they would have written, "and of the State "or Territory where they reside." This, certainly, they would not have done. Citizenship involves allegiance. Allegiance is due only to a sovereign. The territorial governments have no attribute of 
sovereignty, being merely the creatures of Congress and existing during its pleasure. Persons have indeed been described in judicial opinions as "citizens "of a Territory," but this must be understood as a term of convenient description. As "a citizen of "Philadelphia" describes a citizen of the State of Pennsylvania residing in one of its cities, so " a citi"zen of Alaska" means a citizen of the United States residing in one of those Territories whose position in the United States has been aptly indicated by likening them to "organized municipalities." 1 The clause is to be understood as a distinct command rather than as part of a general description. Its sole purpose is to compel each State to recognize as its citizens all persons residing therein whom the United States recognize as their citizens.

The narrow construction of the Amendment that would restrict United States citizenship to persons born or naturalized within a State is disapproved by the Supreme Court, which has said that a man "must "reside within the State to make him a citizen of it, "but it is only necessary that he should be born or "naturalized in the United States to be a citizen of "the Union": ${ }^{2}$ And Mr. Justice Bradley said in the same case: "The question is now settled by the "Fourteenth Amendment itself, that citizenship of "the United States is the primary citizenship in "this country; and that State citizenship is second" ary and derivative, depending upon citizenship of "the United States and the citizen's place of resi-

${ }^{1}$ See supra, p. 39.

2 Slaughter-house Cases, i6 Wallace 36, 74 . 
"dence." In a late opinion the Court says: "The words "“in the United States, and subject to the jurisdiction "'thereof,' in the first sentence of the Fourteenth "Amendment of the Constitution, must be presumed " to have been understood and intended by the Con"gress which proposed the amendment, and by the "legislatures which adopted it, in the same sense in " which the like words had been used by Chief Justice "Marshall in the well-known case of The Exchange; " and as the equivalent of the words 'within the limits " ' and under the jurisdiction of the United States,' and " the converse of the words 'out of the limits and juris" ' diction of the United States,' as habitually used in "the Naturalization Acts." 2 A scrutiny of Naturalization Acts, beginning with the Act of I795, will show that "the United States" wherein an applicant for citizenship must have resided for a prescribed period, and in which he may be naturalized, includes the Territories.

The terms " citizen," "citizen of the United States," and "citizens of the United States" are employed elsewhere in the Constitution to describe a larger body than the people of the States. The Constitution prescribes that a Congressman must have been seven years a "citizen of the United States," and a Senator nine years. Is the State of Utah unlawfully represented in the Senate on the theory that her Senators have only been citizens of the United States since Utah was admitted to statehood in 1896 ?

1 Page I I2. Chief Justice Marshall had anticipated this opinion many years before, saying: "A citizen of the United States residing in any State of the Union, is a citizen of that State." Gassies $v$. Ballon, 6 Peters $76 \mathrm{r}$.

2 U. S. v. Wong Kim Ark, I69 U. S. 649, 687. 
Only a natural-born citizen who has reached the age of thirty-five years and has resided fourteen years "within the United States" is eligible to the Presidency. Will it be contended that a man born in Colorado Territory in I864 was not born in the United States? Or that a man born in Ohio in the same year and taken in infancy to what is, since I889, the State of Washington, has not resided fourteen years in the United States? The Fifteenth Amendment reads: "The right of citizens of the "United States to vote shall not be denied or "abridged by the United States or by any State on "account of race, color, or previous condition of "servitude." This Amendment plainly contemplates a power in Congress to confer the suffrage. Now Congress can neither confer, deny, nor abridge the suffrage in any State, for each State has the exclusive power to designate its voting body, subject only to the limitation of this Amendment. ${ }^{1}$ The field

${ }^{1}$ See U. S. $v$. Cruikshank, 92 U. S. 542,555 . The broad powers of the States in the matter of the suffrage are well illustrated in the voting body designated by the Constitution of Minnesota, Art. VII, Sec. I: "Every male person of the age of twentyone years or upwards, belonging to either of the following classes, who shall have resided in the United States one year, and in this State for four months next preceding any election, shall be entitled to vote at such election, in the election district of which he shall at the time have been for ten days a resident, for all officers that now are, or hereafter may be elected by the people. First: Citizens of the United States. Second: Persons of foreign birth who shall have declared their intention to become citizens, conformably to the laws of the United States upon the subject of naturalization. Third: Persons of mixed white and Indian blood who have adopted the customs and habits of civilization. Fourth: Persons of Indian blood residing in this State, who have adopted the language, cus- 
of federal action in the matter of suffrage is then beyond the States, and the Amendment declares, in effect, that if Congress shall create a voting body in a Territory it cannot deny the suffrage to any citizen of the United States therein, that is to say, to any person owing allegiance to the United States, because of "race, color, or previous condition of "servitude."

We need not rely upon an inspection of constitutional texts alone to sustain our broad definition of a natural-born citizen of the United States. The Supreme Court declares that recourse must be had to the common law to determine who are native-born citizens, ${ }^{1}$ and the common law, ignorant of our State boundaries, makes all persons born within the dominion and jurisdiction of the sovereign natural-born subjects, or, in our republican phrase, "citizens." The Court says in the case cited: "Passing by ques"tions once earnestly controverted, but finally put at "rest by the Fourteenth Amendment of the Consti" tution, it is beyond doubt that, before the enactment " of the Civil Rights Act of I 866 or the adoption of "the Constitutional Amendment, all white persons, " at least, born within the sovereignty of the United "States, whether children of citizens or of foreigners, " excepting only children of ambassadors or public " ministers of a foreign government, were native-born "citizens of the United States." 2 This statement toms and habits of civilization, after an examination before any District Court of the State, in such manner as may be provided by law, and shall have been pronounced by said court capable of enjoying the rights of citizenship within the State."

${ }^{1}$ U. S. $v$. Wong Kim Ark, 169 U. S. 649.

2 U. S. $v$. Wong Kim Ark, I69 U. S. $649,674$. 
presents the opening words of the Fourteenth Amendment in their true light. They do not create citizenship of the United States, but affirm the preëxisting common-law rule of citizenship by birth, and secure to "all persons" the benefit of this rule, which as applied by the federal courts of this country in the past ignored the African race.

\section{Indians and Foreigners}

Persons who, though born in the United States, are not citizens, because not subject to the jurisdiction, are the children of foreign ministers, of Indians, and of alien enemies in occupation of our soil. ${ }^{1}$

Tribal Indians within the domain of the original States were set apart by the Constitution as a peculiar people, and with each extension of territory other tribes have been surrounded. Congress cannot make a man an "Indian" by calling him one, because, though the status of the Indian is in some respects indeterminate and in all respects anomalous, it is settled, at least, that he is a person born in the allegiance of a tribe of barbarous or savage origin, having its seat in United States territory, yet being, in the language of the Supreme Court, "a distinct po"litical community." 2 There are natives in the Philippines who appear to have maintained their political organization during the overlordship of Spain, as had the Seminoles in Florida, and who, like the Seminoles, will be segregated as Indians.

${ }^{1}$ See U. S. $v$. Wong Kim Ark, I69 U. S. 649, 693.

${ }^{2}$ Elk $v$. Wilkins, 112 U. S. 94, 99. 
The "Moros," as the Mohammedan natives are called, are in the "Indian" class. The Tagals and some other races are for the most part above it, though I confess that at one time I assumed, ignorantly, that the great majority of the islanders were barbarians. The Tagals are now miscalled a "tribe" merely to insinuate the propriety of treating them with the contempt usually displayed by civilized conquerors towards barbarians. In reality they emerged from the tribal state long ago, and at the time of our coming to the Philippines were the most conspicuous section of the great body of the Christian subjects of Spain in the islands.

"Alien enemies" is not a legal description of the Filipinos in arms. Without suggesting a general likeness between them and the Confederates of $186 \mathrm{I}$, in one respect their positions are not altogether dissimilar. Said the Supreme Court of the insurgent State of Texas and its people: "The State did not "cease to be a State, nor her citizens to be citizens of "the Union. If this were otherwise, the State must "have become foreign, and her citizens foreigners. "The war must have ceased to be a war for the sup"pression of rebellion, and must have become a war "for conquest and subjugation." ${ }^{1}$ In point of fact, the war in Luzon is waged for conquest and subjugation, yet it is not a foreign war. Like the Civil War it is an insurrection against the United States, and the status of the insurgents is determined, like that of the Confederates, by our assertion of sovereignty, and not by their assertion of independence.

${ }^{1}$ Texas $v$. White, 7 Wallace 700,726 . 
The Chinese and the other foreigners in the Philippines are within the protection of the rule that while an alien "lawfully remains here he is entitled to the "benefit of the guaranties of life, liberty, and prop" erty secured by the Constitution to all persons, of "whatever race, within the jurisdiction of the United "States. His personal rights when he is in this "country and such of his property as is here during "his absence, are as fully protected by the supreme "law of the land as if he were a native or naturalized "citizen of the United States." 1

\section{The Privilege of Election - The Plebiscite}

Treaties of annexation involving a part only of national territory frequently provide that the subjects or citizens of the ceding state may elect to retain their old allegiance, either unconditionally, or where the land is well peopled, and the acquiring state is unwilling to run the risk of having a large body of aliens domiciled in its territory, upon condition that they emigrate within a certain time. This election is often called a "right," and as such it may be conceded in an amicable transfer between states negotiating on an equal basis; but in case of a conquest it is nothing more than a privilege granted by the conqueror, who thereby waives his right to forbid the emigration of persons whom he might hold as subjects or citizens. ${ }^{2}$ In either case its real value often depends on the ability of the people to find homes elsewhere. 'This privilege was properly accorded,

${ }^{1}$ Lem Moon Sing $v$. U. S., $15^{8}$ U. S. $53^{8}, 547$.

${ }^{2}$ See U. S. $v$. Repentigny, 5 Wallace 2 I I, 260. 
without condition, to the Spanish-born residents in the Philippines. It was properly withheld from the Filipinos, as its allowance would have greatly embarrassed the United States without holding out any substantial advantage to the islanders.

The right or privilege of election is, I think, the nearest approach to a recognition in international practice of the ethical principle that government should exist with the consent of the governed, in its relation to the cession of territory. Some jurists, indeed, claim the sanction of international law for a right in the inhabitants of territory to determine its destiny by their vote, but in view of international practice their opinion must be regarded rather as an aspiration than a statement of the law. The United States have never required a plebiscite in any of their acquisitions, whether peaceable or forcible, and Secretary Seward is said to have protested, though in vain, against allowing the people of the Danish West Indies to vote upon the question of annexing the islands to the United States. ${ }^{1}$ Lord Salisbury bluntly defined English practice when he said in the House of Lords: "The plebiscite is not among the "traditions of this country." ${ }^{2}$ France, indeed, has annexed territory with the recorded approval of a majority of its people, though one is by no means convinced that she would have permitted the plebiscite without an assurance of its favorable result, or that she would have foregone her enterprise had the vote been unfavorable; and the story of plebiscites

${ }^{1}$ Bancroft, Life of Seward, II, 483 .

2 Hansard, 3d Series, Vol. CCCXLV, p. гз гт. 
generally does not impress one with their value. ${ }^{1}$ The truth is that the plebiscite, while it may be eminently just and practicable in some cases, does not rank among the working principles of international law. If a strong state is determined to despoil a weak one, it will not stop for a vote. If two states agree upon a transfer of territory, there is no legal, nor, necessarily, any moral reason why their purpose should be thwarted by the people who, at the moment, happen to be living in it.

\section{Change of Nationality}

The Filipinos, having been divested of Spanish allegiance, it remains to determine their relation to the United States. A natural consequence of the rule that annexed territory is impressed with the nationality of the acquiring state ${ }^{2}$ is the attribution of this nationality to its inhabitants. This result is accepted generally abroad, ${ }^{3}$ and has been approved in our federal courts. Said Chief Justice Marshall of the inhabitants of Florida after its cession to the United States: "The same act which transfers their "country, transfers the allegiance of those who "remain in it." ${ }_{4}$ And the Supreme Court said in a

${ }^{1}$ See Despagnet, Droit International Public, 2d Ed. 420 ; Phillimore, International Law, I, 585, 604 .

2 See supra, p. 20.

${ }^{3}$ For an interesting discussion as to the true date of the annexation of Algeria to France and the consequent attribution of French nationality to the native Algerians, see Hugues, La Nationalité Frangaise chez les Musulmans de l'Algérie, ro-r4.

${ }^{4}$ American Insurance Co. $v$. Canter, I Peters 5 II, 542. 
later case: "Manifestly the nationality of the inhabi"tants of territory acquired by conquest or cession "becomes that of the government under whose "dominion they pass, subject to the right of election "on their part to retain their former nationality by " removal or otherwise, as may be provided." ${ }^{1}$

The general rule must be applied to the Filipinos, unless it is effectively avoided by the clause in the Treaty of Paris reserving to Congress the right to determine their political status. Now while the term "political status" is by itself broad enough to include "allegiance" and "nationality," the clause is not to be construed as relieving the Filipinos from the one or denying them the other. Such a construction would certainly be impolitic. The treatment of these people as political nondescripts would not materially further a policy of invidious discrimination, because it would be impossible to deprive them of legal rights under the Constitution. Like the Mexicans of New Mexico, they have come under the jurisdiction of the United States as former subjects or citizens of the state which has ceded the land of their residence. They have a right to live in their native country, and they must possess in permanence at least the personal and property rights affirmed by the Supreme Court to foreigners during their sojourn. Furthermore, the residence in our territory of a multitude of persons without national duty or affiliation of any kind would be embarrassing in many ways.

Fortunately, the impolitic construction of this treaty clause is unlawful. While it is not impossible for an

${ }^{1}$ Boyd $v$. Thayer, I43 U. S. 135, I62. 
individual to lack nationality; ${ }^{1}$ while the people of Cuba are a community to whom a perfect nationality cannot now be attributed; nevertheless this anomalous condition is so opposed to public and private interests that it will never be recognized unless circumstances permit no other course. This is not the case here. By asserting sovereignty over the Filipinos, as the consequence of asserting it over the place of their residence, the United States inevitably claim their allegiance, and with the duty of allegiance is coupled the quality of nationality.

\section{Naturalized Citizens}

Are not the Filipinos citizens of the United States, duly naturalized by the operation of the Treaty of Paris? The Supreme Court has recognized a power to create citizens en masse by process of collective naturalization, "as by the force of a treaty by which "foreign territory is acquired." 2 The full meaning of this power has never been adjudicated, because the treaties of annexation considered by the Supreme Court have purported to confer citizenship expressly ; but Chief Justice Marshall significantly said of the citizenship of the people of Florida who remained there after the cession: "It is unnecessary to inquire "whether this is not their condition independent of "stipulation." 3 The Treaty of Paris contains no such stipulation. On the contrary, its reservation of the

${ }^{1}$ See Hall, International Law, 255.

2 Boyd $v$. Thayer, 143 U. S. $135,162$.

${ }^{3}$ American Ins. Co. $v$. Canter, I Peters 5 I I, 542. 
political status of the islanders for the pleasure of Congress was intended to exclude them from citizenship, if possible, ${ }^{1}$ but it does not repudiate their allegiance, and, in my opinion, we confer citizenship upon those from whom we claim allegiance. And if it be objected that allegiance denotes subjection but not necessarily citizenship, I reply that the United States do not divide their people into subjects and citizens. "In one sense the term sovereign," said Mr. Justice Wilson, "has for its correlative, subject. In " this sense the term can receive no application, for " it has no object in the Constitution of the United "States. Under that Constitution there are citizens, "but no subjects. "Citizen of the United States. " 'Citizens of another State.' 'Citizens of different “' 'States.' 'A State or citizen thereof.' The term "subject occurs, indeed, once in the instrument but " to mark the contrast strongly the epithet 'foreign' " is prefixed." 2

A classification of persons within the allegiance as citizens and as subjects is properly made in countries where citizenship carries political franchises. This is the rule in France, and so the natives of Algeria, though they are "Frenchmen," are called subjects unless they have complied with the terms of the law conferring citizenship. ${ }^{3}$ From the standpoint of our Constitution such a classification would be impossible, for we shall see presently that citizens of the United States have not, as such, any political franchise what-

1 See supra, p. 20.

2 Chisholm v. Georgia, 2 Dallas 419, 456.

${ }^{3}$ See Hugues, La Nationalité Française chez les Musulmans de l'Algérie, 9. 
ever. They are the men, women, and children whose relations to the republic involve the reciprocal duties of loyalty and protection, and, because all persons who are bound and benefited by these duties are equal before the Constitution, they are grouped under a single title.

"Citizens of the United States," is merely the equivalent of "British subjects," and "Frenchmen" in this regard, that each describes the national body of the respective states.

\section{Slavery}

The first section of the Thirteenth Amendment of the Constitution reads: "Neither slavery nor invol" untary servitude, except as a punishment for crime " whereof the party shall have been duly convicted, "shall exist within the United States, or any place "subject to their jurisdiction."

A whimsical argument against the supremacy of the Constitution in territory beyond the States is that this Amendment affirms a distinction between "the United States" and this territory, which is alleged to be designated by "any place subject to "their jurisdiction." This "place" has never been defined judicially. Certainly it includes American ships, and probably American legations abroad, and I think such localities beyond the geographical limits of the republic are the sufficient reason for the clause. ${ }^{1}$ It may be conceded, however, that know-

${ }^{1} \mathrm{Mr}$. Harrison says : "This Amendment was proposed by Congress on February ist, I86 - the day on which Sherman's army left Savannah on its northern march; and the words 'any place 
ledge of a debate on slavery, involving the relation of the Constitution to the Territories, ${ }^{1}$ may have impelled the framers of the Amendment to place the question beyond even discussion. But, whatever purpose ingenuity may decipher from the phrase, it would be a criminal perversion of the work of the Congress that adopted it, and of the States that ratified it, to thrust into their declaration abolishing negro slavery a denial of constitutional liberty to all Americans who happen to live beyond the States. This Amendment deals with the incident of slavery only. It has no bearing on the broad and distinct subject of the sphere of the Constitution. This is determinable by considerations antedating the Amendment, which, for this reason, can add nothing to the notion that the Constitution is meant for the States alone. For the same reason it can take nothing from the doctrine that the authority of the Constitution is conterminous with the territorial jurisdiction of Congress.

Slavery exists among the Mohammedans in the Philippines, and although these people may be treated as "Indians," and left with a large discretion in the management of their domestic affairs, they are within the purview of this Amendment, which, in fact, has been held to forbid a system of serfdom found among the Indians of Alaska. ${ }^{2}$

subject to their jurisdiction' were probably added because of the uncertainty as to the legal status of the States in rebellion, and not because of any doubt as to whether Nebraska, then a Territory, was a part of the United States."-North American Review, January, I 901, p. 6.

${ }^{1}$ See supra, p. 35 .

-Sah Quah's Case, 3I Federal Rep. 727. 
Concerning an agreement made with the Sultan of Sulu by the military authorities, the President says: " "Article $\mathrm{X}$ provides that any slave in the archi"pelago of Jolo shall have the right to purchase free"dom by paying to the master the usual market "value. The agreement by General Bates was made "subject to confirmation by the President, and to "future modifications by the consent of the parties " in interest. I have confirmed said agreement, sub" ject to the action of the Congress, and with the "reservation, which I have directed shall be commu"nicated to the Sultan of Jolo, that this agreement "is not to be deemed in any way to authorize or give "the consent of the United States to the existence "of slavery in the Sulu archipelago. I communicate "these facts to the Congress for its information and "action." As the article in question purports to accord a qualified recognition of slavery it is outlawed by the Constitution. We may not handle slavery with gloves. The gradual emancipation tolerated by England in Zanzibar is not permitted to us. There is not even a lawful process of emancipation. The Amendment declares sharply that slavery shall not "exist," and the Supreme Court has pronounced it to be "undoubtedly self-executing with"out any ancillary legislation, so far as its terms are "applicable to any existing state of circumstances. "By its own unaided force and effect it abolished "slavery, and established universal freedom." ${ }_{2}$

The full effect of the prohibition of "involuntary "servitude" has not been determined by the Supreme

\footnotetext{
${ }^{1}$ Annual message of 1899, p. 43.

2 Civil Rights Cases, ıо9 U. S. 3, 20.
} 
Court, which has decided, however, that it does not abrogate the ancient rule of the sea whereby a sailor shipping for a voyage may be compelled to perform his contract under pain of imprisonment, nor is intended to introduce "any novel doctrine with respect to "certain descriptions of service which have always "been treated as exceptional; such as military and "naval enlistments, or to disturb the right of parents " and guardians to the custody of their minor chil"dren or wards ... services which have from time "immemorial been treated as exceptional shall "not be regarded as within its purview." ${ }^{\text {Nor is }}$ it necessary to insist that a person can in no case be compelled to complete a particular undertaking an engineer who should be prevented from wilfully abandoning a pump forcing air into a mine would not be held in "involuntary servitude." But after making all exceptions warranted by inveterate usage or emergency, the Thirteenth Amendment appears to declare that an employer cannot of his own motion, or by the assistance of the state force an unwilling workman to perform his contract. As Judge Cooley says: "Contracts for personal services cannot, as a "general rule, be enforced, and application to be "discharged from service under them on habeas "corpus is evidence that the service is involuntary." ${ }^{2}$ And the Supreme Court has said: "If Mexican "peonage or the Chinese coolie labor system shall "develop slavery of the Mexican or Chinese race "within our territory, this amendment may safely be

1 Robertson $v$. Baldwin, $16_{5}$ U. S. $275,282$.

2 Constitutional Limitations, 6th Ed. $36_{3}$, note. 
"trusted to make it void." 1 What effect the enforcement of the Thirteenth Amendment against the coolie system would have upon agriculture in some of our new possessions cannot be known until the labor conditions are thoroughly understood. It is noteworthy, however, that Great Britain finds it expedient to legitimate this system in several of her colonies, shorn of most abuses, it is true, yet retaining the essential feature of compulsory service during an agreed period. And in the report on British New Guinea for I $897-98^{2}$ we read that Ordinance No. II of I897: "rendered it compulsory "on a native to perform the work for which he may "be duly engaged"; and Ordinance No. VIII of I 897: "provides that a deserting laborer may be re" turned to his employer." However, in view of the state of labor in Hawaii we are not free, at present, to criticize British policy. In June, I 899, the Supreme Court of Hawaii confirmed the order of a district magistrate who, under the Masters and Servants Act, had sentenced a man to imprisonment at hard labor "until he should consent to return to his "master and consent to serve according to law." 3 The prisoner was an Austrian who had been "im" ported" by the company under contract to work for three years. The Court did not attempt to distinguish the imprisonment from the "involuntary

${ }^{1}$ Slaughter-house Cases, 16 Wallace 36,72 ; cited in U.S. $v$. Wong Kim Ark, I69 U.S. 649,677 . For a description of peonage see Jaremillo $v$. Romero, I New Mexico 190.

2 Pages io, Ir.

${ }^{3}$ Honomu Sugar Co. v. Zeluch, 6o Albany Law Journal 2 r 3. 
"servitude" forbidden by the Thirteenth Amendment, but dismissed the Amendment with a curt reference to earlier opinions in which it had pronounced the Constitution of the United States to be of no force during "the transition period."

If it shall be finally determined that in the United States Territory of Hawaii a plantation hand may be imprisoned until he is ready to perform his contract to labor, perhaps a like system will some day be established in the States that have already practically disfranchised the negro.

\section{Political Franchises}

Citizens of the United States not residing in States have no voice in federal affairs, ${ }^{1}$ nor have they a constitutional right to regulate their own.

The entire sovereignty over territory beyond the States is vested exclusively in the federal legislature. This proposition was questioned in the Dred Scott case, ${ }^{2}$ and Senator Douglas and other statesmen declared that the people of the Territories possessed sufficient "popular sovereignty" to decide for themselves whether slavery should be allowed within their borders. The doctrine of "popular sovereignty" in the Territories was a political device for taking the question of slavery out of federal politics. It was wholly incompatible with the fundamental conception

${ }^{1}$ See supra, p. I4.

2 Scott $v$. Sandford, ig Howard 293, 501 . 
of the union of States, and is now thoroughly discredited. ${ }^{1}$ The definition of Filipinos as "citizens" carries no right to participate in governing the republic, nor any State, nor even the Philippines. They can become members of the voting body of the United States only by coming into a State and satisfying the requirements of the local law of suffrage. They can exercise in the islands only such political franchises as Congress may grant. In the language of the Supreme Court: "The personal and civil "rights of the inhabitants of the Territories are se"cured to them, as to other citizens, by the principles "of constitutional liberty which restrain all the agen"cies of government, State and national ; their politi"cal rights are franchises which they hold as privileges " in the legislative discretion of the Congress of the "United States." 2

\section{Civil Rights}

There is no absurdity in attributing the personal and civil rights of the Constitution to the Filipinos when the nature and limitations of these rights are understood. Surely the republic must regard life, liberty, and property everywhere as rights, not as privileges. Even these primary rights are not absolute. Each one may be forfeited for crime. Each is held subject to the legitimate claims of the State.

Of course the right to liberty confers the freedom

${ }^{1}$ See National Bank $v$. County of Yankton, ror U.S. I 29, I33; Murphy $v$. Ramsey, I14 U. S. 15, 44; Mormon Church $v$. U. S., I 36 U. S. I, 44.

${ }^{2}$ Murphy $v$. Ramsey, II 4 U. S. 15, 44. 
of the republic, and no law can check the orderly migration of Filipinos to any part of the country. A man's right to work in any part of the republic, and his right to send the lawful product of his labor to any part, rest upon precisely the same foundation of personal liberty. As for liberty of speech and of the press, expressly guaranteed by the Constitution, why should not a Filipino speak and write his mind when he may be punished for abusing his rights, and hung if, like the Chicago anarchists, his utterances are linked to the crimes they are intended to provoke?

The Filipinos are entitled to bear arms, but the Constitution affirms this right for "the security of a "free state," not for the benefit of insurgents; they may assemble and petition for redress of grievances, but the Constitution requires them to do so "peaceably."

Our rejection of the guaranties as constitutional standards of conduct in the Philippines would mean to the islanders the rule of a new master of higher purpose, of greater ability, of kindlier disposition than the old one, yet quite as free from the restraints of law. Defining the so-called rights of the islands under such a régime, the Secretary of War proffers "moral right," and " the nature of our Government," and "implied contract" as efficient substitutes for legal guaranties. ${ }^{1}$

In the same vein Judge Day, the head of the American Peace Commission at Paris, says: "What" ever the power of the American Government under "the Constitution, the American people, through

1 See Report for 1899, pp. 26, 27. 
"their executive and representatives in Congress, " may be trusted to see that there goes with Ameri"can sovereignty the underlying principle of free"dom and liberty for which our fathers fought and "for which they set up a government of and by and "for the people. A party which should ignore or "forget these principles would be relegated by the "people from power to obscurity."

A profession of good intentions is merely a pious opinion, not a substitute for a bill of rights. The Constitution originally adopted contained very few provisions of a bill of rights, and this omission was warmly defended by Hamilton, ${ }^{2}$ Wilson, ${ }^{3}$ and other statesmen. But the people mistrusted a government apparently capable of inflicting the abuses so intolerable under English rule. They made light of the objection that the prohibition of specific abuses might imply the power to inflict unforeseen ones. They demanded the guaranties that were quickly imposed in the first ten amendments, and these so thoroughly covered the ground that no further prohibition has been laid upon federal power save in the Fifteenth Amendment, forbidding the United States to deprive any person of suffrage because of "race, color, or pre"vious condition of servitude." The same jealousy of arbitrary power is manifested in all the constitutions of the States. How graceless, then, is the assertion that Filipinos and Porto Ricans find ample protection in the self-asserted righteousness of the governing

${ }^{1}$ Address before the Michigan Bar Association, May 23, 1900, p. I 2 .

2 The Federalist, No. 84 .

${ }^{3}$ Elliot's Debates, Ist Ed., III, 25 r. 
body of the republic, when this body has determined that neither prejudice of race or class or religion, nor the power of one or of many shall overcome the rights of its own members so far as the organic law enforced by the courts can maintain them! And who will say that constitutional restraints so necessary in the self-governing sections of the republic are superfluous in the Philippines? Who will say that abuse of power decreases with the growth of opportunity?

The Bill of Rights is not an essay on liberty. It is a law forbidding acts which, for the most part, are political crimes, and the illegality of these acts does not depend on the place of their commission or the color of their victims, if they are committed within the territorial jurisdiction of Congress.

Conscious of the injustice of arrogating the exclusive benefits of the federal bill of rights to the people of our country who need them least, the opponents of constitutional rule in the new territory are casting about for a device whereby some of these benefits at least may be carried to the islands without drawing the Constitution after them.

In Goetze $v$. U. S., ${ }^{1}$ the Court, commenting on a proposition that "a republic cannot be allowed to "govern without any restraint," says: "In this very "principle we may find the safeguard of such terri"tory. If the United States tried to govern any " territory in violation of the spirit pervading repub"lican institutions, such action might be held illegal "by courts on the basis of this principle. It may ${ }^{1}$ ro3 Federal Rep. 72, 84 . 
"be admitted that the constitutional guaranties of "civil rights would apply to territory under the sov"ereignty, but not a part, of the United States. "Certain civil rights which we believe belong to " every one, are crystallized into the negative pro"visions of our Constitution, in order to prevent any " wrongful and improper use of our power, and these "may well be held to control our power wherever " it reaches. These considerations may be found to "limit us in governing any territory. Whether they " do or not it is not necessary here to decide. If "they do, it will be because we cannot violate the "principles of government embedded in our institu"tions, not because Porto Rico is a part of the "American nation. It will be for the reason thus "stated by Mr. Justice Bradley in Mormon Church " $v$. United States: 'Doubtless Congress in legis" "lating for the Territories would be subject to those " "fundamental limitations in favor of personal rights " "which are formulated in the Constitution and " " its amendments; but these limitations would exist " "rather by inference and the general spirit of the " 'Constitution, from which Congress derives all its " "powers, than by any express and direct applica"“tion of its provisions." Mr. Justice Bradley's much-quoted dictum is not a fit conclusion to these observations, because it recognizes the obligation of the guaranties, which is the important thing, and describes it as being inferential rather than direct, which is not important. Concerning the observations themselves I have only to say that a judge who asserts that our new possessions are not "part of the "American nation" is estopped from anticipating that 
their inhabitants may be entitled to the guaranties; for the Supreme Court has declared: "The Constitu" tion can have no operation in another country." 1 And " the spirit pervading republican institutions" cannot be invoked by the courts to discredit acts of government, except as it is embodied in the Constitution, for in this written law the people of the United States have gone as far as they intended to go in restraining their government. The right of the Supreme Court to condemn acts conflicting with these limitations has long been conceded; but should the court enthrone a "spirit" whose responses must reflect the opinion or prejudice of the questioning judge, it would assert an intolerable power of intervention in affairs of state, as well in New York as in the Philippines.

\section{TAXATION - COMMERCE}

The authority of the Constitution in the Philippines has an important bearing upon the subject of federal taxation, especially the taxation of commerce.

\section{Foreign Commerce}

First, of commerce between the islands and foreign countries. After our occupation of California had been confirmed by the ratification of the treaty of cession, the Administration abandoned the military tariff imposed during the belligerent occupation, and proceeded to collect upon foreign imports the duties

${ }^{1}$ Ross's Case, r4o U. S. $453,464$. 
of the general Tariff Act. ${ }^{1} \quad$ A different practice prevails in the Philippines, where the Administration imposes duties at discretion. Now even if Congress were authorized to levy peculiar taxes upon foreign goods brought into annexed territory, the President would have no right to do so. His ability to collect duties at all rests upon a presumed intention of Congress evidenced by a tariff act, and it is not definitely settled that even such collections are valid unless they are ratified by Congress. ${ }^{2}$ To admit his right to levy taxes at discretion because of a latent power in Congress to do this would imply the existence of an executive power to originate revenue legislation in United States territory, in derogation of the provision of the Constitution: "All bills for raising "revenue shall originate in the House of Represen"tatives."

The next question is whether Congress itself may impose special duties upon foreign goods brought into the Philippines. As a matter of fact, Congress has never exacted peculiar duties in new districts, but has always extended the existing tariff laws either about the time of annexation or shortly thereafter. As a matter of law, the Administration insists that the constitutional provision that "all duties, im"posts, and excises shall be uniform throughout the "United States" does not apply to the new possessions. The Secretary of War says in his report for I 899:" "The provision of the Constitution prescribing

${ }^{1}$ Cross $v$. Harrison, 16 Howard 164 .

${ }^{2}$ See infra, p. Ir 3 .

${ }^{3}$ Page 27. 
" uniformity of duties throughout the United States " was not meant for them [the Porto Ricans], but was " a provision of expediency solely adapted to the con"ditions existing in the United States upon the con"tinent of North America." I should call a law assuring equal taxation and freedom of trade throughout the republic a provision of justice, not of expediency, and I fail to understand upon what principle a court could hold this provision to be operative in Maine, Louisiana, Alaska, and Ohio, and in Mexico and Labrador, should we annex them, yet inoperative in Porto Rico. From this makeshift survey of the field of the Constitution we turn with confidence to Chief Justice Marshall's delimitation suggested by this very provision, and embodied in his famous definition of the "United States " - "our great repub"lic, which is composed of States and Territories. "The District of Columbia, or the Territory west of " the Missouri, is not less within the United States, "than Maryland or Pennsylvania; and it is not less " necessary, on the principles of our Constitution, " that uniformity in the imposition of imposts, duties, " and excises should be observed in the one than in "the other." ${ }^{1}$ Here is the law of the commercial unity of the republic expounded by its foremost interpreter, and the Philippines, being within the republic, are within the law.

\section{Domestic Commerce}

We have next to consider the question of duties upon commerce between the islands and our main-

${ }^{1}$ Loughborough $v$. Blake, 5 Wheaton $3{ }^{17}$, 319. 
land. A statement of the Court in Fleming $v$. Page ${ }^{1}$ is often cited in this relation: ". . . under our rev"enue laws every port is regarded as a foreign one, "unless the custom-house from which the vessel "clears is within a collection district established by "act of Congress, and the officers granting the "clearance exercise their functions under the author"ity and control of the laws of the United States." This statement misleads in so far as it lends color to the assertion that precedent sanctions the taxation of this commerce. It is conceded that a port is foreign in a fiscal sense, though the United States claim title to it, if they have not gained possession, as in the case of Baton Rouge in the Louisiana territory ceded by Spain to France and by France to us, but actually held by Spain for some time after we had taken possession of New Orleans; or have lost possession, as in the case of Castine in Maine, seized by the British forces in $1814:^{2}$ and a port is foreign, too, though the United States have possession, if they await the ratification of a treaty to perfect their title, as in the case of San Juan in Porto Rico, or if they hold it by mere force of arms, as in the case of Tampico in the Mexican War, which was the matter before the Court in Fleming v. Page. But a scrutiny of administrative practice down to the end of the Mexican War shows that, with perhaps trifling and peculiar exceptions, as in the case of New Orleans, ${ }^{3}$ duties were not collected upon goods carried between old and new possessions after our

${ }^{1} 9$ Howard 603, 61 7 .

2 U. S. $v$. Rice, 4 Wheaton 246.

${ }^{3}$ See Cross $v$. Harrison, 16 Howard $164,199$. 
right to the latter had been confirmed by the ratification of a treaty of cession. The notable illustration of the rule of free intercourse, however, is the case of California after the Mexican War. Upon the ratification of the treaty ceding California to the United States, the Administration promptly recognized the trade between the new territory and the rest of the country as domestic, as appears by the following passage from a letter of the Secretary of State, quoted by the Supreme Court in Cross $v$. Harrison: " "This government de facto [the tempo"rary government of California] will, of course, "exercise no power inconsistent with the provisions " of the Constitution of the United States, which is "the supreme law of the land. For this reason no "import duties can be levied in California on " articles the growth, produce, or manufacture of the "United States, as no such duties can be imposed " in any other part of our Union on the productions "of California. Nor can new duties be charged in "California upon such foreign productions as have "already paid duties in any of our ports of "entry, for the obvious reason that California is "within the territory of the United States." And the Court also refers to a despatch from the Secretary of the Treasury "providing for the reciprocal "admission of goods which were the growth, etc., of "California and the United States, free of duty, into "the ports of each." The California precedent was followed upon the annexation of Alaska, the Secretary of the Treasury deciding that furs and oils brought in from the new territory were not subject ${ }_{1}^{1} 16$ Howard 164,185 . 
to duty. ${ }^{1}$ The present Administration disregards these precedents. It treats the commerce between the Philippines and our mainland as foreign, and collects duties in each upon the imported products of the other, exacting in the former place a tax determined by itself, and in the latter the duties of the Tariff Act. It is ungenerous and unlawful to treat our new citizens as foreigners in their commercial relations, and to hamper an intercourse whose promotion should be our first concern. So disastrous did this practice prove to Porto Rico that the President said to Congress: "Our plain duty is to abolish all "customs tariffs between the United States and "Porto Rico, and give her products free access to "our markets." ${ }^{2}$ But this distress was caused by his refusal to follow the constitutional practice of his predecessors. The President is not authorized to hamper internal commerce by laws of his own making, and this he has done in levying duties on merchandise carried from our mainland to our islands. Nor is he authorized to enforce a tariff act against merchandise brought here from islands which, since its enactment, have become a part of the United States. The Tariff Act of 1897 is entitled "An Act to provide revenue for the Government "and to encourage the industries of the United "States"; and by the enacting clause its operation is limited to "articles imported from foreign countries." As the islands have been made domestic territory by the Treaty of Paris they are not within the purview

${ }^{1}$ Synopsis Treasury Decisions, $\mathbf{1 8 6 8 , p p . ~ 1 0 , ~ 2 0 . ~ L e t t e r ~ o f ~ S e c - ~}$ retary $\mathrm{M}$ 'Culloch to the Collector at New York, April 6, I 868.

2 Annual message of 1899, p. $5^{\circ}$. 
of an act intended to impose burdens upon foreign products exclusively. And this construction of the act is required by the Constitution, for the rule of uniformity which, as we have seen, forbids Congress to impose different duties upon foreign imports in different sections of the United States, forbids it to impose any duties whatever on commerce between them. "In war, we are one people," said Chief Justice Marshall, "in making peace, we are one people;" and these axioms, whose application to all persons within the jurisdiction of Congress none will question, are recited merely to emphasize the equal breadth of another: "In all commercial relations, we "are one and the same people." 1

Our inquiry into the subject of federal customs duties leads to these conclusions: Under no circumstances can these duties be lawfully collected in the annexed islands or the mainland upon the imported products of either; duties collected upon foreign goods brought to the islands must be the same as are imposed in the rest of the United States. ${ }^{2}$

\section{The Porto Rico Act}

While the advocates of the taxation of our commerce with the new possessions have not abandoned their position that federal duties, imposts, and excises need be uniform throughout the States only, they have added another string to their bow by incorporat-

${ }^{1}$ Cohens $v$. Virginia, 6 Wheaton 264,413 .

2 Mr. Edward B. Whitney, of the New York Bar, has contributed an instructive article on the Porto Rico Tariffs to the Yale Law Journal of May, $\mathbf{1 9 0 0 .}$ 
ing in the Porto Rico Government Act a system of so-called local taxation, in the hope that it may be tested by principles less rigid than those controlling federal taxation. The system makes Porto Rico a fiscal unit wholly independent of the great fiscal district of the United States.

On behalf of this system it is urged that the island should be self-supporting, though, temporarily, the Act appropriates certain federal revenues to its use. Now it is desirable that all Territories should pay their own expenses, as far as practicable, and this is customary, but the Federal Government pays the salaries of the governor, the judges, and the secretary, and some small legislative expenses. In reply to the objection that Porto Rico is charged with the payment of salaries borne elsewhere by the federal treasury, it may be said that as the act contemplates her exemption from federal charges (though I note in passing that she is charged with the maintenance of a United States District Court), she should get nothing from a treasury to which she contributes nothing. But this is a perverse view of the relation between the Federal Government and the Territories. This Government is bound to protect and administer all its Territories. Here is an independent, unconditional, and continuing duty springing from the assumption of sovereignty. Reciprocally, a Territory ought to bear its proper share of federal expenses. Instead of saying that it need not contribute to a federal treasury from which it gets nothing, we must understand that it ought to contribute because, appropriations apart, it receives necessarily the protection of the republic. The plea that the Porto Ricans 
should be excused from this duty because of their misfortunes is without merit, so long as we do not regard poverty as conferring immunity from taxation on our mainland. Federal burdens press as heavily upon millions of people here as they would upon the Porto Ricans.

A just policy requires that the fiscal status of Porto Rico be assimilated to that of our other Territories, and I am satisfied that the act of Congress cutting off the island in this, as in other respects from communion with the republic does not represent the real attitude of our people, nor of the Administration itself toward the inhabitants of this island who so heartily welcomed us a few months ago. Had Porto Rico been our only spoil of war no protest would have been made against her incorporation into the United States. But the Philippines were acquired. Possibly, opportunity may suggest the seizure of lands even more remote and uncongenial; and so Porto Rico is being used as an experiment station for testing novel schemes which, if legitimated, may be applied seriously elsewhere.

More important than the policy of the Porto Rico fiscal system is the question whether it is constitutional in all its parts, and the features to which I call special attention are, $\mathrm{I}$. The intention (not perfectly realized) to exempt Porto Rico from federal taxes. 2. The collection in Porto Rico upon imports from foreign countries of the duties prescribed in the federal tariff act; upon merchandise brought from our mainland and not already placed on the free list by the military government of fifteen per 
cent. of these duties, and in addition an internal revenue tax equal to that imposed in Porto Rico on like articles of local manufacture; upon all imported coffee a duty of five cents per pound. 3. The collection at the ports of our mainland upon all imports from Porto Rico of fifteen per cent. of the federal tariff rates, and in addition an internal revenue tax on articles withdrawn for consumption equal to the federal tax imposed upon similar articles of local manufacture. The net revenue thus collected in the island, and the gross revenue thus collected in the mainland are segregated from the general fund of the federal treasury, and are designated as a special fund at the President's disposal to be expended for the government and benefit of Porto Rico.

The first question is whether Congress may exempt any territory within its jurisdiction from the operation of existing federal tax laws. The Constitution prescribes that direct taxes, which include taxes on land ${ }^{1}$ and incomes, "shall be apportioned "among the several States which may be included "within this Union according to their respective "numbers," that is to say, according to their population. But when Congress levies a direct tax in the States it is not obliged to extend it to outlying territory, though it may do so in any division in which a census has been taken. ${ }^{3}$

Direct federal taxes are only of theoretical interest. Practically, they are excluded from the federal bud-

${ }^{1}$ See Hylton $v$. U. S., 3 Dallas $\mathbf{1} 7$ I.

${ }^{2}$ Pollock $v$. Farmers' Loan \& Trust Co., 157 U. S. 429 ; 158 U. S. 6or.

${ }^{3}$ Loughborough $v$. Blake, 4 Wheaton 317 . 
get because the rule of apportionment precludes their being levied with substantial justice.

Regarding indirect taxes, which are the main sources of federal revenue, we are bound by the constitutional mandate that all "duties, imposts, or ex"cises shall be uniform throughout the United States," and, as I have shown that this means uniform throughout the territory within the jurisdiction of Congress, the only question of present interest is whether exemption of a section of this territory from an indirect tax would render unlawful its collection elsewhere. Certainly not where territory acquired after the passage of a tax law is exempt from its operation simply because no provision for collection has been made. Doubtless, there is a moral obligation to collect current duties, imposts, and excises in annexed territory as soon as possible, but it would be absurd to hold that a refusal by a President to collect according to the California precedent, or a delay on the part of Congress, perhaps unavoidable, or even a deliberate abstention as in the present case, would invalidate tax laws which, when enacted, operated uniformly throughout the United States. No one has had the temerity to suggest that an importer in New York may recover duties paid, because like duties are not collected in Manila, or that an estate in New York may escape the inheritance tax, because it is not collected in Porto Rico.

Should Congress levy a new federal duty, impost, or excise, and exempt property in our new possessions from its incidence, the question would be presented squarely whether the rule of uniformity is 
satisfied by a law prescribing a tax uniform wherever imposed, or whether it exacts imposition everywhere in order to warrant collection anywhere. Lately, the Supreme Court was urged to declare the federal inheritance tax invalid on the ground that Congress had not provided for its collection in the District of Columbia, but the Court, "without attempting to de"termine whether the necessary construction of the "statute would require the inclusion of the District " of Columbia within its terms, aside from any special "provision bearing on the question," found that a section of the act covered the District by necessary implication. ${ }^{1}$ Note that the Court did not contemplate the possibility of a deliberate exemption, but suggested the very different question whether an indirect tax law must be construed so as to embrace all territory, and only refused to discuss it because a specific provision of the act sufficiently designated the District of Columbia. I am satisfied that should the Court deal with a tax law purporting to exempt territory it must either ignore the incidental purpose of Congress by declaring the exemption to be ineffective, or defeat the main purpose by annulling the law because of its lack of uniformity; "be"cause," says Chief Justice Marshall, " it is admitted "that the Constitution not only allows, but enjoins, " the government to extend the ordinary revenue sys"tem to this District" ${ }^{2}$ - that is, the District of Columbia; and this injunction applies as well to all United States territory.

${ }^{1}$ Knowlton $v$. Moore, ${ }_{7} 8$ U. S. $4 \mathrm{I}$, 106.

Loughborough $v$. Blake, 5 Wheaton 317,325 . 
Having found that the failure to provide for the collection of certain current federal taxes does not vitiate the Porto Rico system itself, or react destructively upon federal tax laws, we will examine its pretensions as a law framed for the purpose of raising local revenue.

The United States having the power to acquire and govern territory, Congress must be competent to provide means for administering it, and to this end it may impose local taxes, either directly or through local authorities acting under its supervision. The result is that political districts beyond the States are, like the States, subject to a double system of taxation, federal and local, the difference being that in the latter case the separate taxes are imposed by two governments, Federal and State, while in the former they are imposed by the Federal Government acting in two capacities.

In imposing these local taxes, whether directly, as in Alaska, or through the agency of a local government, as in New Mexico, Congress is free from certain constitutional restraints which affect it in levying federal taxes. ${ }^{1}$ Direct taxes are, as we have seen, practically excluded from the federal budget, but they appear in the budgets of outlying districts, where the rule of apportionment does not apply: Lands in the city of Washington and in New Mexico are taxed for local purposes on independent lines. Excises imposed for the common defense and general welfare of the United States must be uniform, but they may vary widely when levied for local purposes: A wholesale liquor dealer pays a license tax

${ }^{1}$ See Gibbons $v$. District of Columbia, I 16 U. S. 404 . 
of $\$ 100$ in New Mexico, ${ }^{1}$ and $\$ 250$ in the city of Washington. ${ }^{2}$ But a tax proposed for territorial purposes may suggest constitutional restrictions which cannot be dismissed by calling the tax a local one, especially when it is to be levied upon commerce beginning or ending beyond the boundaries of the Territory; and some of the duties of the Porto Rico Act fall within this category.

The duties of the general tariff law which are levied on foreign imports into Porto Rico, and applied to local uses, are not objectionable: For here the act really extends the general law to the island, and, at the same time, appropriates specifically the revenue collected therein.

The duties collected in Porto Rico on imports from our mainland are local in purpose, and they are levied by Congress acting as a local legislature; but because their imposition does, in fact, create within the United States a peculiar customs district in respect of internal commerce, it contravenes a purpose of the uniformity clause of the Constitution.

The duties collected on our mainland on imports from Porto Rico are not local taxes. They are not imposed or collected in the island: Nor could Congress authorize a local government to impose or collect them here. Their appropriation to the use of Porto Rico does not make them local taxes. The imposition and the appropriation of taxes are distinct acts, however closely they may be joined in a single statute, and the quality of a federal tax is as plainly impressed upon these duties as though they

${ }^{1}$ Compiled Laws, I 897, Sec. 4122.

$2_{2}$ Supp. R. S., p. I 5 . 
were collected under a general tariff law and their proceeds granted afterward to Porto Rico by an appropriation act. Being federal duties they are invalid because not "uniform throughout the United States." Being invalid, the Porto Rico tax scheme fails to legitimate the dearest purpose of its promoters the declaration of a federal power to prevent outlying possessions from competing in what is called our "home market."

The duty of five cents per pound collected in Porto Rico upon all importations of coffee is a local tax, evidently imposed for protection rather than revenue. This tariff tax of local benefit and application is, I believe, the first in our history; certainly none has been scrutinized by our courts. The Constitution expressly provides for tariffs of federal benefit only; for while a State may be specially permitted to lay duties on imports, it must pay the net proceeds into the federal treasury. ${ }^{1}$ The imposition of this special tax differentiates the ports of the island from those of our mainland, and I have a strong impression that all customs taxes, wherever, or for whatever purpose levied, must be judged by the federal rule of uniformity, because they affect, necessarily, the commerce of the republic which, excepting trade carried on within the several States and Territories, is made by the Constitution a matter of exclusive federal concern.

There is bitter opposition to applying to the Philippines the constitutional rule of uniform tariff taxes. It is asserted that Congress cannot impose uniform duties on foreign imports that will be equally

${ }^{1}$ See Constitution, Art. I, Sec. ro. 
fair to the islands and to the mainland; but this suggests merely a phase of the persistent tariff controversy. Doubtless the new phase presents new difficulties, yet recalling that one tariff act drove South Carolina to the edge of rebellion, and that another led Louisiana to the Treasury for sugar bounties, we need not apprehend more extreme results from extending our revenue system to the Philippines.

Free trade between the Philippines and Porto Rico and the mainland may affect important agricultural interests here. Should Cuba be annexed, notwithstanding our promise, the disturbance will be more serious. If manufactures shall be established in the islands the wave of disturbance may cover a wider area. But these incidents of arnexation cannot influence the interpretation of the Constitution.

\section{The Commercial Unity of the United States}

In anticipation of the possible range of this great question of commerce with annexed territory let us inquire whether protection of the so-called "home "market," being unattainable through invidious tariffs, may be secured by direct prohibition, by embargo: A method harsher in sound, yet not more potent than taxation; needlessly brutal, perhaps, in present circumstances, yet likely to find apologists should we annex land crowded with workmen eager to sell their cheap wares in our great market. The answer depends on the extent of the federal power to "regulate commerce" conferred by the Constitution upon Congress in respect of commerce "with foreign 
"nations, and among the several States, and with "the Indian tribes." Domestic territory beyond the States is not mentioned, but as there is commerce between this country and the States, and as Congress, the supreme: legislature, must have some power over it, we find no difficulty in defining this to be neither more nor less than a power "to regulate."

As I draw a distinction between the scope of the federal power as it is applied to international and Indian, or to interstate commerce, it is material to determine whether commerce between the Territories and the States is to be distinguished from, or likened to one of the: specified suljects. Certatinly this commeres should not be set apart, for whatever classification is warranted ly the Constitution is based on a difference between trade in some sense foreign, and domestic trate. Now this commerce is essentially domestic, being the intercourse between the States and the territory which is their "common "property" and a part of the United States. lior this reason, it must be classed with commerec between the States, so I shall substitute for "interstate com"merce" the term "lomestic commerce."

Many years ago Julge Story inquired: "Can C'on"gress, under the power to regulate commerce among "the States, prohilit the: transportation or export of "goods or products from one State: to another? "lix. gratia, can Congress prohibit the exportation "of slaves from onc State to another for sale?" "2

1 Sece Stoughtenburgh r. Ilemuick, 129 11. S. 141.

Commentaries, 20 lid., Sec. 107.5, note 3 . In comsidering this question I utilize parts of an article en liceleral I'rust lechislation,

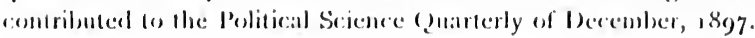


The specitic question is now of histeric interest only, and I think it will be asteed thas principles of law which might hase been urged as.anst maintain ing a constitutional right of fiec trate in human beings are not applicable to a commerce trem which the slave has disappeared-it. interd, he over actually tigured in federal jurisprudence as an artick of commerese.

In considering I udge story's sencral question it is not necessary to determine whether congress may forbid domestic trattic in articles decmed to be essentially prejudicial to public health or morals, though it may be noted that. perhaps, in this resard congeress has more power ever commeres between the Terri. tories and the States, than over that between the States, since in the lerriteries it possesses, ungues tionably, that prower of police which in the States ap pears to be rested solely in the loc.3l geveruments. Nor is it material to this discussion to consiter spe cially the power of interdietion asserted by Congress in the so-called luti.loust lat of 1 soo, autherizins the seizute of trust-make aticles in course of inter state transit. ()ur precise yuestion is whether (on gress is competent to divite the United States inte sections by drawing a line through any part, and for bidting commeres between them, cither semerally or in specitic articles. In 1 sog Congress larit an com burge upen forcign trate, and deseribed the measure "as ncither hostile in its chatacter not as justitying or

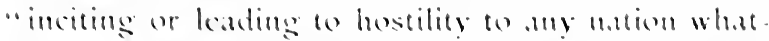
"crer." The constimtionslity of the Bmburse dit

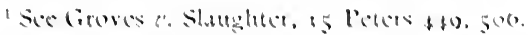

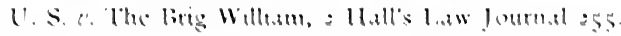


was attacked, but was sustained in a District Court; and some years later Justice Marshall referred to " the universally acknowledged power of the Govern"ment to impose embargos," described them as "sometimes resorted to, without a view to war, and "with a single view to commerce," and said of the act of 1807: "By its friends and its enemies it was "treated as a commercial, not as a war, measure." 1 And Judge Story said: "If it could be classed at all as "flowing from or incident to any of the enumerated " powers, it was that of regulating commerce." 2 Now the power conferred in respect of foreign, Indian, and interstate or domestic commerce is in each case "to regulate," and from this identity in the terms of the grants it has been assumed that the three powers are coextensive. But it will not be difficult to show that the power over domestic commerce is not identical with the power over commerce with foreign nations, ${ }^{3}$ and with the Indians. The assertion of identity between the powers over domestic and Indian commerce may be dismissed almost summarily. The Indian tribes are, in the language of Chief Justice Marshall, " in a state of pupilage. Their relation to " the United States resembles that of a ward to its "guardian. They look to our Government for pro"tection; rely upon its kindness and power; appeal "to it for relief to their wants; and address the "President as their great father." ${ }_{4}$ Whatever re-

${ }^{1}$ Gibbons $v$. Ogden, 9 Wheaton $\mathbf{1}$, I92. See also Legal Tender Cases, 12 Wallace $457,55^{\circ}$.

2 Commentaries, Sec. I 289. See also The Federalist, No. Ir.

${ }^{3}$ See Madison's Works, IV, 15 ; Groves $v$. Slaughter, 15 Peters 449, $5 \circ 5$.

${ }^{4}$ Cherokee Nation $v$. Georgia, 5 Peters I, 17. 
lation the people of the United States may bear to the Federal Government, it is not this. The dependent position of the Indians justified the Supreme Court in saying: "As long as these Indians remain a dis"tinct people, with an existing tribal organization, "recognized by the political department of the gov"ernment, Congress has the power to say with whom "and on what terms they shall deal, and what articles "shall be contraband." 1 Whatever power Congress may have over domestic commerce, it is not this. It is a fair rule of interpretation that, when powers in respect of several subjects are assumed to be coextensive merely because of identity in the terms of the grants, the differentiation of one subject discredits the assumption as to the rest. But we need not stop here; for, in point of fact, the assumed parallel between domestic and foreign commerce is quite as illusory as in the case of Indian trade, and for the same reason - a radical difference in the status of the parties.

The United States deal with a foreign nation as one sovereign with another. They have no connection, and, apart from the obligation of treaties, no conventional relation with the foreign state. Their attitude toward other nations is dictated by policy, tempered in some directions by treaty and international law; and they may discriminate between them - inclining toward one and away from another - as their interests require.

If Congress may interdict foreign commerce, it is by way of carrying out the policy of a sovereign the United States - in opposition to, or disregard of
${ }^{1}$ U. S. $v \cdot 43$ Gallons of Whisky, 93 U. S. 188, 195. 
the policies of other sovereigns to whom it owes no legal duty in the premises.

Obviously a right to interdict, which may inhere in the power to regulate commerce with foreign or dependent nations cannot be attributed by analogy to the power to regulate our own. Because we may forbid intercourse with a foreign nation, essentially an unfriendly act despite any protestation to the contrary, and forbid private dealings with Indians in order to protect childish wards from the rapacity of traders, it does not follow that we may turn the weapon of embargo against our own countrymen, or treat them as children of a "great father."

Federal power over domestic commerce is distinguished from the neighbor subjects of foreign and Indian trade, and from that war power which justified non-intercourse legislation during our Civil War, ${ }^{1}$ because it relates to traffic among the, presumably, loyal people of a common country. It must be considered on its own merits. "The Constitution," says the Supreme Court, "does not provide that inter"state commerce shall be free, but, by the grant of "this exclusive power to regulate it, it was left free, "except as Congress might impose restraints." 2 This means that domestic commerce is not free in the sense of being private enterprise wholly beyond federal supervision. Federal power to regulate commerce is not limited to annulling State laws, and enjoining private acts that would hinder it. This, the passive side of the power, is maintained in the courts. The active side is expressed in legislation,

${ }^{1}$ See The Reform, 3 Wallace 617 .

2 U.S. $v$. E. C. Knight Co., ${ }_{5} 6$ U.S. I, I I. 
and, while its range has not been definitely established, the nature of the subject must preclude its being extended to the point of interdiction. "It has "been said," says Chief Justice Marshall, "that the "Constitution does not confer the right of inter"course between State and State. That right " derives its source from those laws whose authority " is acknowledged by civilized man throughout the " world. This is true. The Constitution found it " an existing right, and gave to Congress the power "to regulate it." 1 The last sentence would mean something very different were it altered to read: "The Constitution found it an existing right, and "gave to Congress the power to interdict it"; and this confused proposition would so pervert the law as to defeat its true and most admirable purpose.

The right of intercourse mentioned by Marshall obtained among communities practically independent, for the Articles of Confederation were but " a rope of sand," and it was because intercourse was seriously hampered by States exercising their sovereign powers of restriction that this clause was inserted in the Constitution. In fact, the need of commercial unity was the greatest incentive to the establishment of "the more perfect Union" assured by the Constitution. The States did not transfer to Congress the sovereign power of restriction which each possessed. They renounced these powers, left them in the air, and authorized Congress to maintain the freedom of trade established by their renunciation. To regulate domestic commerce, then, is to facilitate an intercourse placed beyond

${ }^{1}$ Gibbons $v$. Ogden, 9 Wheaton $1,211$. 
reach of prohibition, and, while regulations may in fact involve some restraint upon the conduct of particular intercourse, they have their warrant and purpose in the facilitation of all intercourse.

\section{VALUE OF THE CONSTITUTION IN NEW TERRITORY}

In affirming the authority of the Constitution in the Philippines, I am far from anticipating the transformation of an Asiatic dependency of Spain into a well-ordered section of the United States by any magical power of written law. Constitutional rule will not prevail throughout the islands until the authority of the United States shall be as supreme in fact as it is in theory.

The gap between fact and theory, so marked in the Philippines, is not a novel circumstance in our history. The influence of the Constitution spread slowly throughout the vast domains we have annexed from time to time; isolated communities made their own laws; sparsely peopled regions had none. A Southern Confederacy once defied the Constitution, and, temporarily, suspended its active authority throughout a wide area; yet the Supreme Court said of an insurrectionary State: "She never escaped "her obligations to that Constitution, though for a "while she may have evaded their enforcement." 1

These untoward conditions illustrate the general proposition that constitutional guaranties are not thoroughly efficient unless persons injured by their violation have recourse to competent tribunals for

${ }^{1}$ Keith $v$. Clark, 97 U. S. 454,46 r. 
redress. How far such courts as may now sit in the islands are competent I do not discuss, for it may be admitted that until Congress shall authorize suitable tribunals constitutional rights will receive imperfect protection. But this admission must be made in regard to the whole republic. The only court named in the Constitution is the Supreme Court, whose original jurisdiction is strictly confined to "all cases affecting ambassadors, other public minis"ters and consuls, and those in which a State shall "be a party." ${ }^{1}$ What inferior courts there shall be, what their jurisdiction, when and how their judgments involving the questions mentioned in the Constitution as reviewable by the Supreme Court shall be carried to this tribunal, are determinable by Congress, which cannot be forced to create a court, or directed in defining its jurisdiction, or prevented from abolishing it. Generally speaking, the people of the United States depend upon the facilities afforded by the Judiciary Acts for the orderly enforcement of their rights, and in saying this we suggest the high office of courts wherever justice is truly respected.

Before leaving the subject of the jurisdiction of courts it will be profitable to note a marked difference between the American and English systems. The Judicial Committee of the Privy Council affirmed an ancient rule when they said in Bishop Colenso's case: "It is the settled prerogative of the "British Crown to receive appeals in all colonial "causes." ${ }^{2}$ The royal prerogative, however, has

${ }^{1}$ See Marbury $v$. Madison, I Cranch 137.

2 The Lord Bishop of Natal, 3 Moore P. C. C., N. S. I 5. 
long been exercised in accordance with the judgment of the Judicial Committee, a court selected from the Council according to rules established by Parliament. This court of appeal has a broad and varied jurisdiction. For example, it will entertain an appeal from the act of a colonial governor in imprisoning an African chief, ${ }^{1}$ from the order of a colonial court denying certain powers and privileges to a colonial legislature, ${ }^{2}$ from the judgment of a police magistrate in a petty colony; ${ }^{3}$ and it will receive appeals in criminal cases generally whenever it appears that "by a disregard of the forms of legal "process, or by some violation of natural justice or "otherwise, substantial and grave injustice has been "done." ${ }^{4}$ Under the British system, then, the subjects of the Queen in all parts of her dominions may, in certain cases, appeal for redress of injuries to a tribunal whose territorial jurisdiction expands with the expansion of the empire. Furthermore, the courts at Westminster have a common law right to grant the writ of habeas corpus: "which writ," said Chief Justice Cockburn, " in the absence of any pro"hibitive enactment, goes to all parts of the Queen's "dominions." 5

Our Supreme Court has, as we have seen, an original jurisdiction so restricted as to exclude all citizens of the republic from invoking its protection as a constitutional right. Especially noticeable, in

${ }^{1}$ Sprigg $v$. Sigcau [1897], A. C. 238.

${ }^{2}$ Speaker, etc., $v$. Glass, L. R. 3 P. C. C., 560.

${ }^{3}$ Falkland Islands Co. $v$. The Queen, I Moore P. C. C., N. S. 299.

4 Dillet's Case, 12 App. Cas. 459.

5 Anderson's Case, 3 Ellis v. Ellis 487, 494. 
contrast with English practice, is its inability to grant the writ of habeas corpus in virtue of organic power ; ${ }^{1}$ except, of course, in cases affecting ambassadors, other public ministers, and consuls. ${ }^{2}$ The appellate jurisdiction of the Supreme Court, including the matter of habeas corpus, is conferred by Congress, and it can hear appeals from such courts only as Congress shall designate. The designation of these courts in annexed territory is, therefore, a condition precedent to the opening of the Supreme Court to the inhabitants, to their enjoyment of the means of redress accorded to the rest of the community.

After the authority of the United States shall have been established in the Philippines, federal courts opened, and necessary laws enacted, after the government shall have done its part toward confirming the rule of the Constitution, the islanders must learn to live up to it before it can mean to them what it means to us. We do not hand down the Constitution to the Filipinos in the anticipation of an early acceptance of its principles. Indeed, the unanimous opinion that the islands should never be admitted to statehood affirms our conviction that the islanders ought never be trusted with a share of the political power of the republic. We do not believe the enthusiastic prophecy with which the First Philippine Commission closes its preliminary report: "When peace and prosperity shall have been estab-

${ }^{1}$ Bollman's Case, 4 Cranch 75, 94 ; Yerger's Case, 8 Wallace 85,87 .

${ }^{2}$ See Siebold's Case, ı०० U. S. 37 1, 374. 
"lished throughout the archipelago, when education "shall have become general, then, in the language " of a leading Filipino, his people will, under our "guidance, 'become more American than the Ameri" "cans themselves." "

A hostile environment does not annul, though it may impair, the efficiency of the Constitution. In the Philippine Archipelago, as in all United States territory, the Constitution confers rights upon the ignorant and the unwilling as well as upon those who value them; enjoins our public servants to respect it always; justifies resistance to forbidden acts; and, in theory of law, renders void every command and illegal every act disregarding its prohibitions. For by the law of this Constitution all land under the sovereignty of Congress is one country; all people within its jurisdiction are one people, who enjoy life, liberty, and property of constitutional right without regard to which side of a boundary line between State and Territory or of lines of latitude or longitude they happen to live; and these lines cannot be made a hindrance to the course of legitimate commerce.

A few months ago this statement was generally accepted, and it would not be attacked to-day had the Treaty of Paris limited our acquisitions to American territory. It is the circumstance of conquest in Asia, with its suppressed but inevitable suggestion of further aggrandizement in the East, that provokes 
the assertion that at last we have gone beyond the proper sphere of the Constitution.

Assuming, for the sake of argument, that this assertion is true, or at all events that it expresses the deliberate wish of the American people, how shall we deal with the question it presents? Certainly not by accepting an injurious rule as a perpetual obligation, or by refusing to admit that the Constitution must come at last to reflect a matured public opinion. If the application of the Constitution in the Philippines will cause serious embarrassment, the approbation of law will not make it endurable. Or, if the American people are unwilling to treat the islands as United States territory in any circumstances, no rule of law will long compel them. I am convinced that either event should move us to relinquish sovereignty over the country we cannot, or will not govern according to our Constitution. The taking over of millions of Asiatics who are deemed unfit for fellowship must increase our burdens without bringing new strength to bear them; and we may yet need the strength that inheres only in a people united by the bonds of sympathy, and of equality before the law.

Withholding the Constitution from the Philippines must tend to lessen respect for it here. It is impossible that we, who have maintained the necessity of constitutional restraints for the ordering of our intelligent and self-governing community, should disregard them anywhere without weakening our faith in their virtue.

Should the Constitution be denied to the Philippines upon any pretext a drawback from indiscriminate expansion will be removed. While acquisition 
of territory means the enlargement of the United States and the reception of new citizens, while Congress must govern all country within its jurisdiction as a social and commercial unit, the American people will not covet outlying land if its acquisition means fellowship with uncongenial multitudes. It is objected that any restraint upon appropriating territory as spoil of war will embarrass our military arm. Must we survey land before invading it, lest we stumble upon an unwelcome addition to the United States? Shall we sacrifice the right to indemnify ourselves for the cost of successful war? Surely these questions are not serious. A wise policy of expansion is promoted by a determination to gain desirable territory, not by a weakness for seizing anything within reach. The theory that conquest entails perpetual responsibilities is, too often, merely the conqueror's excuse for keeping coveted land. As for indemnity, it is gained directly by exactions of money, or, indirectly, by retaining desirable land. It is a contradiction in terms to say that it may be gained by keeping undesirable land.

Recognition of the Constitution in the Philippines will not check the expansion of our republic: It will tend to guide the course of expansion aright.

Should the above considerations be overborne by a determination to hold the Philippines as a subject province at all cost, let the Constitution as it stands remain unspoiled by interpretations restricting it to the States, or conditioning its efficacy in national territory upon the pleasure of Congress, or the treatymaking body. Let us frankly admit that in ruling 
without the restraint of organic law the government would assume an office requiring the approval of imperial standards for its acceptance, the delegation of imperial powers for its administration, and then approve these standards and delegate these powers in a special amendment of the Constitution. I have seen no considered suggestion that the Constitution be amended, yet it must come to this if the United States are to govern subject provinces with lawful and adequate powers. A short amendment would serve to distinguish the republic, governed under the old organic law, from outlying provinces ruled as policy shall dictate.

Meanwhile, the present Constitution is the law. And to the objection that the treatment of our new possessions is one of those purely political matters in which the judiciary must follow its coördinate departments, and not presume to check them, I reply that the immensity of the issues does not affect the judiciary in determining whether in fact there is a law of the land applicable to a case at bar. Shall this suitor pay a tax? Shall that one be deprived of liberty? These may be momentous political questions, without the precincts of the Court; within, they are judicial questions. 


\section{CHAPTER IV}

\section{THE GOVERNING OF THE PHILIPPINES}

The inclusion of the Philippines within the boundaries of the United States, and the aegis of the Constitution, are results of acquiring territorial sovereignty, and while this sovereignty is maintained we must address ourselves to practical questions of government and policy involved in the administration of United States territory. Some of these have been already considered; of the rest I shall consider only the primary questions concerning the powers of our President and Congress, and our attitude toward some of the principal institutions of the old order.

THE POWERS OF THE PRESIDENT

\section{Executive Powers}

The President is in possession of the Philippines, and his governing of them, provisionally, by military agents is a lawful exercise of executive power. This government originated in a belligerent occupation of foreign territory, and, agreeably to the precedent approved by the Supreme Court in the case of California, it was not dissolved by the trans- 
fer of the islands at the end of the war, but continues until superseded by Congress. ${ }^{1}$

The rightful existence of this government being conceded, we must determine its powers. The President's annual message of 1899 stated that the government of Porto Rico was maintained by the Executive Department "under the law of belligerent "right," ${ }^{2}$ and of course this statement included the Philippines, since both districts were in like case. The "law of belligerent right" appears to be, in this case, the will of the commander-in-chief of the forces imposed upon any matter whatever.

Now by what right can the President act under this "law" in any territory vested in the United States by the Treaty of Paris? Belligerent right is predicated upon a state of war. Porto Rico was then, and has remained at peace, and, in Milligan's case, ${ }^{3}$ Chief Justice Chase declared the invariable rule: "Where "peace exists the laws of peace must prevail." Belligerent right is predicated upon a state of formal war, the termination of which has been declared by the Supreme Court to be a fact determinable by the political department, whose decision will be respected by the judiciary. ${ }^{4}$ Without discussing whether the formal war inaugurated by Congress in the spring of 1898 was terminated, in point of law, before the exchange of ratifications of the treaty of peace on April II, I899, it certainly cannot be prolonged

${ }^{1}$ Cross $v$. Harrison, 16 Howard $164,193$.

2 Page 50.

${ }^{3} 4$ Wallace 2, 140.

${ }^{4}$ The Protector, I 2 Wallace 700 . See also U.S. $v$. Yorba, I Wallace 4 I 2, 423. 
beyond this date. This exchange, at least, was the final act of peace. As our courts have no knowledge of a state of war since, they have no reason for recognizing the law of belligerent right in the islands. There is an insurrection in the Philippines, but there is not a formal war. We have carefully refrained from treating the insurgents as belligerents. In fine, the law of belligerent right is as inapplicable in our new possessions as it was in the like case of California, of which President Polk said: "Upon the exchange of ratifications of the treaty of "peace with Mexico . . . the temporary govern"ments which had been established over New Mex"ico and California by our military and naval com"manders, by virtue of the rights of war, ceased to "derive any obligatory force from that source of "authority. . . ." 1 The President's governments in Porto Rico and the Philippines are precisely alike in origin and powers. Though military, as distinguished from civil governments established by Congress, they are not to be administered according to the laws of war. As in quiet Porto Rico, before the passage of the Government Act, so now in the disturbed Philippines the President is the steward of United States territory, and the fact that this territory is under the jurisdiction of Congress, though not yet organized under its laws, goes far toward indicating the real duties, powers, and limitations of his stewardship.

The President is pledged to uphold the sovereignty of the United States throughout their dominions; and

${ }^{1}$ Messages of the Presidents, IV, $6{ }_{3} 8$. 
they magnify his office who urge him to recognize a Filipino republic, or declare a protectorate, or acknowledge in any way the existence of a local sovereign. The islands are in his charge, not at his disposition.

Of the strictly military powers of the President it must be understood that in the face of insurrection he enjoys precisely the same authority in the Philippines as elsewhere in the territory of the United States, including the right to call on the States for militia to serve in the islands if, in his judgment, it be necessary. ${ }^{1}$

Although the authority of the President is called "military," it has a civil side. We shall see, presently, that the annexation of a country does not abolish all its old laws and governmental agencies, and that perhaps some laws of Congress may extend to it by their own force. The President is competent to enforce these laws and utilize these agencies as far as circumstances permit. Thus far the President's powers are normal, being wholly of an executive nature.

\section{Usurpation of Legislative Power}

There remains the question whether the President may lawfully exercise legislative powers in the ceded territory pending action by Congress, and I mean by legislative powers the enactment of new laws and the

${ }^{1}$ See Constitution,Art. I, §8; Military Laws of the U. S., §§ 1256 , 1505; Martin $v$. Mott, 12 Wheaton 19. 
repeal, alteration, or suspension of old ones, the extension of acts of Congress, the creation of offices, the imposition of new taxes and the appropriation of their revenue - in fine, the powers of Congress. Sir William Anson says of English practice: "Colonies " acquired by conquest or cession fall at once under " the legislative powers of the Crown in Council, sub" ject always to these limitations, that Parliament "might intervene and make provision for the govern"ment of the colony, and that the Crown could not " make laws 'contrary to the fundamental principles' "of English law, nor presumably enforce such laws "if found among the colonists at the time of ces"sion." 1 The power to legislate for annexed territory thus vested in the Crown in Council is not enjoyed by the President when the United States acquire territory; it vests in Congress, whose jurisdiction attaches at once, ${ }^{2}$ and within this jurisdiction there is no room for an executive prerogative of legislation, even by the permission of Congress. "That Congress can"not delegate legislative power to the President," says the Supreme Court, "is a principle univer" sally recognized as vital to the integrity and main"tenance of the system of government ordained by "the Constitution." ${ }^{3}$

The prohibition against executive legislation in United States territory is not affected by the judgment of the Supreme Court upon the Kearny Code of New Mexico. This code was promulgated by

1 The Law and Custom of the Constitution, The Crown, $2 \mathrm{~d}$ Ed. 274.

2 See infra, p. $12 \mathbf{1}$.

${ }^{3}$ Field $v$. Clark, 143 U. S. $649,692$. 
General Stephen M. Kearny in 1846 , while in command of our forces in hostile occupation of New Mexico. It was argued that the code lapsed upon the termination of the belligerent status of the territory by its formal cession to the United States, leaving the old Mexican law as the law of the land. But the Court decided that the Kearny Code was entitled to respect as the law in force at the date of cession. ${ }^{1}$ Here the Court recognized a code of purely executive, indeed of belligerent, origin ; yet its decision is not an authority for the exercise of general legislative powers in annexed territory, for this is a part of the United States, while the Kearny Code was proclaimed in a foreign land. In other words, the powers of legislation which, according to Leitensdorfer $v$. Webb, may be exercised by the President as commander-in-chief of our forces in belligerent occupation of foreign territory, where Congress has no jurisdiction, are not enjoyed in the United States, where Congress is supreme. Nor is the prohibition affected by the decision in Cross $v$. Harrison: After the ratification of the treaty ceding California to the United States had been communicated to our military governor in occupation of the territory, he ordered that the duties of the Tariff Act should be collected upon foreign imports, created the office of collector, and appointed a civilian thereto, with a salary. In dismissing a suit for the recovery of duties paid under protest, the Court said: "It has "been sufficiently shown that the plaintiffs had no "right to land their foreign goods in California at "the times when their ships arrived with them, ex-

${ }^{1}$ Leitensdorfer $v$. Webb, 20 Howard 176 . 
"cept by a compliance with the regulations which "the civil government were authorized to enforce"first under a war tariff, and afterward under the " existing Tariff Act of the United States. By the "last, foreign goods, as they are enumerated, are "made dutiable; they are not so because they are "brought into a collection district, but because they "are imported into the United States. The Tariff "Act of I 846 prescribes what that duty shall be. "Can any reason be given for the exemption of for" eign goods from duty because they have not been " entered and collected at a port of delivery? . . . "The right claimed to land foreign goods within the "United States at any place out of a collection "district, if allowed, would be a violation of the "provision in the Constitution which enjoins that all "duties, imposts, and excises shall be uniform " throughout the United States. Indeed, it must be "very clear that no such right exists, and that there "was nothing in the condition of California to ex" empt importers of foreign goods into it from the "payment of the same duties which were chargeable " in the other ports of the United States." 1 The gist of this paragraph is that a tariff act is so far effective in territory annexed after its passage that the President, in possession, is expected to collect the duties; but the Court did not appear to be thoroughly satisfied with this position, for at the close of the opinion we read: "We do not hesitate to say, if "the reasons given for our conclusions in this case "were not sound, that other considerations would

${ }^{1}$ Cross v. Harrison, 16 Howard 164,198 . (The italics are mine.) 
"bring us to the same results"; and the last of these considerations, which are generally of a practical nature, is "that the Congress has by two acts " adopted and ratified all the acts of the government " established in California upon the conquest of that "territory, relative to the collection of imposts and "tonnage from the commencement of the late war "with Mexico to the I2th November, I849, ex" pressly including in such adoption the moneys raised " and expended during that period for the support of "the actual government of California after the ratifi"cation of the treaty of peace with Mexico. This "adoption sanctions what the defendant did. It "does more - it affirms that he had legal authority "for his acts." From the opinion in Cross v. Harrison we gain the impression that these acts of the President in California were made good by Congress, rather than warranted by his own powers.

In applying the rule that the President is without legislative power in United States territory to the present case, I do not suggest an invariable test by which administrative decrees issued from Washington directly, or through the military government in the islands, are to be approved as executive regulations or condemned as acts of legislation. It is sufficient to know that decrees plainly of the forbidden sort are promulgated in the Philippines.

The remarkable instance is the legislative activity of the Commission now installed in the Philippines. The First Philippine Commission was appointed before the ratifications of the Treaty of Paris had formally completed our legal title to the islands. It 
was instructed to investigate, to conciliate, to report recommendations, but not to govern. ${ }^{1}$ The very different office of the present Commission is indicated by the following passage from the President's instructions of April 7, I900: "Beginning with the "first day of September, I900, the authority to " exercise, subject to my approval, through the Sec"retary of War, that part of the power of govern"ment in the Philippine Islands which is of a "legislative nature is to be transferred from the "Military Governor of the islands to this Com" mission, to be thereafter exercised by them in the " place and stead of the Military Governor, under "such rules and regulations as you shall prescribe, " until the establishment of the civil central govern" ment for the islands contemplated in the last fore"going paragraph, or until Congress shall otherwise "provide. Exercise of this legislative authority will "include the making of rules and orders, having the " effect of law, for the raising of revenue by taxes, " customs duties, and imposts; the appropriation and "expenditure of public funds of the islands; the " establishment of an educational system throughout "the islands; the establishment of a system to se"cure an efficient civil service; the organization and " establishment of courts; the organization and es"tablishment of municipal and departmental gov" ernments; and all other matters of a civil nature "for which the Military Governor is now competent "to provide by rules or orders of a legislative "character." 2

${ }^{1}$ See Report of the Philippine Commission, I, $18{ }_{5}$.

2 President's message of December 3, I 900. 
Here is a positive assertion of an executive power to govern the Philippines without the interposition of Congress. Considering that the power claimed includes the supreme right to levy taxes in United States territory, it is not perceived why, were the claim a lawful one, the President could not ascertain and dispose of all the public lands in the islands, intrust the material development of the country largely to private monopolies, and then turn over to Congress the vast estate committed to his stewardship with the best part of its assets gone, and some of its greatest potentialities mortgaged. The Administration, indeed, disclaims the right to do such improvident things, ${ }^{1}$ but while this disclaimer is evidence of a just policy, it is inconsistent, theoretically, with the great powers claimed.

Research may disclose some instances of executive usurpation of the powers of Congress, but I think the present Administration is the first that has ever made new laws for United States territory under claim of right; certainly it is the first to defend its course before the courts.

As the Administration declares that its government of the islands "is maintained by the law of bel"ligerent right," it may imagine that it enjoys the arbitrary powers of a conqueror. Or, as it seems to be committed to the doctrine that the Constitution is inoperative in the ceded territory, it may assume all governmental powers upon the theory that the constitutional separation of powers does not affect the President as the custodian of the Philippines. Neither of these positions is tenable, as I have shown.

${ }^{1}$ See Opinions of the Attorney-General, vol. xxii, $544,546,55 \mathrm{I}$. 
Arbitrary executive acts are not, indeed, always inexcusable or irreparable. "I am quite aware," says an eminent jurist, "that in times of great public danger " unexpected perils, which the legislative power " have failed to provide against, may imperatively "demand instant and vigorous executive action, pass" ing beyond the limits of the laws; and that when " the Executive has assumed the high responsibility " of such a necessary exercise of mere power, he " may justly look for indemnity to that department " of the government which alone has the rightful " authority to grant it - an indemnity which should "be always sought and accorded upon the clearest "admission of legal wrong, finding its excuse in the " exceptional case which made that wrong absolutely " necessary for the public safety." 1

The redeemable legislative acts of a President are those which Congress could have passed, and can ratify. President Taylor sought and gained legislative approval for some acts of the military government of California, ${ }^{2}$ and, already, Congress seems to have adopted, as far as possible, the legislation of the military government of Porto Rico. ${ }^{3}$

Legislatures have also passed acts of indemnity, protecting from suit persons concerned in the execution of illegal executive decrees. ${ }^{4}$ Thus Parliament acted in the case of "the forty days' tyranny" in I 766, during which the British Government sus-

${ }^{1}$ Executive Power, by Benjamin R. Curtis; reprinted in G. T. Curtis's Constitutional History of the U. S., II, 673 .

${ }^{2}$ See Messages of the Presidents, V, 19 ; and supra, p. I13.

${ }^{3}$ See Porto Rico Government Act, § 7 .

${ }^{4}$ See Phillips $v$. Eyre, L. R. 4 Q. B. 225 ; L. R. 6 Q. B. I. 
pended the laws permitting the export of corn. Thus Congress acted for the protection of all persons who executed the orders of the military authorities engaged in conducting the Civil War. ${ }^{1}$

Whenever the Administration has legislated for Porto Rico and the Philippines since their annexation it has invaded the province of Congress, and all arguments of extenuation must come at last to the plea of necessity.

In considering this plea we must dismiss at the outset the notion that the assembling of Congress in stated session worked a change in the President's powers as administrator of the annexed territory by depriving him of legislative functions enjoyed of necessity during the recess. These powers are the same in recess as in session, since, in theory of law, the President never lacks the coöperation of the legislature, except, perhaps, during the brief time needed to convene it in special session. If, then, the President possessed legislative powers of necessity when he might have called Congress but did not, his right must be based upon the mere inaction of Congress, and not upon the physical impossibility of its acting, for this was due to his failure to convene it; and on this theory he would possess legislative power while Congress sits but does not act. And this appears to be the opinion of the Administration, for during the last session of Congress the Secretary of War issued a decree forbidding the foreclosure of mortgages in Porto Rico for six months, unless Congress should otherwise provide. But it is impossible that legislative powers should accrue to the President because of the

${ }^{1}$ See Beard $v$. Burts, 95 U.S. $434,43^{8}$. 
inaction of Congress. If, in his judgment, legislation for annexed territory is necessary, he may commend it to Congress in regular or special session ; and if Congress shall not legislate on his motion or on its own, it is presumed to be satisfied with the existing body of law comprising the Constitution, the old law of the territory, and such United States statutes as may extend of their own force.

Whatever moral weight a plea of necessity may have when, in a recess of Congress instant action is required to avert a threatened peril, it has none in this case. The governing of the islands is not an emergency in any extenuating sense. Congress had provided for their acquisition before it adjourned in March, I 899, and must be presumed to have expected that the President would be called upon to take charge of them during the usual recess. If, before the next regular session, there had arisen a need for legislation, the President should have convened Congress. He cannot plead the emergency of a condition caused by his failure to call the legislature.

Then in December, I 899, Congress assembled in stated session, during which it neglected the Philippines. Another recess followed, and, during this session and recess, the President persisted in legislating, no longer encouraged by even the pretense of emergency. The fact is that the President and Congress have combined to exalt the one and degrade the other by approving the theory that the President is a better legislature for the islands than Congress. As a matter of mere policy this theory is not commended by assuming that the alternative to executive legislation by the President's agents acting 
on the spot, with some knowledge of local conditions, was the direct regulation of insular affairs by Congress sitting thousands of miles away in absolute ignorance of these conditions. The practicable alternative was the establishment by Congress of a provisional government competent to exercise its delegated authority. In point of constitutional law the theory is not even open to discussion.

When the people commenced the Constitution with the law, "All legislative powers herein granted "shall be vested in a Congress of the United "States," they laid a prohibition upon all Presidents at all times - upon Washington, prefigured as our first chief magistrate, as upon his unknown successors.

The incapacity of the executive department to legislate for unorganized territory was recognized by President Jefferson in the case of Louisiana ${ }^{1}$ and by President Polk in the case of California $;^{2}$ and the wretched plight of Alaska, a Territory neglected by Congress for more than thirty years, and accorded a proper government only a few months ago, has been laid before Congress by successive Presidents, none of whom supposed that the inactivity of the legislature gave him the right to act in its stead. Yet, while President McKinley said in his annual message of 1899, " "There is practically no organized form "of government in the Territory [Alaska]; there is "no authority except in Congress to pass any law,

${ }^{1}$ Messages of the Presidents, I, ${ }_{3} 63$.

2 Messages of the Presidents, IV, $5^{8} 9,638$.

${ }^{3}$ Page 48. 
" no matter how local or trivial, ..." he does not hesitate to legislate freely for the unorganized Philippine territory, and that this legislative power is not really assumed upon the plausible, though mistaken, ground of the existence of insurrection ${ }^{1}$ is shown by the fact that it was exercised in the peaceful territory of Porto Rico during the military régime.

The legislative decrees in the Philippines are not justified by any intrinsic merit, though decrees possessing this quality may be ratified by Congress in the public interest. Nor are they excused by reason of necessity, for Congress could have authorized the enactment of laws of like tenor through unimpeachable agencies. Indeed the worst feature of the case is that we are not asked to be generous toward an Administration that pleads even plausible necessity as an excuse for overstepping the law: We are expected to applaud an Administration that, like the British Crown, asserts a right to make laws for new territory until the legislature shall see fit to interpose. Here is an assumption of power which merits the denunciation that Judge Curtis, at one time a member of the Supreme Court, and always a loyal citizen, launched against the Administration during the Civil War:

"It has been attempted by some partisan journals " to raise the cry of 'disloyalty' against any one who " should question these executive acts.

"But the people of the United States know that

${ }^{1}$ The executive duty of suppressing insurrection in United States territory, whether in the Philippines or in New Mexico, does not carry an executive prerogative of making laws for the disturbed district. 
"loyalty is not subserviency to a man or to a party "or to the opinions of newspapers, but that it is an "honest and wise devotion to the safety and welfare "of our country, and to the great principles which " our constitution of government embodies, by which " alone that safety and welfare can be secured. And "when those principles are put in jeopardy, every "truly loyal man must interpose, according to his "ability, or be an unfaithful citizen.

"This is not a government of men. It is a gov"ernment of laws. And the laws are required by "the people to be in conformity with their will de"clared by the Constitution. Our loyalty is due to "that will. Our obedience is due to those laws; and "he who would induce submission to other laws, "springing from sources of power not originating in "the people, but in casual events, and in the mere "will of the occupants of places of power, does not "exhort us to loyalty, but to a desertion of our "trust." 1

\section{THE POWERS OF CONGRESS}

Congress is supreme in the Philippines. It acquired jurisdiction the moment the islands became United States territory. There is no room for the notion that jurisdiction does not attach until Congress actually legislates. Congress is supreme throughout the United States; it may legislate deliberately, reluctantly; it may shirk its duty; but it cannot

${ }^{1}$ Executive Power; reprinted in G. T. Curtis's Constitutional History of the United States, II, 67 I. 
escape the responsibility that goes with jurisdiction. In legislating for the Philippines, Congress will merely exercise jurisdictional rights already vested in it - vested by the ratification of the Treaty of Paris, in my opinion, but, at any rate, by the appropriation of the $\$ 20,000,000$ called for by the Treaty. ${ }^{1}$

\section{Source and Extent of Congressional Powers}

There is some difference of opinion as to the precise source of the power of Congress to govern the territory lying beyond the States. "The power "of governing and legislating for territory," says Chief Justice Marshall, "is the inevitable conse"quence of the right to hold territory. Could this "proposition be contested, the Constitution of the "United States declares that 'Congress shall have " " power to dispose of and make all needful rules " " and regulations respecting the territory or other “" "property belonging to the United States." "2 And he said in a later opinion: "In the meantime "Florida continues to be a Territory of the United "States, governed by virtue of that clause in the "Constitution which empowers Congress 'to make " "all needful rules and regulations respecting the " "territory or other property belonging to the " " United States." "

"Perhaps the power of governing a Territory " belonging to the United States which has not, by "becoming a State, acquired the means of self-

${ }^{1}$ See supra, p. 22.

${ }^{2}$ Sère $v$. Pitot, 6 Cranch 332, 336. 
"government, may result necessarily from the fact "that it is not within the jurisdiction of any particu"lar State, and is within the power and jurisdiction " of the United States. The right to govern may be "the inevitable consequence of the right to acquire "territory." I In Chief Justice Taney's opinion, the power to "make all needful rules," etc., refers solely to land ceded by the States, and the general power to govern territory "stands firmly" on the right to acquire it. ${ }^{2}$ This opinion has the better reason: It is self-justifying; and its adoption leaves the constitutional clause relating to territory to express simply the power to manage property, especially to sell the public lands, which, when the whole clause is read, is perceived to be its main purpose: "The Congress shall " have power to dispose of and make all needful rules " and regulations respecting the territory or other "property belonging to the United States; and " nothing in this Constitution shall be so construed "as to prejudice any claims of the United States, or "of any particular State." ${ }^{3}$ But, to quote Chief Justice Marshall again: "Whatever may be the "source from which the power is derived, the pos"session of it is unquestioned." 4

Whatever its source, the power of Congress over territory beyond the States is exclusive and complete. The Supreme Court says: "By the Constitu-

${ }^{1}$ American Ins. Co. $v$. Canter, I Peters 511 , 542.

${ }^{2}$ Scott $v$. Sandford, i9 Howard 393, 432-444. See also U. S. v. Kagama, i 8 U. S. 375,380 .

${ }^{3}$ Art. IV, Sec. 3, § 2.

${ }^{4}$ American Ins. Co. $z^{\prime}$. Canter, I Peters 5I I, 544. 
"tion, as is now well settled, the United States, "having rightfully acquired the Territories, and "being the only government which can impose laws "upon them, have the entire dominion and sov" ereignty, national and municipal, federal and State, "over all the Territories, so long as they remain in "a territorial condition." " "Congress may not only "abrogate laws of the territorial legislatures, but it "may itself legislate directly for the local govern"ment. It may make a void act of the territorial "legislature valid, and a valid act void. In other "words, it has full and complete legislative authority "over the people of the Territories and all the " departments of the territorial governments. It " may do for the Territories what the people, under " the Constitution of the United States, may do for "the States." ${ }^{2}$ Although the difference between federal and local affairs is not marked in the Territories by governments organically distinct, as in the States, it exists nevertheless, for Congress stands in a double relation to each Territory, treating it as a part of the republic in matters of federal concern, and caring for its local interests as a State government might.

The local affairs of the Philippines may be administered with as single a regard to their peculiar interests as are the affairs of a State, for the Constitution does not prescribe that all Territories shall be administered from a common standpoint, but permits the peculiar needs of each to be considered. ${ }^{3}$

${ }^{1}$ Shively $v$. Bowlby, 152 U. S. 1,48 .

${ }^{2}$ National Bank $v$. County of Yankton, Ior U. S. 129, 133.

${ }^{3}$ See France $v$. Connor, 16 I U. S. 65. 
In virtue of its powers Congress enjoys a broad discretion in instituting a government for the Philippines. Any form is permissible, from an organization chosen by the islanders to a governor or commission appointed by the President. But a territorial government is essentially subordinate and precarious. Congress remains the sovereign body, and may alter or abolish it at will, and exert superior legislative powers during the term of its existence. The legal right of Congress to establish a territorial government without the coöperation, or even the consent of the people results from the necessary denial of popular sovereignty in the Territories; but this government, however it may be imposed, must rule in conformity to the Constitution.

\section{The Exercise of Congressional Powers}

The current session affords Congress a second opportunity to exert its constitutional powers in the Philippines. These powers should now, and hereafter, be employed sparingly in the direct regulation of local as distinguished from federal affairs, because Congress lacks the knowledge and sympathy essential to the framing of suitable laws for this strange and distant people. The abstention of a national legislature from frequent intervention in the affairs of remote dominions unrepresented in its councils is a notable feature of British policy. "In practice," says Mr. C. F. Lucas, "this paramount power "of legislation by the Imperial Parliament is only "exercised by acts conferring constitutional powers, 
" or dealing with a limited class of subjects of special "imperial or international concern, such as merchant "shipping and copyright. It is therefore, generally "speaking, left to the Crown or to the local legisla"tures to make laws, as Parliament can, when it " thinks fit, make its views on any colonial question "known to the Crown by resolution." 1 Excepting its recognition of executive legislation, the British policy commends itself to us. While all lawful legislation for the Philippines must be congressional, in the sense of being enacted by the agents of Congress and subject to its inherent right of veto, mainly it should be framed by a body in touch with the islands.

A bill carried over from the last session provides " that when all insurrection against the sovereignty " and authority of the United States in the Philippine "Islands, acquired from Spain by the treaty concluded "at Paris on the tenth day of December, I898, shall " have been completely suppressed by the military and " naval forces of the United States, all military, civil, " and judicial powers necessary to govern the said " islands shall, until otherwise provided by Congress, "be vested in such person and persons, and shall be " exercised in such manner, as the President of the "United States shall direct for maintaining and pro"tecting the inhabitants of said islands in the free en"joyment of their liberty, property, and religion."

A precedent for this bill is said to be found in the action of Congress after the annexation of Louisiana. On October $3 \mathrm{I}, \mathrm{I} 8 \mathrm{O}_{3}$, ten days after the exchange of the ratifications of the treaty of cession,

${ }^{1}$ Lucas's Edition of Lewis's Government of Dependencies, p. 33 I. 
Congress passed an act authorizing the President to take possession of Louisiana, and providing "that " until the expiration of the present session of Con"gress, unless provision for the temporary govern"ment of the said Territories be sooner made by "Congress, all the military, civil, and judicial powers " exercised by the officers of the existing government "of the same shall be vested in such person and "persons, and shall be exercised in such manner, as " the President of the United States shall direct for "maintaining and protecting the inhabitants of "Louisiana in the free enjoyment of their liberty, "property, and religion." ${ }^{1}$ The Louisiana Act was followed substantially in the case of Florida ${ }^{2}$ and may have inspired a part of the act annexing Hawaii, ${ }^{3}$ but it is not a precedent for the Philippine bill. The government of Louisiana, such as it was, was established definitely. The Philippine government is to be called into being by the President upon the happening of an event of which he is to be the sole judge - the suppression of insurrection. And, in this relation, the bill is open to the serious objection that it recognizes, tacitly, the mere will of the executive as being the foundation of all governmental powers in the islands. The Louisiana Act continued the old government of Louisiana and merely authorized the President to fill its offices. The Philippine bill enables the President to erect a government at will, manned by "such person and per-

12 Statutes at Large 246.

${ }_{2}^{2}$ Statutes at Large 523. See also Mitchel 7 . U. S., 9 Peters $711,73^{6 .}$

${ }^{3} 30$ Statutes at Large $75^{\circ}$. 
"sons . . . as he may direct." The Louisiana Act did not purport to confer legislative powers upon the President, and Governor Claiborne's first proclamation expressly recognized the obligation of the old laws and municipal regulations. The Philippine bill seems to concede to the President full legislative powers. The Louisiana government was to last no longer than the then session of Congress, though the new government ordained by Congress on March 24, I 804, was not actually installed until October I, I 804. The Philippine government is without term.

Viewing the bill as an Administration measure, and recalling the opinion of the Administration that the Constitution is not law in the Philippines, it seems that it purposes to invest the President with the right, or perhaps I should say to recognize that he has the right, to hold all legislative powers in the islands and exercise them at his pleasure. If this be the purpose of the bill it approves the powers of the British Crown over dependencies not regulated by Parliament, without imposing the checks upon their abuse which obtain in the British system, where the Crown is forbidden to act "contrary to the fundamental law," ${ }^{1}$ and where relief from injustice may be had through an appeal to the Judicial Committee of the Privy Council. ${ }^{2}$

The Philippine bill is a halting measure of doubtful legality. It merely conveys an impression that some day, in some way, something ought to be done for the Philippines, whereas it is the duty of Congress and well within its power to act at once.

1 See supra, p. 3 I.

2 See supra, p. 99. 
Each day of unrest in the Philippines makes our presence more hateful and postpones our opportunity for helpfulness; indeed, if resistance be greatly prolonged we may learn one day that we have demoralized a people we promised to benefit. The republic itself may be menaced by persistent disaffection, for if it shall be involved presently in a new and greater war the enemy will find allies in the Philippine territory. The Administration is blameworthy for having belittled the extent of the disaffection. If the President shall now call for troops to garrison the islands thoroughly he will not be blamed for exaggerating it. But whatever may be the state of the insurrection, the peace we want is contentment - not merely the end of strife; and we cannot hope that one will follow the other whilst we treat disaffection as wanton opposition to a benign sovereign, and armed resistance to our authority as unnatural rebellion.

The attitude of regretful surprise that Filipinos should resist our benevolence is a disingenuous pose. When we recall that a few months ago we knew nothing of the Philippines (know little now in fact), we may comprehend how ignorant must be the islanders of the institutions and spirit of our republic. In these circumstances conciliation is not an improper overture to rebels. It is a generous effort to allay the mistrust of a strange people, and to assure mutual comprehension between parties brought unexpectedly into a difficult relation. In pursuance of these ends let Congress cause proclamation to be made that the Philippines are not a dependency, but are part of the republic and within the protection of the 
Constitution; and especially that citizenship and civil rights are bestowed in the Philippines as in all other United States territory, and that trade between all parts of the republic is free. This proclamation should not be withheld because proclamations of the President and his agents have proved futile, for, as a message from Congress declaring the law of the Constitution, it will be of higher dignity and promise. Nor should it be issued with an exaggerated hope of its influence, since the sending of a message is, after all, but a one-sided dealing at arm's length with a situation that requires intimate discussion. Representative Filipinos should be invited to attend a conference to be held at Washington, and they should be received neither as traitors nor as heroes, but as people of new territory come to discuss the vital question of its government. If it be objected that any intercourse with insurgents is beneath our dignity, let us remember that President Lincoln left his capital to talk with Confederate leaders at Hampton Roads, set in his own opinions, with no expectation of changing theirs, but determined that no chance for peace should be lost through lack of consideration on his part.

OUR RELATION TO THE OLD ORDER

\section{The Old Laws}

One of the first questions suggested by the coming of a new sovereign to a country has regard to the fate of that old order which is evidenced by the local law. In this event, "the law which may be de- 
" nominated political," says Chief Justice Marshall, "is necessarily changed." ${ }^{1}$ This is true in the broad sense that the peculiar attributes and powers of the old sovereign are not transmitted to the new one; nor do the laws through which such powers have been exercised become its laws. "It cannot be ad"mitted," said the Supreme Court, "that the King " of Spain could, by treaty or otherwise, impart to "the United States any of his royal prerogatives; " and much less can it be admitted that they have "capacity to receive or power to exercise them. " Every nation acquiring territory, by treaty or other"wise, must hold it subject to the Constitution and "laws of its own government, and not according " to those of the government ceding it." ${ }^{2} \mathrm{By}$ the light of this decision we perceive that when President Jefferson commissioned a governor of Louisiana with the powers of the former governor-general and the intendant he could not lawfully invest the republican official with any attributes of those representatives of royal power inconsistent with our Constitution. ${ }^{3}$

While the new sovereign has a right to change all the political institutions of the annexed district, Chief Justice Marshall did not mean that the act of annexation necessarily effects this sweeping result; and governmental agencies consistent with the new order may be utilized without confirmatory legislation. The vitality of municipal agencies, for example, is illustrated in the case of California, where the State

${ }^{1}$ American Ins. Co. $v$. Canter, I Peters 5 I I 542.

2 Pollard $v$. Hagan, 3 Howard 2 1 2, 225. See also New Orleans v. U. S., ro Peters 662, 736. See Picton's Case, 30 State Trials 225.

${ }^{3}$ See supra, p. 37. 
courts have even sustained grants of pueblo (town) land made during the existence of the military government by ayuntamientos acting under the old Mexican law. ${ }^{1}$ So the courts of a country are not necessarily closed by its cession. ${ }^{2}$ The Treaty of Paris recognizes this in the provision that civil suits undetermined at the time of the exchange of ratifications may be prosecuted to judgment in the court in which they are pending, or in such court as may be substituted therefor. And the courts of California have affirmed the validity of proceedings in tribunals of Mexican origin acting under the military government. ${ }^{3}$

In regard to civil, as distinguished from political law it is well settled that a system of jurisprudence already established in annexed territory is not supplanted by the system of the acquiring state by the mere act of transfer, but subsists until the new sovereign shall see fit to change it: ${ }^{4}$ And the United States observe both the rule of public law, and the obligations of the Constitution by respecting private property and rights in annexed territory which have become duly vested under the old laws. ${ }^{5}$ Note, however, that the United States are not burdened with obligations in respect of private claims against the

${ }^{1}$ Hart $v$. Burnet, ${ }_{5}$ California $53^{\circ}$, 559. See also Townsend v. Greeley, 5 Wallace 326 .

${ }^{2}$ See Keene $v$. McDonough, 8 Peters 308.

${ }^{3}$ Mena $v$. Le Roy, I California 216; Ryder $v$. Cohn, 37 California 69.

${ }^{4}$ Campbell $v$. Hall, Cowper 204; U. S. $v$. Percheman, 7 Peters 5I, 80; Strother $v$. Lucas, 12 Peters 4 Io, $43^{6}$.

${ }^{5}$ U. S. v. Percheman, 7 Peters 5 I, 86; U. S. $v$. Moreno, I Wallace 400 . 
former government. As the Supreme Court said in regard to the annexation of Mexican territory, the United States took the land, "bound to respect all "rights of property which the Mexican Govern"ment respected, but under no obligations to right "the wrongs which that government had theretofore "committed." 1

Except as they are the foundation of private rights already vested, and compatible with the Constitution, the laws of annexed territory impose no permanent obligation upon the United States. These laws may be divided roughly into three classes.

I. Laws conflicting with the Constitution are null and void. ${ }^{2}$ An interesting recognition of this rule accompanied the transfer of Louisiana to the United States. On November 30, 1803, a French commissioner took momentary possession of Louisiana under the Treaty of San Ildefonso, of October I, I 800 (by which Spain had ceded it to France), only to announce its cession by France to the United States. Pending actual occupation by the United States he revived by proclamation the Black Code ordained by Louis XV during the former rule of France, excepting, however, the provisions inconsistent with our Constitution and laws $;^{3}$ and referring to this Code ${ }^{4}$ we find sufficient reason for the exception in the articles requiring the expulsion of Jews, and the exclusive recognition of the Roman Catholic religion.

${ }^{1}$ Cessna v. U. S., 169 U. S. $165,187$.

${ }^{2}$ See Chicago \& Pacific Ry. Co. v. McGlinn, i 14 U. S. 542, 546.

3 Martin's History of Louisiana, II, I 97.

${ }^{4}$ French's Historical Collections of Louisiana, III, 89. 
2. If an act of Congress extends of its own force to the ceded territory it displaces all laws inconsistent with its provisions. This statement is made rather for the sake of precaution than with a definite suggestion as to its practical bearing, for, while certain acts may be, perhaps, in some sense selfextending, ${ }^{1}$ there has not been established a general rule according to which this quality should be attributed. Certainly self-extending acts must be exceptional, for it is presumed that a legislature enacts a law with regard to the known requirements of the country then within its jurisdiction, and not to the unknown requirements of after-acquired territory. ${ }^{2}$ This presumption is sustained by the common practice of our Government, and by our observance of the rule, just mentioned, that the laws of annexed territory generally subsist until they are definitely superseded - a rule of little value did the general statutes of the United States extend to the territory of their own force.

The doctrines of the self-extension of the Constitution, and of the presumed non-extension of acts of Congress to annexed territory are perfectly reconcilable. The Constitution is an organic law creating a government for the United States, and prescribing fundamental rules for its guidance throughout its dominions. Acts of Congress are laws of lesser dignity. They deal with the circumstantial and varying needs of the republic, and, except where the Constitution prescribes uniformity, the places or

${ }^{1}$ See Cross $v$. Harrison, 16 Howard 164,197 ; Chicago \& Pacific Ry. Co. v. McGlinn, I 44 U. S. $542,546$.

${ }^{2}$ See U. S. $v$. Seveloff, 2 Sawyer $3 \mathbf{1} \mathbf{1}$. 
persons within their purview are necessarily determinable by Congress. When we say that private property in the Philippines cannot be taken for public use without compensation according to the Fifth Amendment, and that at present no one can acquire land there under the Homestead Act, we do not suggest an inconsistency, but attribute to the organic principle and to the circumstantial statute the proper function of each.

3. All other laws of annexed territory stand until changed by the personal or delegated authority of Congress; and the Supreme Court will take judicial notice of them as though they were the laws of a State. $^{1}$

The conduct of Congress in regard to the old body of law will be judged quite as much by the things it leaves untouched, as by its enactments. To point my meaning I cite a recommendation from a report of the Insular Commission on Porto Rico, as being animated by a provincial and destructive spirit from which Congress should be free: "The Spanish "system of laws and procedure," say the Commissioners, "while not all bad, differs so radically in "principle and structure as well as in methods and " forms from our own, that in our judgment the best "way to Americanize Porto Rico is to give them [sic] "the benefit of our complete system." 2 And they recommend the abolition of "all the Spanish laws, "civil and criminal code, code of civil and criminal

${ }^{1}$ Fremont $v$. U. S., I 7 Howard 542, 557 .

${ }^{2}$ Page 6r. (The italics are mine.) 
"practice, and all royal decrees applicable to Porto "Rico," and the substitution of a system based upon what they call "the common law as adopted by the "States of the Union and construed by the courts " thereof."

The sneer at a system of jurisprudence, the greater part of which was devised for Spain and her colonies alike, and has been lately revised ${ }^{1}$ which is akin to the systems of western Europe, and, like these, is founded upon the most enduring work of civilization, - the Roman law, - argues a provincialism and want of judgment that go far toward discrediting the report of the Commissioners as a whole, and the "full "code of laws" they promise to submit.

The proposal to force the common law upon the people of Porto Rico is contrary to the practice of the country whence comes the common law. English colonists going to an uninhabited country take the common law with them as the law of the land ${ }^{2}$ and when they go to a barbarous country they take it as the law for themselves, and for the natives who become members of their community. ${ }^{3} \quad$ But when England extends her sovereignty over a land wherein a civilized system is established she usually accepts it as the basis of law. Thus we find the Roman-Dutch law in Ceylon; ${ }^{4}$ the old French law in Quebec $;{ }^{5}$ the

${ }^{1}$ See Address of Hon. William Wirt Howe, 6o Albany Law Journal ror.

${ }^{2}$ See Falkland Islands Co. v. The Queen, 2 Moore P.C.C., N.S. 266.

${ }^{3}$ See Advocate-General $v$. Ranee Surnomoye Dossee, 2 Moore P. C. C., N. S. 22.

${ }^{4}$ Lindsay $v$. Oriental Bank, 13 Moore P. C. C. 401.

${ }^{5}$ See Exchange Bank $v$. The Queen, ir App. Cas. 157 . 
French Civil Code in Mauritius ; ${ }^{1}$ the old Norman law in Jersey. ${ }^{2}$

Examining the practice of the United States we find that they have carried the common law to sparsely peopled districts in derogation of existing systems - as in the case of the Mississippi territory $;^{3}$ but they have never uprooted the law of an important community. The case of Louisiana is especially instructive: Congress did not supplant the civil law, and, while the people of the Territory soon adopted the common law as the rule in criminal cases, they retained the old law as the basis of their general jurisprudence. And the present Civil Code of Louisiana is described as being "quite like that of "Spain and France, with some provisions, however, " introduced from New York and England. The "code of procedure resembles the procedure of "France and Spain, and is essentially the practice "of the late Roman law adapted to modern con"ditions." 4 The common law supplanted the old system in Florida and California, but not by order of Congress. The inhabitants, acting through a Territorial legislature in one case, and a State legislature in the other, soon changed much of the law to conform to the usage of the dominant race.

The body of Spanish law is partly repugnant to our Constitution, especially in the criminal branch. It may be partly unsuited to the new conditions.

${ }^{1}$ Lang $v$. Reid, 12 Moore P. C. C. 72.

${ }^{2}$ La Cloche $v$. La Cloche, 3 L. R. P. C. 25.

${ }^{3}$ Pollard $v$. Hagan, 3 Howard 2 I $2,227$.

${ }^{4}$ See Mr. Howe's Address above cited. 
Federal courts will administer in the islands, as elsewhere, a general commercial law for the United States; but so far as this Spanish law is the basis of personal and property rights in the Philippines, let it be amended in the interests of the islanders, if need be, not supplanted because it is irksome to a few Americans. In thus respecting the local law we shall act in harmony with the spirit of our Constitution. "In the future growth of the nation," said the Supreme Court, just before the beginning of the late war, "as heretofore, it is not impossible that Con"gress shall see fit to annex territories whose juris"prudence is that of the civil law. One of the con"siderations moving to such annexation might be " the "very fact that the territory so annexed should "enter the Union with its traditions, laws, and "systems of administration unchanged. It would be " a narrow construction of the Constitution to re"quire them to abandon these, or to substitute for a "system which represented the growth of genera"tions of inhabitants a jurisprudence with which "they had had no previous acquaintance or sym"pathy." 1

\section{Language}

The Insular Commission says in its report on Porto Rico: "The official language of the island to "be the English language, but temporarily the "pleadings and proceedings in the first three named “ courts to be called 'Porto Rican' courts may be in "Spanish and in the Federal and Supreme Courts in

${ }^{1}$ Holden $v$. Hardy, ${ }_{169}$ U. S. $366,3^{89}$. 
"English. An official interpreter shall be provided "for each court." 1

Naturally, English will be the medium of intercourse between the Federal Government and the governments of the islands, and the official language of the federal courts. But these requirements will not affect the islanders generally, and the inconvenience of translation and interpretation must be accepted as an inevitable result of annexation. But the recommendation that English shall be the "official language of the island" suggests a hardship that perhaps the Commissioners did not intend, and Congress surely will never inflict. "Official "language" in its broad meaning is the language in which a government conducts all the public business, publishes the laws, and communicates with the people through officials of every degree, and it is the language of all documents of record. Now we may hope that the necessary employment of English, the obvious advantage of acquiring it, and the encouragement of our Government will promote its use in Porto Rico and the Philippines, but we should not attempt to force it upon either, directly or indirectly. A just government will respect the mother tongue of a people over whom it assumes dominion. The persistency of mother tongue has overcome most brutal efforts to supersede it.

So far as sweeping changes in law and language would promote the interests of American officeseekers, and the convenience of a few American settlers, they are not worthy of consideration. As they would impose qualifications for local office that

${ }^{1}$ Page 66. 
would exclude islanders generally, and for know ledge of local affairs that would make them strangers in their own country, they are altogether vicious. Yet if these changes be seriously considered, the motive will not be consciously bad, but rather an enthusiastic notion that we ought to "Americanize" the islanders by process of law. Whereas we should rely upon a wise policy and, above all, upon the example and tact of the men who develop it personally to the islanders to lead them to a better estate.

\section{Religious Institutions}

Our attitude toward religious institutions in the annexed territory involves problems of great interest, and some of serious difficulty.

Excepting the self-explaining prohibition of any religious test as a qualification for office, the position of religion under the Constitution is defined by the clause: "Congress shall make no law respecting an " establishment of religion, or prohibiting the free "exercise thereof." "Free exercise" does not mean unbridled license. "It was never intended or sup" posed," said the Supreme Court, "that the Amend"ment could be invoked as a protection against "legislation for the punishment of acts inimical to "the peace, good order, and morals of society" ${ }^{1}$ and so the Mormon Church was not permitted to plead polygamy as a protected tenet of religion. Whether the Mohammedans of Sulu would have a

${ }^{1}$ Davis $v$. Beason, 133 U.S. 333,342 . See also Mormon

Church v. U. S., I3 I U. S. 1 . 
legal right to object to an act of Congress forbidding polygamy I do not discuss, because its abolition should be sought through moral influences and not by repressive laws. The sufficient reason for distinguishing polygamy in Sulu from polygamy in Utah is that the Mohammedans are, like our tribal Indians, a separate people, a peculiar community who may maintain this traditional institution without affecting the great community of the republic. Our Government, however, has the right to forbid practices so brutal that no plea can be permitted to excuse their perpetration, and it has sometimes exercised this right in the case of tribal Indians.

The provision that Congress "shall make no law "respecting an establishment of religion" plainly forbids all legislation in support of ecclesiastical work and instruction, but lately it has been decided that Congress may appropriate money for hospital buildings for the reception of poor patients at the public charge, the hospital being a secular corporation under the management of a Roman Catholic sisterhood. ${ }^{1}$

Whether this provision operates to dissolve a relation between church and state existing in territory prior to its annexation has never been determined judicially, but this is its accepted and true effect, because under the new régime the state cannot perform the duties imposed by such a relation. The Roman Catholic Church no longer enjoys in our new possessions exclusive recognition, nor a right to aid from the state, though, perhaps, under the rule

${ }^{1}$ Bradfield $v$. Roberts, I 75 U. S. 29 I. 
in Bradfield $v$. Roberts, assistance may be given to worthy public charities managed by religious organizations.

The critical ecclesiastical question in our new possessions concerns the friars in the Philippines. While awaiting full information for a thorough understanding of this question, the fact of discontent with the friars is patent enough to justify some comment and suggestion.

Any discontent caused by the exercise of temporal power, or by the influence of a privileged class, should disappear with the divorce of state from church, and the abolition of class privilege. Discontent arising from any abuse of spiritual power involves ecclesiastical matters placed by our law beyond state interference.

The possession of large tracts of land by the friars seems to be the main source of their power, and it is charged that they have not a valid title to the greater part of their holdings. This, I believe, is the first time the United States have been confronted with so serious a question of this kind in new possessions, the mission lands in California having been readily determined to be held in trust for the public because Mexico had secularized them prior to the cession. ${ }^{1}$ A clause in the Eighth Article of the Treaty of Paris has been criticized, on the erroneous supposition that it assures to the Roman Catholic Church the possession of all property in its occupation. In fact, the clause simply affirms the moral,

${ }^{1}$ See U. S. $v$. Cervantes, 18 Howard 553 ; Faxon $v$. U. S., $17 \mathrm{I}$ U. S. 244 . 
and, in our case, the constitutional obligation to respect vested rights of property, leaving open the very question of present interest, whether the friars have a legal title. President McKinley has instructed the Philippine Commission to investigate this question, ${ }^{1}$ though not, as I understand, to adjudicate it, for this can be done only by a competent tribunal. It would seem, however, that Congress might adopt a report of the Commission as the basis of a suit before a regular court. ${ }^{2}$

If after a just settlement of the land question the presence of the friars in the Philippines should be really inimical to the peace of the islands, it is to be hoped that the Church will transfer them to congenial fields and relieve the United States of a vexatious, perhaps an insoluble, problem. Other countries have, at times, found no difficulty in expelling objectionable religious orders and even in confiscating their property, but the United States are bound to respect both religion and property: They are forbidden to interfere at all with the one; they are empowered to take the other only for public use and upon payment of compensation.

${ }^{1}$ See message of December 3, 1900.

${ }^{2}$ See U. S. $v$. Ritchie, ${ }_{17}$ Howard 525 . 


\section{CHAPTER V}

\section{THE ALIENATION OF THE PHILIPPINES}

I have investigated the status of the Philippines, and I find that our title to them is as perfect in law as our title to the city of Washington, and that, like that city, they are part of the United States.

I have investigated the position of the Constitution with regard to the Philippines, and I find that, being a part of the United States, they are within the purview of many important provisions.

I have considered the governing of the Philippines, and I find no want of legitimate power, yet an actual preference for illegitimate power in the intrusion of the President into the domain of Congress.

Mainly, I have written as though there were no question of our renouncing the sovereignty of the islands, for the reason that opportunity for renunciation in no wise excuses us from respecting the status quo and its obligations; yet the technical legitimacy of our possession neither palliates its real offense, nor suggests its permanence. The annexation of the Philippines is not a cross to be borne - which seems to be the best that can be said for it. It is a blunder to be retrieved.

There is a presumption against the propriety of alienating national territory, and this is generally 
conclusive where the territory has been deliberately acquired, or long occupied, or, above all, where it is identified with the rest of the country through national unity and community of interest. These considerations are not pertinent in the case of the Philippines. At the outbreak of the war with Spain the American people neither wished nor expected to annex the islands, and, whatever personal expectations of aggrandizement may have lurked behind the plan of campaign in the East, the Administration, though it will not plead ignorance of a probable opportunity, maintains that aggrandizement was not intended. Indeed, the most common argument for annexation is really an apology: The law of war forced us to the islands; the law of necessity chained us there. Never in our history was so important an acquisition undertaken so lightly, and accomplished with so little pride of achievement. Our occupation of the Philippines is not only of recent date, but for an indefinite period is likely to be merely an armed occupation. Race hatred confronts us. National unity is beyond prophecy. Far from even desiring community of interests, we actually tax the trade between the islands and the mainland, and would view an immigration of Filipinos as an Asiatic plague. Add that the Philippines are not even an outer line of defense, but rather a vulnerable outpost, and are neither the home of American colonists nor the location of American investments, and it is perceived that we are not embarrassed by considerations that usually place alienation of territory beyond the pale of discussion, but may consider freely the questions of right, terms, and expediency. 
The constitutions of some countries forbid any alienation of territory. This prohibition will not stand in the way of a conqueror; and, indeed, throughout this discussion I assume that a ceding state is acting free from the foreign duress that practically effaces domestic law. Nor does it cover a surrender of claims to disputed territory, as appears by the settlement of the boundary controversy between Great Britain and Venezuela, where the latter, though forbidden to alienate territory, accepted an award dismissing certain claims. The purpose of the prohibition seems to be to assure an ill regulated state against loss of territory by the act of improvident or corrupt rulers.

Generally, and invariably among the stronger nations, with the right to acquire land there is, logically, a right to cede it. And voluntary cession is not unexampled: Witness the cession of Louisiana by France to the United States, of Alaska by Russia to the United States, of Java and Heligoland by Great Britain to Holland and Germany respectively, of St. Bartholomew by Sweden to France.

The law makes the Philippines a part of the United States, but it does not compel us to hold them forever. The right of alienation is conceded by the Administration in the agreement with the Sultan of Sulu, which provides that the United States will not sell the Sulu Islands without his consent. The concession is important as showing that, in the opinion of the Administration, the annexation of the Philip- 
pines has not closed discussion as to their future disposition, but the provision itself is derogatory to our sovereignty. We acquired the Sulus from Spain without the consent of the Sultan, and we should not require his permission to dispose of them.

Each country determines for itself the procedure in regard to cession. Some constitutions, that of France among them, require treaties of cession to be submitted to the legislature. ${ }^{1}$ The Judicial Committee of the Privy Council is strongly of the opinion that the treaty-making body of Great Britain - the Crown in Council - has full power to cede territory, ${ }^{2}$ and this seems to be justified by common precedent; nevertheless, in I890, the Crown asked the consent of Parliament before ceding Heligoland to Germany. ${ }^{3}$

The United States have never ceded territory, but in settling international boundaries their treatymaking body has yielded claims to territory; and in the case of the Northeast Boundary the consent of the States interested was obtained. ${ }^{4}$ Should a project of cession affect State land the State's consent must be secured, ${ }^{5}$ but outlying territory the Federal Government is as free to cede, as to acquire without the express consent of the States.

${ }^{1}$ Esmein, Éléments de Droit Constitutionnel, ad Ed. 533.

2 Damodhar Gordhan $v$. Deoram Kanji, I App. Cas. 332, 373.

${ }^{3}$ See Anson, The Law and Custom of the Constitution, The Crown, 2d Ed. 299.

${ }^{4}$ See Moore, International Arbitrations, I, 153 ; Fort Leavenworth R. $v$. Lowe, I14 U. S. 525, 54I.

${ }^{5}$ See Life and Letters of Joseph Story, II, $286-289$, for his own and Marshall's thoughts on the question of cession under the powers to make war and peace. 
As I have found no legal objection to our treatymaking body annexing land without the consent of the House of Representatives, ${ }^{1}$ I find none to its ceding land of its own motion: And territory may be severed, as well as annexed by joint resolution of Congress.

There is no merit in the assertion that recognition of the Constitution in the Philippines, with its consequence of conferring citizenship upon Filipinos, will preclude, legally or morally, our withdrawal from the islands because of its consequence of alienating citizens.

As the extension of sovereignty over territory is a political matter not reviewable by the courts, ${ }^{2}$ so is its withdrawal; and in the latter, as in the former case the exercise of power is not preventable by the inhabitants. ${ }^{3}$ If we chose to accord to Filipinos permission to elect to retain American citizenship it would be coupled with an obligation to migrate hither within a given time, and we could afford to receive the handful of islanders having the disposition and the money to accept the condition.

Morally, the assertion is disingenuous. There is nothing sacred about a "citizenship" resented by most of its recipients, and begrudged by all its donors.

THE TERMS OF ALIENATION - THE PROTECTORATE

The negotiations which it is to be hoped will effect the rehabilitation of China may disclose a solution of

${ }^{1}$ See supra, p. $6 . \quad \quad{ }^{2}$ See supra, p. 7. $\quad{ }^{3}$ See supra, p. 61. 
our Philippine problem. The perseverance of the United States in their refusal to acquire land in China should not only contribute to a just settlement of this great question of the East, but should enable them to claim the consideration of the Powers for their purposes in regard to the Philippines. At present, however, the result of these negotiations is too uncertain to suggest any definite course for the United States in respect of the Philippines. As now appears, the United States, withdrawing their sovereignty from the islands, will be persuaded to a protectoral relation with a Philippine state.

The President said in his annual message of $1899:^{1}$ "The suggestion has been made that we could "renounce our authority over the islands, and, giving "them independence, could retain a protectorate over "them. This proposition will not be found, I am "sure, worthy of your serious attention. Such an " arrangement would involve at the outset a cruel "breach of faith. It would place the peaceable and "loyal majority, who ask nothing better than to ac"cept our authority, at the mercy of the minority of " armed insurgents. It would make us responsible "for the acts of the insurgent leaders and give us no "power to control them. It would charge us with "the task of protecting them against each other and "defending them against any foreign power with "which they chose to quarrel. In short, it would "take from the Congress of the United States the "power of declaring war and vest that tremendous "prerogative in the Tagal leader of the hour." The humiliating relationship here depicted is a trav- 
esty of a protectorate. A brief examination of the law and custom of protectorates will show that the United States may assume the office of protector without allowing armed insurgents to terrorize peaceable islanders, or permitting an Aguinaldo to whistle the American people to arms.

"Protectorate" is a name for so great a variety of political relationships that it defines none accurately, but a few general observations will suggest the relation I have in view. The protectorate will be founded upon a treaty or agreement with a Philippine state whose organization and fundamental law shall be satisfactory to the United States. I do not mean that we should draft an ideal constitution for the islands as did Locke for the Carolinas, nor commend, as of course, our own as the perfect model; but we must condition our protection upon the adoption of a practicable scheme of government as enlightened as we have a right to expect.

The study of the protectoral relations of other governments will be profitable, but is not likely to suggest a model. ${ }^{1}$ Apart from the Mohammedan districts,

${ }^{1}$ Appendix B contains a few documents illustrating some of the methods by which other nations have assumed more or less authority in territory without formally incorporating it in their dominions. Much of the documentary history of this subject will be found in Le Régime des Protectorats, Brussels, 1899; Aitchison, Collection of Treaties (British India); Holland, The European Concert in the Eastern Question; Hertslet, Map of Africa by Treaty. For the theory and practice of the protectoral relation consult Despagnet, Essai sur les Protectorats; Westlake, Chapters on the Principles of International Law; Hall, Foreign Jurisdiction of the British Crown; Lee-Warner, The Protected Princes of India; Ilbert, The Government of India, Ch. VII. 
which appear to be much like the Protected States of the Malay Peninsula, and may require separate treatment, the Philippines are quite dissimilar from any country now under protection, for we find there a population chiefly of Malay origin whose dominant portion has been Christianized and civilized to a degree by Spanish influence. More importantly, our action must be inspired by uncommon purposes. A protectorate frequently precedes annexation; ours would be the sign of separation. A protectorate is generally a cloak for substantial ownership, but if ownership be our real purpose we must continue to govern the islands constitutionally as part of the United States, and not set up a mock state through which our government may give arbitrary orders to a subject people. A protectorate is usually established without period, though its end may be conditioned upon the happening of an unexpected event; thus, if I may use this case in illustration, it is written that Great Britain shall hold Cyprus until Russia shall surrender Kars. With a clear understanding that our shortcomings at Washington have not necessarily saddled us with interminable responsibilities in the Philippines, our protection should be accorded in the expectation of its withdrawal. Assuming that a protectorate will be declared with a reasonable anticipation that a Philippine state will one day be able to maintain a place among the lesser states of the world, the treaty of protection should fix its own duration.

It is asserted that a Philippine state is impossible, because the Filipinos are incapable of maintaining a 
government. On the other hand we have good evidence of the orderly administration of a great part of Luzon by the insurgent government after the cessation of hostilities in the summer of $1898 .^{1}$ Further evidence of capacity appears in the Report of the First Philippine Commission. The Commissioners describe the Filipinos as being " of unusually promis"ing material"; ${ }^{2}$ "strongly desirous of better educa"tional advantages"; ${ }^{3}$ and say that, after the insurrection has been suppressed, the majority will be found to be "good, law-abiding citizens." ${ }_{4}$ They testify to the marked ability of the educated class, who, "though "constituting a minority, are far more numerous than "is generally supposed, and are scattered all over the "archipelago." ${ }_{5}$ In the matter of government the Commissioners remark a striking likeness between the Filipino ideal and American achievement, going so far as to say that the leading Filipinos have selected "almost precisely the political institutions and "arrangements which have been worked out in prac"tice by the American people; and these are also, "though less definitely apprehended, the political ideas "of the masses of the Philippine people themselves." 6 Finally, the Commissioners cap their appreciation by earnestly recommending for the islands a territorial government substantially of the first class. ${ }^{7}$ It is true that in spite of these tributes to Philippine competency the Commissioners are at some pains to discredit the possibility of establishing a protectorate $;^{8}$ but, like the President, whose views they reflect, they

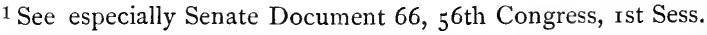
$2 \mathrm{I}$, 120.
4 P. 120.
${ }^{6}$ Pp. 91, 119.
${ }^{8}$ Pp. 99, ro3.
3 P. 4 I
5 P. 120.
7 Pp. I I I, I I 2. 
narrow their consideration of protectorates to the obviously impracticable. And their disapproval must be weighed with due regard to the fact that a recommendation of a method of relinquishing sovereignty, or even an open-minded inquiry for practicable methods, would have been altogether foreign to their official instructions.

The mature opinion of the present Philippine Commissioners is not at hand, but the system of government they are striving to establish would seem to be too advanced for a people really lacking the capacity for organization.

I am not much interested, however, in the taking of testimony in regard to capacity for self-government, because, generally speaking, I do not consider it a fit subject for our adjudication. A nation is not authorized to deny the capacity of an alien people to make its own laws, and the right to live its own life; and rarely does a nation assume this authority except to gloss a purpose of conquest. This is not to say that intervention may not be justified by anarchy or brutal despotism, for in neither case is there a pretense of government by, or for the people.

In the case of the Filipinos we have no right to assume that they cannot, under our temporary protection, organize a government suited to their condition and requirements, and we shall appreciate this truth the moment we abandon the idea that the islands should be held in the interest of American trade. And we may be assured that every generous purpose in regard to the islanders will be more fully developed in a Philippine state, than in a discontented 
American Territory. Indeed, I believe that legitimate trade itself will fare better in the state.

While it would be premature to consider the protectorate in detail, some of its broader features may be suggested.

The Philippine state will not be an exception to the rule that a protected state is never a sovereign among sovereigns. It will not be officially known in the family of nations, for it will hold no relations with foreign states, neither making treaties nor exchanging ministers, nor will it fly a national flag upon the high seas. At most points of contact between the state and the world at large the United States must stand, the advocate of its interests, the defender of its rights. This denial of official foreign intercourse is necessary if only for the reason that as the protector must defend the protected, it must, as far as possible, deprive the latter of opportunity to quarrel with a foreign state by taking into its own strong and competent hands the management of foreign affairs.

Considering that the United States will by protecting a Philippine state assume certain responsibilities in the islands, extending at least to the reasonable protection of foreign interests; and considering that for a time the new state may be unable to preserve, unaided, the requisite order, the United States may reserve the right to keep troops in the islands, and to regulate the composition of a native militia. Thus far we shall perform a mere police duty, undertaken for the common benefit, and requiring only a small force, diminishing as the new state grows in experience. Our own legitimate interests 
will carry us no further. But should foreign nations choose to consider the Philippines as part of the United States ${ }^{1}$ they would be open to attack should we become involved in war, and we must keep a larger force in the islands during the term of our protectorate. To avoid this burden, and also the risk of making the islands the theater of a war in which their people would have no interest, the establishment of a protectorate should be followed by negotiations with the Maritime Powers looking to the neutralization of the Philippines.

A protectorate is not necessarily unconstitutional. Provided it be an honest arrangement, and not a subterfuge for complete control, it is among those foreign relations maintainable by the United States, as well because they are one of the family of nations as by the express contemplation of the Constitution. While the United States have never entered into a relation with another state like that suggested in the case of the Philippines, they have occasionally assumed a protectoral office, notably in respect of the possible routes of interoceanic canals. And our relation to the island of Tutuila is not only distinctly protectoral, but, formerly, was complicated by partnership with Great Britain and Germany in a protectorate over the entire Samoan group.

Our courts have never been required to define the position of the United States in respect of protected territory, but it may be indicated. Bearing in mind that the establishment of a protectorate will mark our relinquishment of territorial sovereignty, it is

${ }^{1}$ See supra, p. I 2. 
perceived that the Philippines will pass straightway from the territorial jurisdiction of Congress to that of the protected state; for, as Mr. Justice Story states the rule, "The laws of no nation can justly extend be"yond its own territories, except so far as regards its "own citizens. They can have no force to control the "sovereignty or rights of any other nation within its " own jurisdiction. And, however general and com"prehensive the phrases used in our municipal laws " may be, they must always be restricted in construc"tion to places and persons upon whom the legis"lature have authority and jurisdiction." 1 Another statement of the Supreme Court will suggest our manner of dealing with the protected state. "By the "Constitution a government is ordained and estab"lished 'for the United States of America,' and not " for countries outside of their limits. . . . The Con"stitution can have no operation in another country. "When, therefore, the representatives or officers of "our government are permitted to exercise authority " of any kind in another country, it must be on such "conditions as the two countries may agree, the laws "of neither one being obligatory upon the other." ${ }^{2}$ This was written of our consular jurisdiction in Japan, now ended by limitation, but it applies to any protectoral relation we may assume toward the Philippines. Upon the establishment of a protectorate, the Federal Government will be no longer the government of the islands. Any influence it may have therein will be exerted in a foreign land by agreement with its sovereign. Our rights under this

1 The Apollon, 9 Wheaton 362,370 .

2 Ross's Case, r4o U. S. 453,464 . 
agreement will be maintained by the President like other treaty rights. Any legislation that Congress may enact in regard to the Philippines will be of an ancillary nature, based upon a general power to provide the means for maintaining the lawful rights and obligations of the United States without regard to locality. This jurisdiction of Congress is not territorial jurisdiction in a foreign country. It is a power to be exercised in furtherance of rights lawfully acquired by the United States in that country. That is to say, Congress cannot impose its will on a Philippine state, because it is the legislature of the United States only, but it may aid in effectuating the rights defined by the treaty of protection. Its aid may take the form of new legislation: for example, an act creating an international court and defining its jurisdiction. More often it will be given by an appropriation of money, a precedent for which is found in the following item inserted for some years in the act making appropriations for the diplomatic and consular service: "For the execution of the ob"ligations of the United States and the protection of "the interests and property of the United States in "the Samoan Islands, under any existing treaty with "the government of said islands and with the gov"ernments of Germany and Great Britain, six thou"sand dollars, or so much thereof as may be necessary, " to be expended under the direction of the President."

I have defined a protectorate on somewhat conventional lines, but with the hope that a better comprehension of conditions may permit even a lighter hand on our part than the comparatively light one I 
have suggested. Indeed, were the islands free from the demoralizing influence of war, we might see our way clear to recognizing a Philippine state needing no protection at home, and finding ample security against foreign conquest in the power of the United States.

\section{THE EXPEDIENCY OF ALIENATION}

The United States, having the right and the opportunity to withdraw their sovereignty from the Philippines, are brought to the question of expediency. Here we are met by the plea that by taking the islands we have given bonds to the world and the islanders to hold them. A perverse guide to conduct! The world has no rights in this domestic matter, and while the interests of the Filipinos should have weight in determining the time and manner of disposing of our territories in Asia, the expediency of disposition must be determined frankly in the interests of the American section of the United States; for, so far as we are entitled to forecast the future of our republic from a study of its past, its strength must forever lie here, not there. With no thought of repudiating our real duties in Asia, with the assurance that these will be best performed by upholding the true ideals of the United States in America, we shall consider the disposition of the Philippines chiefly from the American standpoint.

\section{Commercial Considerations}

First from the standpoint of commerce. The widespread desire for an export trade in something 
besides foodstuffs and a chance surplus of manufactures is a welcome event, though foreign war has only quickened the forces that have been surely pressing us beyond the "home market," so long extolled as the sufficient field for our energies - provided we shut out competitors.

The acquisition of the Philippines being the striking feature of our outward movement, their retention has been assumed, mistakenly, to be essential to its development. Retention of the Philippines has no relation to the bulk of our export trade. During the fiscal years i 898-1900 we exported merchandise to the value of $\$ 3,852,000$, ooo, of which all Asia took but $\$ 157,000,000-$ not very much in excess of the amount taken by Belgium.

Retention of the Philippines is not essential to the very trade so plausibly asserted to depend upon it - the trade of Asia, especially of China. During the fiscal years 1898-1900 our exports to China, including Hong Kong, averaged $\$ 20,000,000$. The potential volume of this export trade is, perhaps, very great, assuming that the affairs of China shall be settled satisfactorily; but we must decline to accept hysterical prophecy about Asiatic trade as our inspiration to duty in the Philippines. It is known that when four hundred million Chinese ${ }^{1}$ buy annually five dollars' worth of foreign goods per head they will buy $\$ 2,000,000,000$ worth; but the date is not set, and were it in sight our industrial community would be aghast in anticipation of the flood of cheap goods coming from China in payment. ${ }^{2}$ It is known

${ }^{1}$ If there are so many.

${ }^{2}$ Sir Robert Hart says: "Many regard China as a far-distant land, 
that by drawing ever-widening circles about Manila ever-widening areas are brought within its reach on the map; but the rulers of Hong Kong, of Port Arthur, of Saigon, of Kiao Chau, of Yokohama may find as much fun and as little profit in playing this nursery game with their own ports for centers. It is known that when merchants the world over send goods for the mainland of Asia to Manila, there unlade and store them, and reship them thence to their destination, Manila will indeed realize the pre-

with an immense population, but so wanting in all that others possess as to be ready to purchase, in unlimited quantities, whatever is offered for sale; whereas, what is true is this: China needs neither import nor export, and can do without foreign intercourse. A fertile soil, producing every kind of food, a climate which favors every variety of fruit, and a population which for tens of centuries has put agriculture, the productive industry which feeds and clothes, above all other occupations - China has all this and more; and foreign traders can only hope to dispose of their merchandise there in proportion to the new tastes they introduce, the new wants they create, and the care they take to supply what the demand really means.

"The sanguine expectations which were expressed when treaties first regulated intercourse, a cycle back, have never been realized. Trade, it is true, has grown, and the revenue derived from it has multiplied; but as yet it is far, far from what our predecessors looked for; and the reason is not that the Chinese Government actively opposed foreign commerce, but that the Chinese people did not require it. Chinese have the best food in the world, rice; the best drink, tea; and the best clothing, cotton, silk, and fur; and possessing these staples, and their innumerable native adjuncts, they do not need to buy a penny's-worth elsewhere; while their Empire is in itself so great, and they themselves so numerous, that sales to each other make up an enormous and sufficient trade, and export to foreign countries is unnecessary. This explains why sixty years of treaty trade have failed to reach the point the first treaty framers prophesied for it."-North American Review, January, igor. 
diction of the Philippine Commission by becoming "the distributing center of the Far East"; but this event must await a discovery that transhipment and storage en route lessen freight charges.

\section{Moral and Political Considerations}

Passing from commercial interests, which do not require the retention of the Philippines, we consider the moral and political obligations of the republic; and these forbid it.

The annexation of the Philippines was accomplished with the supposition that the islanders, with negligible exceptions, would welcome our rule. This supposition was at best a mistaken one, discouraged by the teachings of history, and unsupported by even plausible evidence; and after the annexation the absolute demonstration of its falsity was persistently ignored in official reports and utterances until on October I, I900, General MacArthur made his first report as military governor of the islands. In the course of his report General MacArthur says:

"The Filipinos are not a warlike or ferocious peo" ple. Left to themselves, a large number (perhaps " a considerable majority) would gladly accept Ameri"can supremacy, which they are gradually coming to " understand means individual liberty and absolute "security in their lives and property. The people of "the islands, however, during the past five years have " "been maddened by rhetorical sophistry and stimu"lants applied to national pride, until the power of " discriminating in behalf of matters of public concern 
" or private interest (never very strongly established " among them) has for the time being been almost " entirely suspended. As a substitute for all other "considerations, the people seem to be actuated by " the idea that in all doubtful matters of politics or "war, men are never nearer right than when going " with their own kith and kin, regardless of the nature " of the action, or of its remote consequences.

"This peculiar psychological condition has raised "practical difficulties in obstruction of pacification. "For example, most of the towns throughout the " archipelago, under the advice and control of mili" tary authority, have organized municipal govern" ments, for which kind of local administration the "people have evinced such intelligent capacity as to "encourage the expectation of rapid progress in the " art of self-government when the larger political ad"ministrations are organized.

"The institution of municipal government under "American auspices, of course, carried the idea of " exclusive fidelity to the sovereign power of the "United States. All the necessary moral obligations "to that end were readily assumed by municipal "bodies, and all outward forms of decorum and loy" alty carefully preserved. But precisely at this point " the psychological conditions referred to above began " to work with great energy in assistance of insur"gent field operations. For this purpose most of the " towns secretly organized complete insurgent mu" nicipal governments, to proceed simultaneously and " in the same sphere as the American governments, " and in many instances through the same personnel; "that is to say, the presidentes and town officials 
"acted openly in behalf of the Americans and secretly "in behalf of the insurgents, and, paradoxical as it "may seem, with considerable apparent solicitude for "the interests of both. In all matters touching the "peace of the town, the regulation of markets, the "primitive work possible on roads, streets and "bridges, and the institution of schools, their open "activity was commendable; at the same time they "were exacting and collecting contributions and sup"plies and recruiting men for the Filipino forces, and "sending all obtainable military information to the "Filipino leaders.

"Wherever, throughout the archipelago, there is a "group of the insurgent army, it is a fact beyond "dispute that all contiguous towns contribute to the "maintenance thereof. In other words, the towns, " regardless of the fact of American occupation and "town organization, are the actual bases for all in"surgent military activities; and not only so in the "sense of furnishing supplies for the so-called flying " columns of guerrillas, but as affording secure places "of refuge. Indeed, it is now the most important " maxim of Filipino tactics to disband when closely " pressed and seek safety in the nearest barrio, a "manœuvre quickly accomplished by reason of the "assistance of the people and the ease with which " the Filipino soldier is transformed into the appear" ance of a peaceful native, as referred to in a preced"ing paragraph.

"The success of this unique system of war depends " upon almost complete unity of action of the entire "native population. That such unity is a fact is too "obvious to admit of discussion; how it is brought 
"about and maintained is not so plain. Intimidation "has undoubtedly accomplished much to this end, "but fear as the only motive is hardly sufficient to "account for the united and apparently spontaneous " action of several millions of people. One traitor in "each town would eventually destroy such a complete "organization. It is more probable that the adhesive "principle comes from ethnological homogeneity, "which induces men to respond for a time to the ap" peals of consanguineous leadership, even when such "action is opposed to their own interests and convic"tions of expediency. These remarks apply with "equal force to the entire archipelago, excepting only "that part of Mindanao occupied by Moros, and to " the Jolo group. There is every reason to believe " that all of the Moros are entirely satisfied with ex"isting conditions and are anxious to maintain "them." 1

While General MacArthur indulges in hopes of better things at the beginning of this excerpt and in other parts of his report, he confirms the fact that, excepting the Moros, the islanders are practically united in opposition to American rule; and the satisfaction of the Moros is due to toleration for their barbarous customs, and payment of blackmail to keep them from piracy.

Prattle about the eighty-nine tribes, the character of Aguinaldo, the absence of national feeling, the yearning for American control, the quieting influence of the presidential election, and treasonable sympathy with rebellion no longer diverts us from the

${ }^{1}$ Report of General MacArthur, October I, 1900, Army and Navy Journal, November ro, 1900. 
fact that we are forcing our sovereignty upon the whole Philippine people. And we are compelled to judge this act of the republic of to-day by the principle on which the republic was founded - that governments derive "their just powers from the con"sent of the governed." Petty criticism affects to discover the abandonment of this principle in the acquisition of Louisiana and California without consulting the handful of people living in these vast domains. Disingenuous criticism insinuates a violation in the holding of the Confederate States to their allegiance. But, be it well understood, our conduct in the Philippines involves a flagrant and unprecedented denial - not yet the abandonment - of this vital principle of the Declaration of Independence; and this conduct is not excused by the afterthought that it may precede a higher state of civilization in the islands. Civilization has followed conquest, and so has a new religion, but I believe that enlightened Mohammedans now disavow the propaganda of the sword: And they who affect to view devastation in the Philippines and the Transvaal as a preliminary step toward the higher education of the survivors are but trying to divert attention from blunders that have plunged the great free states of the world into wars for the subjugation of weak peoples.

If, some day, the islanders shall be beaten into subjection, relief at the establishment of order may beget the comfortable reflection that "the end has "justified the means" - a maxim still current among the debased coin of politics. But, considering the permanent welfare of the "republic, the Philippines 
subdued will be quite as undesirable as the Philippines in revolt. The circumstance of revolt merely emphasizes the radical antagonism of this annexation, both to the true mission of the United States in the world and to their best interests at home.

The victory over Spain, especially the dramatic entrance into Asia by way of the Philippines, is made the occasion for boasting that the United States have at last cast off their "swaddling clothes" and taken their place in the world; as if international consequence of a virile and admirable sort had not been theirs from the beginning.

The importance of the United States commenced with their birth in an age when free institutions were practically unknown in continental Europe, and when England had almost forgotten "her precedence in "teaching nations how to live" that Milton had besought her never to forget; and it was not pure coincidence that the establishment of our republic was followed quickly by the French Revolution, from which, through many incidents of loss and gain, the people of continental Europe derive most of the liberties they enjoy to-day. The cause of freedom, encouraged by the founding of the republic, has been fostered everywhere by its success, by its open sympathy, by its prompt recognition of successful rebellion, and, in this hemisphere especially, by its adherence to the Monroe Doctrine. And the United States have borne a notable part in the unselfish activities of civilization; in the advancement of science and the useful arts, in the promotion of respect for 
international law, and in the work of missions and exploration.

The worthiness of our achievements makes it discreditable to belittle them in order to magnify the events of the late war and the sufficiently great opportunities these have disclosed. Far more discreditable is the temptation to use these opportunities as a means of becoming what is called, in the jargon of politics, a "world power." To equip itself for effective work as one of the "world powers" the republic must adopt these policies and principles:

I. An unchanging foreign policy of territorial aggrandizement as active as opportunity permits.

This is the cardinal policy of the "world powers." It is based upon the assumption that markets must be enlarged abroad to prevent starvation at home, and that the best way to sell goods is to own buyers. The anticipated consequence of the rule is an appalling struggle for food, after which the descendants of the brutalized survivors will grope their way to a new civilization.

For the United States, the adoption of this policy means the abandonment of temperate friendliness towards all nations, and the substitution of persistent hatred thinly veiled now here, now there by vexatious alliances.

2. A great and increasing display of military power; though this is partly due to dread of invasion, and, in some countries, of revolution.

For the United States this means an armed force far beyond their proper needs in America, for we do not apprehend invasion, and the necessity for a great 
federal army as a constabulary force can only arise through a blind encouragement of conditions breeding discontent.

Probably it would mean also a recasting of our federal revenue system in order to permit the taxation of land and incomes, now impracticable, as we have seen. ${ }^{1}$ Our expenditure in peace on military account, including pensions, has for some time exceeded that of any professedly militant state, and this must be largely increased if we abandon our traditional policies.

3. A selfishness passing the self-interest underlying a sound national policy, and often reaching out to the denial of any rights in weaker nations. This is the mainspring of the policy of aggrandizement.

These are some of the policies of the world powers, yet one who condemns them is not called upon to impute injustice to all their purposes (Russia, for example, must make her way to an open sea), or, in fine, to unravel the mixed motives and the confused processes that have accompanied notable advances in civilization. But when the best has been said for these policies, they remain unfit for our adoption; and if it be argued that we may keep the Philippines without accepting the policies, I reply that by our conduct in the Philippines we have adopted some of them experimentally, and must employ all of them permanently and in larger measure if we remain in the islands. For if we keep the Philippines we shall not place our Terminus there. They will be but a stage on a march to the mainland of Asia, to be resumed some day, notwithstanding the rational ideas that at

${ }^{1}$ See supra, p. 85 . 
present commend to us the preservation of the state of China.

Withdrawal from the Philippines will mean that, having tried the policies of the "world powers" and found them wanting, we purpose to put our strength to better use than conquest, to affirm the hope of a better law for the world than the law of war, and to invigorate this hope in all nations by the example of our own. And our action will restore to our primacy in America the moral weight it has lost through aggrandizement in Asia, for the Monroe Doctrine, in which we demand the exemption of the Western hemisphere from foreign conquest, has been more conscientiously maintained at home and more respected abroad because of our traditional policy of abstaining from conquest in the Eastern.

Withdrawal from the Philippines will reëstablish the truth that the strength of our republic is not maintained by mere enlargement of boundaries, nor by mere addition of peoples: It is founded upon the competency and loyalty of the civic body, and upon the "indestructible union of indestructible States." 



\section{OBSERVATIONS ON THE STATUS OF CUBA}





\section{OBSERVATIONS ON THE STATUS OF CUBA}

The status of Cuba since the ratification of the Treaty of Paris is anomalous. Viewed as a whole it might be called unique, could this distinction be safely applied to any political condition.

The first paragraph of the First Article of the Treaty of Paris reads: "Spain relinquishes all claim "of sovereignty over and title to Cuba." Here is a parting with territory by Spain, yet there is no cession, nor even a surrender in the sense of a transfer. At the end of the peace negotiations Spain did what at their commencement she protested could not be done; she abandoned Cuba, after vainly striving to induce the United States to accept it from her hands. Yet the island, though abandoned, did not become a derelict, being straightway occupied, although not annexed, by the United States.

In these circumstances Cuba remains as foreign to our domestic system as it was when under the dominion of Spain. It is not within the purview of the Constitution, nor of any law of the United States; nor within the territorial jurisdiction of Congress, for this is the legislature of the United States, and not of This paper is reprinted, somewhat revised, from Yale Law Journal, June, 1900, with the permission of the editors. 
any other country. This limitation of congressional power is prescribed by the rule that the acts of a legislature have no force in foreign territory, except, of course, as they may be held to affect citizens abroad. This rule is sometimes stated in terms recognizing the inability of one state to depreciate the sovereignty of another by asserting jurisdiction in the latter's territory, and were this the whole reason for the rule there might be difficulty in applying it to Cuba, where there is no sovereignty to be depreciated. But the sufficient reason for the rule is that a legislature is without territorial jurisdiction beyond the limits of the country in which it is sovereign. ${ }^{1}$

The second paragraph of the First Article of the Treaty of Paris reads: "And as the island is, upon "its evacuation by Spain, to be occupied by the "United States, the United States will, so long as "such occupation shall last, assume and discharge "the obligations that may, under international law, "result from the fact of its occupation, for the pro"tection of life and property."

In considering the nature and effect of this occupation from the standpoints of the different parties interested in Cuba we shall gain an approximate idea of the status of the island.

From the standpoint of the United States Cuba is a foreign country in our occupation and control.

The occupation is not beneficial to us, as it would ${ }^{1}$ See supra, p. 24. 
be, presumably, had we annexed the island. In fact, it is decidedly burdensome, a vexatious result of a costly war waged for the avowed purpose of freeing Cuba from Spain in order to turn it over to its own people. However this fact may be esteemed in foreign chancelleries, or in Cuba itself, it entitles the United States to assert, upon occasion, any right, privilege, or immunity that enures to a disinterested occupant of territory as distinguished from a sovereign proprietor, and leaves them responsible only for the discharge of the specific obligations of the Treaty of Paris, and such duties, sufficiently onerous, as may be attached by international law to an occupation of this peculiar kind.

Our control over Cuba savors of the protectoral relation in many respects, yet it is not a formal protectorate, because, apart from uncivilized regions, the subject of this relation is a state of more or less substantial powers.

There is no sovereign state of Cuba, and we shall only add to the embarrassments of a sufficiently difficult problem by relying upon such fictions as an embryo state, or an effective sovereignty in the Cuban people. It is true that municipal and provincial systems of government are in operation in the island, and a complete judicial system, all officered by Cubans, but these agencies do not emanate from a local sovereignty; they exist by the ordination or permission of the United States. To be short, whatever real sovereignty there is in Cuba to-day is vested in the representatives of the United States who administer the government of Cuba. Cuba can 
be called a "state" only as the term may be used to dignify a community having a certain standing of its own, yet lacking even the trappings of sovereignty. ${ }^{1}$

The government of Cuba is, really, the President of the United States, the island being ruled by his subordinates who execute his orders, or their own, which he adopts if he does not revoke. It cannot be said that this government is independent, organically, of the United States, for the President enjoys his powers by virtue of his office, and in no respect, either within or without the United States, is that office separable from the Federal Government of which it is a coördinate branch. The government of Cuba is rooted in Washington, not in Havana. It is an offshoot of the executive department of the United States, projected into and holding its place in a foreign territory with the assent of Congress. Hence, although the island of Cuba is not within the jurisdiction of Congress, the government of Cuba is subject to certain powers which the federal legislature is authorized to exert in regard to the executive department.

Whether Congress is competent to order this government to pass specific laws for the island, and thus legislate effectively for it through the medium of the executive department without bringing it, technically, within congressional jurisdiction, I do not discuss. The impropriety of this action should be a sufficient reason for avoiding it.

Our control over Cuba may be called "military" in view of its origin, the agencies by which it is 
chiefly managed, and its freedom from the restraints of municipal law, yet it is not properly identified with a military occupation of conquered territory contemplated by the laws of war. Our control should be, as it is, exerted less rigorously than a "military occupation," and in thus differentiating it I rely upon the persuasive ethics of international law which discourage the application of the law of belligerent right to a peaceful country. And Cuba is at peace, though prudence may forbid at present the withdrawal of our forces, and, if need be, the government is competent to exercise full military powers in the face of insurrection. I say "insurrection" advisedly, because at the moment our government was established in Cuba it rightfully demanded the obedience of the people.

While our control is less onerous than an ordinary military occupation its activities are more varied, and its responsibilities are heavier.

The conqueror's strict duty to the inhabitants of the territory is performed when he affords them such liberty of action and protection as the exigencies of honorable warfare permit. Our duty in Cuba is to guide a friendly country to promised independence.

The fourth clause of the Joint Resolution of Congress, April 20, I 898, reads: "The United States "hereby disclaims any disposition or intention to ex" ercise sovereignty, jurisdiction or control over said "island except for the pacification thereof, and as"serts its determination when that is accomplished to "leave the government and control of the island to its "people"; and this was incorporated in the ultimatum 
forwarded to Spain. "Pacification" is the master word of the first part of the clause, and did this express a self-imposed law, we have broken it, for after stretching the word to the uttermost, many of our acts in Cuba are hopelessly beyond its meaning. For example, the pacification of Cuba is not promoted by orders regulating the sponge fishery, ${ }^{1}$ and prescribing that civil marriages only shall be legally valid. ${ }^{2}$ The truth is "pacification" did not prefigure the broad responsibilities and the sequent powers of the United States in taking charge of Cuba, and so far from breaking faith by assuming, temporarily, complete control, they have performed a function justified by circumstances, though sometimes, as in the marriage law, they have abused their power.

The government of Cuba is not bound by any law of the United States in its dealings with the people, nor by any law of the old régime which it may choose to alter or repeal. Yet, although it is not restrained by a municipal constitution of which the governed may take advantage, I should hesitate to define this government as despotic in theory, not merely for sentimental reasons, but rather because it is required by principle as well as by treaty to respect the dictates of international law.

This government, however defined, is charged with the duty of administering Cuba and abating some grosser evils of the Spanish régime: and perhaps there is a field for remedial action beyond these imperative duties. But zeal for reform, a preference for the American way, which we understand, over the Spanish way, which we do not understand, do not ${ }^{1}$ General Brooke's Civil Report, I, ıо9.

2 Id. 44 . 
justify disturbances of fundamental law and inveterate custom unbecoming the office of a provisional ruler.

Our occupation is terminable at our discretion; and within our power is the method of ending it, though the way of abandonment is practically out of the question.

The United States may end the present occupation by changing its character to sovereign proprietorship - by annexing the island. This can be accomplished by Congress only; the treaty-making body, which usually enlarges the United States, being without jurisdiction in this case, because there is no local government competent to make a cession.

Annexation by formal act would be the orderly course, but might not the same result be reached by Congress legislating for the island? We are so accustomed to enlarge our dominion by formal consent of the titular sovereign of the desired territory that we are apt to lose sight of the truth that land may be annexed as well by occupation, followed by the actual assumption of jurisdiction by the President and Congress. "Who is the sovereign, de jure or de "facto, of a territory," says the Supreme Court, "is not "a judicial but a political question, the determination " of which by the legislative and executive depart"ments of any government conclusively binds the "judges, as well as all other officers, citizens, and "subjects of that government. This principle has "always been upheld by this Court, and has been " affirmed under a great variety of circumstances." 1 And Chief Justice Marshall said: "If those depart-

$$
{ }^{1} \text { Jones } v . \text { U. S., I3I U. S. 202, } 2 \text { I } 2 .
$$


"ments which are intrusted with the foreign inter"course of the nation, which assert and maintain its " interests against foreign powers, have unequivo"cally asserted its rights of dominion over a country " of which it is in possession, and which it claims " under a treaty, if the legislature has acted on the "construction thus asserted, it is not in its own " courts that this construction is to be denied. A "question like this respecting the boundaries of " nations is, as has been truly said, more a political "than a legal question, and in its discussion the "courts of every country must respect the pro" nounced will of the legislature." 1

The principle of Marshall's opinion covers a broader field than the disputed boundaries of land ceded by treaty, which was the case in Foster $v$. Neilson. If the army of the United States seizes foreign land; if a treaty of peace does not mention hostile territory then occupied by our forces, thereby recognizing our possession by the operation of the principle of uti possidetis; if American officers take possession of unoccupied land in the name of the republic, Congress, by legislating for these territories, may effect their incorporation in the United States. Now Congress is at present without jurisdiction in Cuba, but the island is in possession of our forces. If, then, Congress shall choose to make laws for Cuba, the legislative and executive departments of our government will have asserted the perfect sovereignty of the United States, and the

${ }^{1}$ Foster $v$. Neilson, 2 Peters 253 , 309; cited in U. S. $v$. Lynde, ir Wallace $63_{2}, 638$. 
courts will follow their lead, provided the assertion be unequivocal.

Of course our courts would not recognize a statute of doubtful range as extending to Cuba. They would endeavor to construe a statute evidently intended to be operative in the island as an exertion of exterritorial power over our citizens abroad, and not a law of the place; and, though this suggests a most delicate question, it is possible that a statute plainly directed to Cuba might be so trivial in itself, or so markedly at variance, with the pronounced attitude of Congress, that the court would properly treat it as ultra vires, rather than infer the tremendous consequence of an enlargement of the United States from such doubtful evidence of intention.

The method by which the United States are pledged to end their occupation of Cuba is to recognize a Cuban state. It is predicted that the pledge will be broken, or falsely kept by setting up a toy state that will formally cede the island to us. Of these political forecasts I have only to say, at present, that I have yet to see the reason why the pledge should not be kept, and I refuse to believe that the United States will play an hypocritical trick to gain an end which, if improper, should not be pursued, and, if proper, should be gained by the straightforward method of annexation by act of Congress.

\section{III}

From the Cuban standpoint the island is in a singular position. Severed from Spain; not joined 
to the United States; not the territory of a Cuban state, Cuba is, in some sense, merely a region administered by a foreign master.

Yet although the island is not the seat of a sovereign state it possesses a marked characteristic of an organized society - a body of law. Spanish in origin, yet retaining its vitality after the withdrawal of Spain; alterable by the government we have established, yet never becoming United States law, this body is the law of the place, and the fact of its existence makes Cuba to some extent a political entity. To this law of the place, both civil and criminal, all persons in Cuba are amenable, including all foreigners except those whose connection with our army may warrant their subjection to the military laws of the United States.

What is the status of the people of Cuba, including in this class the Peninsular subjects of Spain who have not elected to retain Spanish citizenship in conformity with the provision of the Treaty of Paris?

On April 20, I898, Congress resolved "That the "people of Cuba are, and of right ought to be, "free and independent." In point of law, this resolution had no more effect in Cuba than a resolution "That the Sultan of Morocco has and ought to have "but one wife" would have in his palace. In point of fact, the resolution, so far as it dealt with the existing order of things, did not express a truth at the date of its passage - indeed, in the same breath Congress practically resolved to go to war with Spain because the Cubans were not free and independent. 
Nor are they free and independent to-day, except as they are released from the power of Spain.

The Cubans are no longer subjects of Spain. Divested of Spanish nationality, by their own consent in the case of Peninsulars who have cast their lot with Cuba, by the act of Spain in the case of Cubanborn subjects who were not given a right of election, they can be reintegrated only by complying with the provisions of Spanish law. The situation of men of Cuban birth who prefer Spanish citizenship is, indeed, a hard one, yet they cannot question the legality of the rupture of the old allegiance, for with the right of a sovereign to cede territory is coupled the right to disavow further responsibility for its inhabitants.

The Cubans are not, of course, citizens of the United States; nor are they technically our subjects, though if they owe a qualified allegiance to any political head it is to the government we have set over them. They have been called "citizens of "Cuba," and so long as we understand their citizenship to be of that imperfect kind that does not involve membership in the community we call a sovereign state, we may accept this classification, which seems to be approved by the Treaty of Paris. The Ninth Article declares that if the Peninsular subjects of Spain residing in ceded or relinquished territories shall not within a certain time declare an intention to retain their allegiance, "they shall be held to have re"nounced it, and to have adopted the nationality of the "territory in which they may reside." "Nationality" is evidently used in a political sense, and in order to give effect to this meaning in Porto Rico and the 
Philippines we must assume that the persons mentioned adopt the nationality of the United States, because, as the United States have annexed these islands, it would be as absurd to speak of Porto Rican or Philippine nationality as of Alaskan or New Mexican nationality. ${ }^{1}$ But as the United States have not annexed $\mathrm{Cuba}$, we can give effect to the provision in its regard only by accepting the theory of a Cuban nationality for what it is worth.

A familiar principle of public law is that a radical change of government, however it may alter the public order of things, shall, of itself, affect private relations and rights as little as possible.

The application of this principle to the domestic affairs of Cuba does not call for special consideration. It is sufficient to observe that rights vested under the old laws are not abrogated; that the old laws themselves endure except as they may be altered by the provisional government; and that the people must receive from this government protection to person and property. Beyond these domestic affairs there are interests growing out of the intercourse between Cuba and the world at large, and to these the principle should be applied wherever practicable. Cuba is still within the domain of private international law, and I assume that the courts of foreign nations, including, of course, our own, will generally continue to apply their rules in international controversies, involving contracts, wills, marriages, and the like, as though the island had not undergone a political change. 
Whether a foreigner may sue a person in the courts of the latter's country depends upon the local law, and it will be assumed that foreign tribunals, heretofore open to Cuban subjects of Spain, will not be closed to Cuban protégés of the United States. It is especially important that Cubans shall not lose any privileges in American courts because the United States have placed them in an anomalous position, and where proof of alienage is sufficient to confer jurisdiction there will be no question as to the propriety of entertaining their suits, for unquestionably they are aliens. Because the right to sue is accorded by the Constitution of the United States " to "citizens or subjects of a foreign state," an effort has been made to bar Cubans from the federal courts; but Judge Lacombe has decided in their favor, saying of the defendant's contention: "There is "certainly nothing in all this which lends any color "to the proposition that the plaintiff is not a foreign "citizen. Even the brief memorandum of opinion in "Stuart v. City of Easton, ${ }^{1}$ gives no support to "demurrant's contention. One may be puzzled to "determine upon what theory it was held in that " case that a 'citizen of London, England,' is not "a 'foreign citizen'; but assuming, as suggested, "that it is because London is not a free and indepen" dent community, but owes allegiance to the British "Crown, the decision has no application to the case "at bar, since the political branch of this govern"ment has found as a political fact that the people of "the island of Cuba are 'free and independent." ${ }_{2}$

${ }_{1}^{1} 56$ U. S. $46 . \quad{ }^{2}$ Betancourt $v$. Mutual Reserve Fund Life Association, ror Federal Rep. 305 . 
May not Judge Lacombe's conclusion be upheld without lending judicial sanction to the fiction of Cuban independence? Even if we attribute to Cubans a sort of citizenship they are neither citizens nor subjects of a "foreign state," for there is no "state" of Cuba. As the letter of the Constitution must be somewhat overtaxed in order to cover the case of Cuba, why should not the provision be interpreted, as a whole, in the broad spirit which animates it, and our courts be declared open to persons who show that they are not citizens of the United States?

Besides international controversies determinable in the courts, there are private interests recognized by the law and custom of nations as being the proper subjects of diplomatic assistance or negotiation, and for which individuals may request the good offices of their government. Regarding the common protection and privileges to which persons in foreign countries are entitled by international law, the diplomatic and consular offices of the United States should be exerted in behalf of Cubans as nearly to the extent of their exertion for our own citizens as the rules of foreign governments and our own permit.

Generally speaking, our concern for Cubans abroad cannot be properly questioned by a foreign government, for these reasons: Because the relation between a state and a person for whom it claims protection is no concern of a foreign state unless it claims him as its own citizen, and we shall not meet this embarrassment, since Spain has completely denationalized her Cuban subjects: Because since 
foreign governments are entitled, as we shall see, to view the United States as the protector of the interests of their subjects in the island, they will not disavow the reciprocal duty of safeguarding Cuban interests in their own dominions.

The fact that Cubans cannot receive United States passports, which are issuable to citizens only, is not especially detrimental. The State Department has approved the issuance of the following consular certificate to an American Indian: "The bearer of this " document is a North American Indian whose name "is Hampa. This Indian is a ward of the United "States, and is entitled to the protection of its con"sular and other officials. He is not, however, en"titled to a passport, as he is not a citizen of the "United States. This consulate has the honor to "request the Russian authorities to grant Hampa all " necessary protection during his stay in Russia, and " grant him permission to depart when he requires "it." 1 The State Department may issue suitable certificates to Cubans,- - probably it has done so already, - and these will be honored abroad as our Indian certificate seems to have been, and as the passports issued by Great Britain to persons not her citizens, but within her protection, are honored. ${ }^{2}$

Whatever rights under Spanish treaties Cubans may have enjoyed abroad as Spanish subjects have been lost by the severance of Cuba from Spain. Whatever rights may be secured to them by the Treaty of Paris are enforceable by the United States, at least during the term of their control. Whether

${ }^{1}$ Hunt, The American Passport, p. I47.

2 See Lee-Warner, The Protected Princes of India, 25. 
the United States shall be disposed to request and be able to secure for Cubans the benefit of treaty rights in foreign lands enjoyed by their own citizens depends upon the nature of the particular right in question. There is no doubt that the benefit of our consular jurisdiction in non-Christian countries should be claimed for Cubans; on the other hand, it would be absurd for the United States to demand for them the fishing rights on the northeast coast secured to the people or citizens of the United States by treaty with Great Britain.

The distinction between Cuba and the United States, which we maintain as a matter of domestic law and policy, is not altogether effective from the standpoint of foreign nations.

When a region is occupied by a foreign state, other states are not necessarily affected by the motive of the occupation, so far as their current intercourse is concerned, and, in their reasonable demand for a visible and responsible head to a country with which they deal, are entitled to treat the occupant as the sovereign for certain purposes. And it is the interest as well as the duty of the occupant to accept the proper responsibilities of the position, because if these be disavowed the country is, practically, without a government, and in this event a foreign state, being unable to protect its lawful interests by negotiation, may employ adequate force.

From the standpoint of foreign nations Cuba is in some sense part of the United States, and the United States accept this conclusion of international law. 
According to the First Article of the Treaty of Paris, already cited, "the United States will, so long " as such occupation shall last, assume and discharge "the obligations that may, under international law, "result from the fact of its occupation for the pro"tection of life and property." While this clause is part of a treaty with Spain, and does not import an agreement with any other nation, it is really but the acknowledgment of an independent obligation to all nations. And it may prove to be an inadequate acknowledgment, for if, perchance, there be any international duty not included in " the protection of "life and property," the United States cannot honorably avoid the consequences of a breach of it by referring to the treaty as the measure of their responsibility.

In considering our duties to foreign nations in regard to Cuba we must first differentiate Spain from the generality in regard to the special agreements made with her in the Treaty of Paris. Apart from the special law of this treaty, by which Spain is particularly bound and benefited, she stands with the other nations in respect of international rights and obligations.

The responsibilities in regard to foreign states cast upon an occupant of hostile territory during war, when inevitable disorder may excuse unavoidable defaults, and when the absent sovereign has still a legal title to the country, and may regain possession by reconquest or treaty, are broader and heavier in Cuba, where order reigns, and whence the former sovereign 
has departed, never to return, leaving the representatives of the United States in occupation.

Without attempting to forecast the possible reclamations that may be made against the United States on Cuban account, it must be understood by the Cubans that should the United States become liable for a pecuniary indemnity they will place the real burden where it belongs. If the injury be caused by the unlawful act or omission of United States citizens, the indemnity should be charged upon the Federal Treasury. On the other hand, an indemnity due on account of the acts of Cubans should be charged to Cuba, and paid either out of insular revenues, or by Cuban obligations which the United States should guarantee to the creditor and enforce against the debtor. 
APPENDIX 


\section{(A)}

\section{JOINT RESOLUTION IN REGARD TO CUBA}

(30 U. S. Statutes at Large $73^{8}$ )

Whereas The abhorrent conditions which have existed for more than three years in the island of Cuba, so near our own borders, have shocked the moral sense of the people of the United States, have been a disgrace to Christian civilization, culminating, as they have, in the destruction of a United States battle-ship, with two hundred and sixty-six of its officers and crew, while on a friendly visit in the harbor of Havana, and cannot longer be endured, as has been set forth by the President of the United States in his message to Congress of April eleventh, eighteen hundred and ninety-eight, upon which the action of Congress was invited: Therefore,

Resolved by the Senate and House of Representatives of the United States of America in Congress assembled,

First. That the people of the island of Cuba are, and of right ought to be, free and independent.

Second. That it is the duty of the United States to demand, and the Government of the United States does hereby demand, that the Government of Spain at once relinquish its authority and government in the island of Cuba and withdraw its land and naval forces from Cuba and Cuban waters.

Third. That the President of the United States be, and he hereby is, directed and empowered to use the entire land and naval forces of the United States, and to call into the actual service of the United States the militia of the several States, to such an extent as may be necessary to carry these resolutions into effect.

Fourth. That the United States hereby disclaims any disposition or intention to exercise sovereignty, jurisdiction, or control over said Island except for the pacification thereof, and asserts its determination, when that is accomplished, to leave the government and control of the Island to its people.

Approved April 20, I898. 


\title{
DECLARATION OF WAR
}

(3o U. S. Statutes at Large 364 )

Be it enacted by the Senate and House of Representatives of the United States of America in Congress assembled,

First. That war be, and the same is hereby, declared to exist, and that war has existed since the twenty-first day of April, anno Domini eighteen hundred and ninety-eight, including said day, between the United States of America and the Kingdom of Spain.

Second. That the President of the United States be, and he hereby is, directed and empowered to use the entire land and naval forces of the United States, and to call into the actual service of the United States the militia of the several States, to such extent as may be necessary to carry this Act into effect.

Approved April 25, 1 898 .

\section{PROTOCOL OF AUGUST r 2, r 898}

\author{
(30 Statutes at Large 1742 )
}

William R. Day, Secretary of State of the United States, and His Excellency Jules Cambon, Ambassador Extraordinary and Plenipotentiary of the Republic of France at Washington, respectively possessing for this purpose full authority from the Government of the United States and the Government of Spain, have concluded and signed the following articles, embodying the terms on which the two Governments have agreed in respect to the matters hereinafter set forth, having in view the establishment of peace between the two countries, that is to say:

\section{ARticle I}

Spain will relinquish all claim of sovereignty over and title to Cuba.

\section{ARTICLE II}

Spain will cede to the United States the island of Porto Rico and other islands now under Spanish sovereignty in the West Indies, and also an island in the Ladrones to be selected by the United States. 
Article III

The United States will occupy and hold the city, bay and harbor of Manila, pending the conclusion of a treaty of peace which shall determine the control, disposition and government of the Philippines.

\section{Article IV}

Spain will immediately evacuate Cuba, Porto Rico and other islands now under Spanish sovereignty in the West Indies; and to this end each Government will, within ten days after the signing of this protocol, appoint Commissioners, and the Commissioners so appointed shall, within thirty days after the signing of this protocol, meet at Havana for the purpose of arranging and carrying out the details of the aforesaid evacuation of Cuba and the adjacent Spanish islands; and each Government will, within ten days after the signing of this protocol, also appoint other Commissioners, who shall, within thirty days after the signing of this protocol, meet at San Juan, in Porto Rico, for the purpose of arranging and carrying out the details of the aforesaid evacuation of Porto Rico and other islands now under Spanish sovereignty in the West Indies.

\section{Article V}

The United States and Spain will each appoint not more than five Commissioners to treat of peace, and the Commissioners so appointed shall meet at Paris not later than October $\mathrm{r}, \mathrm{r} 898$, and proceed to the negotiation and conclusion of a treaty of peace, which treaty shall be subject to ratification according to the respective constitutional forms of the two countries.

\section{Article VI}

Upon the conclusion and signing of this protocol, hostilities between the two countries shall be suspended, and notice to that effect shall be given as soon as possible by each Government to the commanders of its military and naval forces.

Done at Washington in duplicate, in English and in French, by the undersigned, who have hereunto set their hands and seals, the twelfth day of August, 1898 .

$$
\begin{aligned}
& \text { [seal.] William R. Day. } \\
& \text { [seal. } \\
& \text { Jules Cambon. }
\end{aligned}
$$




\section{PROCLAMATION OF THE PROTOCOL}

(30 U. S. Statutes at Large 1780 )

Whereas, By a protocol concluded and signed August r 2, r 898 , by William R. Day, Secretary of State of the United States, and His Excellency Jules Cambon, Ambassador Extraordinary and Plenipotentiary of the Republic of France at Washington, respectively representing for this purpose the Government of the United States and the Government of Spain, the Governments of the United States and Spain have formally agreed upon the terms on which negotiations for the establishment of peace between the two countries shall be undertaken: and,

Whereas, It is in said protocol agreed that upon its conclusion and signature hostilities between the two countries shall be suspended, and that notice to that effect shall be given as soon as possible by each Government to the commanders of its military and naval forces:

Now, Therefore, I, William McKinley, President of the United States, do, in accordance with the stipulations of the protocol, declare and proclaim on the part of the United States a suspension of hostilities, and do hereby command that orders be immediately given through the proper channels to the commanders of the military and naval forces of the United States to abstain from all acts inconsistent with this proclamation.

In Witness Whereof I have hereunto set my hand and caused the seal of the United States to be affixed.

Done at the City of Washington this twelfth day of August in the year of our Lord one thousand eight hundred and ninety-eight, and of the Independence of the United States the one hundred and twenty-third.

William MCKinley.

By the President,

William R. Day, Secretary of State. 


\section{THE TREATY OF PARIS}

(30 U. S. Statutes at Large 1 754)

Treaty of Peace between the United States of America and the Kingdom of Spain. Signed at Paris December 10,1898 ; ratification advised by the Senate February 6, 1899; ratified by the President February 6, I899; ratified by Her Majesty the Queen Regent of Spain March 19, I899; ratifications exchanged at Washington April II, I899; proclaimed, Washington, April II, I899.

By the President of the United States of America

\section{A PROCLAMATION}

Whereas, a Treaty of Peace between the United States of America and Her Majesty the Queen Regent of Spain, in the name of her August Son, Don Alfonso XIII, was concluded and signed by their respective plenipotentiaries at Paris on the tenth day of December, 1898 , the original of which Convention being in the English and Spanish languages is, word for word, as follows:

The United States of America and Her Majesty the Queen Regent of Spain, in the name of her August Son, Don Alfonso XIII, desiring to end the state of war now existing between the two countries, have for that purpose appointed as plenipotentiaries:

The President of the United States,

William R. Day, Cushman K. Davis, William P. Frye, George Gray, and Whitelaw Reid, citizens of the United States; and Her Majesty the Queen Regent of Spain, Don Eugenio Montero Rios, President of the Senate, Don Buenaventura DE Abarzuza, Senator of the Kingdom and ex-Minister of the Crown, Don José de Garnica, Deputy to the Cortes and Associate Justice of the Supreme Court, Don Wencesiano Ramirez de Villa Urrutia, Envoy Extraordinary and Minister Plenipotentiary at Brussels, and Don Rafael Cerero, General of Division;

Who, having assembled in Paris, and having exchanged their full powers, which were found to be in due and proper form, have, after discussion of the matters before them, agreed upon the following articles: 


\begin{abstract}
Article I
Spain relinquishes all claim of sovereignty over and title to Cuba.

And as the island is, upon its evacuation by Spain, to be occupied by the United States, the United States will, so long as such occupation shall last, assume and discharge the obligations that may under international law result from the fact of its occupation, for the protection of life and property.
\end{abstract}

\title{
ARticle II
}

Spain cedes to the United States the island of Porto Rico and other islands now under Spanish sovereignty in the West Indies, and the island of Guam in the Marianas or Ladrones.

\section{Article III}

Spain cedes to the United States the archipelago known as the Philippine Islands, and comprehending the islands lying within the following lines:

A line running from west to east along or near the twentieth parallel of north latitude, and through the middle of the navigable channel of Bachi, from the one hundred and eighteenth (I 8 th) to the one hundred and twenty-seventh ( $127^{\text {th }}$ ) degree meridian of longitude east of Greenwich, thence along the one hundred and twenty-seventh ( 127 th) degree meridian of longitude east of Greenwich to the parallel of four degrees and forty-five minutes $(4: 45)$ north latitude, thence along the parallel of four degrees and fortyfive minutes $(4: 45)$ north latitude to its intersection with the meridian of longitude one hundred and nineteen degrees and thirty-five minutes ( 1 I9:35) east of Greenwich, thence along the meridian of longitude one hundred and nineteen degrees and thirty-five minutes (I I 9:35) east of Greenwich to the parallel of latitude seven degrees and forty minutes $(7: 40)$ north, thence along the parallel of latitude seven degrees and forty minutes $(7: 40)$ north to its intersection with the one hundred and sixteenth ( I I 6 th) degree meridian of longitude east of Greenwich, thence by a direct line to the intersection of the tenth (roth) degree parallel of north latitude with the one hundred and eighteenth (I 18 th) degree meridian of 
longitude east of Greenwich, and thence along the one hundred and eighteenth ( 1 r 8 th) degree meridian of longitude east of Greenwich to the point of beginning.

The United States will pay to Spain the sum of twenty million dollars $(\$ 20,000,000)$ within three months after the exchange of the ratifications of the present treaty.

\section{Article IV}

The United States will, for the term of ten years from the date of the exchange of the ratifications of the present treaty, admit Spanish ships and merchandise to the ports of the Philippine Islands on the same terms as ships and merchandise of the United States.

\section{Article, V}

The United States will, upon the signature of the present treaty, send back to Spain, at its own cost, the Spanish soldiers taken as prisoners of war on the capture of Manila by the American forces. The arms of the soldiers in question shall be restored to them.

Spain will, upon the exchange of the ratifications of the present treaty, proceed to evacuate the Philippines, as well as the island of Guam, on terms similar to those agreed upon by the Commissioners appointed to arrange for the evacuation of Porto Rico and other islands in the West Indies, under the Protocol of August 12 , 1898 , which is to continue in force till its provisions are completely executed.

The time within which the evacuation of the Philippine Islands and Guam shall be completed shall be fixed by the two Governments. Stands of colors, uncaptured war vessels, small arms, guns of all calibers, with their carriages and accessories, powder, ammunition, live stock, and materials and supplies of all kinds, belonging to the land and naval forces of Spain in the Philippines and Guam, remain the property of Spain. Pieces of heavy ordnance, exclusive of field artillery, in the fortifications and coast defenses shall remain in their emplacements for the term of six months, to be reckoned from the exchange of ratifications of the treaty; and the United States may, in the meantime, purchase such material from Spain, if a satisfactory agreement between the two Governments on the subject shall be reached. 


\section{Article VI}

Spain will, upon the signature of the present treaty, release all prisoners of war, and all persons detained or imprisoned for political offenses, in connection with the insurrections in Cuba and the Philippines and the war with the United States.

Reciprocally, the United States will release all persons made prisoners of war by the American forces, and will undertake to obtain the release of all Spanish prisoners in the hands of the insurgents in Cuba and the Philippines.

The Government of the United States will at its own cost return to Spain and the Government of Spain will at its own cost return to the United States, Cuba, Porto Rico, and the Philippines, according to the situation of their respective homes, prisoners released or caused to be released by them, respectively, under this article.

\section{Article VII}

The United States and Spain mutually relinquish all claims for indemnity, national and individual, of every kind, of either Government, or of its citizens or subjects, against the other Government, that may have arisen since the beginning of the late insurrection in Cuba and prior to the exchange of ratifications of the present treaty, including all claims for indemnity for the cost of the war. The United States will adjudicate and settle the claims of its citizens against Spain relinquished in this article.

\section{Article VIII}

In conformity with the provisions of Articles I, II, and III of this treaty, Spain relinquishes in Cuba, and cedes in Porto Rico and other islands in the West Indies, in the island of Guam, and in the Philippine Archipelago, all the buildings, wharves, barracks, forts, structures, public highways and other immovable property which in conformity with law belong to the public domain, and as such belong to the Crown of Spain.

And it is hereby declared that the relinquishment or cession, as the case may be, to which the preceding paragraph refers, cannot in any respect impair the property or rights which by law belong to the peaceful possession of property of all kinds, of provinces, municipalities, public or private establishments, ecclesiastical or civic 
bodies, or any other associations having legal capacity to acquire and possess property in the aforesaid territories renounced or ceded, or of private individuals, of whatsoever nationality such individuals may be.

The aforesaid relinquishment or cession, as the case may be, includes all documents exclusively referring to the sovereignty relinquished or ceded that may exist in the archives of the Peninsula. Where any document in such archives only in part relates to said sovereignty a copy of such part will be furnished whenever it shall be requested. Like rules shall be reciprocally observed in favor of Spain in respect of documents in the archives of the islands above referred to.

In the aforesaid relinquishment or cession, as the case may be, are also included such rights as the Crown of Spain and its authorities possess in respect of the official archives and records, executive as well as judicial, in the islands above referred to, which relate to said islands or the rights and property of their inhabitants. Such archives and records shall be carefully preserved, and private persons shall without distinction have the right to require, in accordance with the law, authenticated copies of the contracts, wills and other instruments forming part of notarial protocols or files, or which may be contained in the executive or judicial archives, be the latter in Spain or in the islands aforesaid.

\section{Article IX}

Spanish subjects, natives of the Peninsula, residing in the territory over which Spain by the present treaty relinquishes or cedes her sovereignty, may remain in such territory or may remove therefrom, retaining in either event all their rights of property, including the right to sell or dispose of such property or of its proceeds; and they shall also have the right to carry on their industry, commerce and professions, being subject in respect thereof to such laws as are applicable to other foreigners. In case they remain in the territory they may preserve their allegiance to the Crown of Spain by making, before a court of record, within a year from the date of the exchange of ratifications of this treaty, a declaration of their decision to preserve such allegiance; in default of which declaration they shall be held to have renounced it and to have adopted the nationality of the territory in which they may reside. [An agree- 
ment of March 29, 1900, extended the time for making declaration for six months after April I I, I900.]

The civil rights and political status of the native inhabitants of the territories hereby ceded to the United States shall be determined by the Congress.

\section{Article X}

The inhabitants of the territories over which Spain relinquishes or cedes her sovereignty shall be secured in the free exercise of their religion.

\section{Article XI}

The Spaniards residing in the territories over which Spain by this treaty cedes or relinquishes her sovereignty shall be subject in matters civil as well as criminal to the jurisdiction of the courts of the country wherein they reside, pursuant to the ordinary laws governing the same; and they shall have the right to appear before such courts, and to pursue the same course as citizens of the country to which the courts belong.

\section{Article XII}

Judicial proceedings pending at the time of the exchange of ratifications of this treaty in the territories over which Spain relinquishes or cedes her sovereignty shall be determined according to the following rules:

One. Judgments rendered either in civil suits between private individuals or in criminal matters, before the date mentioned, and with respect to which there is no recourse or right of review under the Spanish law, shall be deemed to be final, and shall be executed in due form by competent authority in the territory within which such judgments should be carried out.

7wo. Civil suits between private individuals which may on the date mentioned be undetermined shall be prosecuted to judgment before the court in which they may then be pending, or in the court that may be substituted therefor.

Three. Criminal actions pending on the date mentioned before the Supreme Court of Spain against citizens of the territory which by this treaty ceases to be Spanish shall continue under its jurisdiction until final judgment; but, such judgment having been ren- 
dered, the execution thereof shall be committed to the competent authority of the place in which the case arose.

\section{Article XIII}

The rights of property secured by copyrights and patents acquired by Spaniards in the island of Cuba, and in Porto Rico, the Philippines, and other ceded territories, at the time of the exchange of the ratifications of this treaty, shall continue to be respected. Spanish scientific, literary and artistic works not subversive of public order in the territories in question shall continue to be admitted free of duty into such territories for the period of ten years, to be reckoned from the date of the exchange of the ratifications of this treaty.

\section{Article XIV}

Spain shall have the power to establish consular officers in the ports and places of the territories, the sovereignty over which has either been relinquished or ceded by the present treaty.

\section{Article XV}

The Government of each country will, for the term of ten years, accord to the merchant vessels of the other country the same treatment in respect to all port charges, including entrance and clearance dues, light dues, and tonnage duties, as it accords to its own merchant vessels, not engaged in the coastwise trade.

This article may at any time be terminated on six months' notice given by either Government to the other.

\section{Article XVI}

It is understood that any obligations assumed in this treaty by the United States with respect to Cuba are limited to the time of its occupancy thereof; but it will upon the termination of such occupancy advise any Government established in the island to assume the same obligations.

\section{Article XVII}

The present treaty shall be ratified by the President of the United States, by and with the advice and consent of the Senate thereof, and by Her Majesty the Queen Regent of Spain; and the ratifica- 
tions shall be exchanged at Washington within six months from the date hereof, or earlier if possible.

In faith whereof we, the respective plenipotentiaries, have signed this treaty and have hereunto affixed our seals.

Done in duplicate at Paris, the tenth day of December, in the year of our Lord one thousand eight hundred and ninety-eight.

$\begin{array}{ll}\text { William R. Day. } & \text { Eugenio Montero Rios. } \\ \text { Cushman K. Davis. } & \text { B. de Abarzuza. } \\ \text { William P. Frye. } & \text { J. de Garnica. } \\ \text { George Gray. } & \text { W. R. de Villa Urrutia. } \\ \text { Whitelaw Reid. } & \text { Rafael Cerero. }\end{array}$

And whereas the said Convention has been duly ratified on both parts, and the ratifications of the two Governments were exchanged in the City of Washington on the eleventh day of April, one thousand eight hundred and ninety-nine :

Now therefore be it known that I, William McKinley, President of the United States of America, have caused the said Convention to be made public, to the end that the same and every article and clause thereof may be observed and fulfilled with good faith by the United States and the citizens thereof.

In witness whereof I have hereunto set my hand and caused the seal of the United States to be affixed.

Done at the City of Washington this eleventh day of April, in the year of our Lord one thousand eight hundred and ninetynine, and of the Independence of the United States the one hundred and twenty-third.

William McKinley.

By the President,

John Hay,

Secretary of State.

\section{ACT OF MARCH 21, 1899}

(3o U. S. Statutes at Large 993)

Be it enacted by the Senate and House of Representatives of the United States of America in Congress assembled, That for the purpose of carrying out the obligations of the treaty between the 
United States and Spain concluded at Paris on the tenth day of December, anno Domini eighteen hundred and ninety-eight, to become immediately arailable upon the exchange of the ratifications of said treaty, there is hereby appropriated, out of any money in the Treasury not otherwise appropriated, the sum of twenty million dollars.

Approved March 2, 1899 .

\section{( B )}

\section{LEASE OF KIAO-CHAU}

(Blue Book China No. I (I899), p. 69)

\section{Extract from the "Reichsanzeiger" of April 29, r898}

\section{[TRANSLATION]}

The following is the text of the treaty between the German Empire and China respecting the lease of Kiao-chau, which was received in Berlin on the 28 th April, 1898 :

The incidents connected with the Mission in the Prefecture of Tsao-chau-foo, in Shantung, being now closed, the Imperial Chinese Government consider it advisable to give a special proof of their grateful appreciation of the friendship shown to them by Germany. The Imperial German and the Imperial Chinese Governments, therefore, inspired by the equal and mutual wish to strengthen the bands of friendship which unite the two countries, and to develop the economic and commercial relations between the subjects of the two States, have concluded the following separate Convention:

\section{Article I}

His Majesty the Emperor of China, guided by the intention to strengthen the friendly relations between China and Germany, and at the same time to increase the military readiness of the Chinese Empire, engages, while reserving to himself all rights of sovereignty in a zone of 50 kilom. ( 100 Chinese li) surrounding the Bay of Kiao-chau at high water, to permit the free passage of German troops within this zone at any time, as also to abstain from taking any measures, or issuing any Ordinances therein, without 
the previous consent of the German Government, and especially to place no obstacle in the way of any Regulation of the water-courses which may prove to be necessary. His Majesty the Emperor of China, at the same time, reserves to himself the right to station troops within that zone, in agreement with the German Government, and to take other military measures.

\section{Article II}

With the intention of meeting the legitimate desire of His Majesty the German Emperor, that Germany, like other Powers, should hold a place on the Chinese coast for the repair and equipment of her ships, for the storage of materials and provisions for the same, and for other arrangements connected therewith, His Majesty the Emperor of China cedes to Germany on lease, provisionally for ninety-nine years, both sides of the entrance to the Bay of Kiaochau. Germany engages to construct, at a suitable moment, on the territory thus ceded, fortifications for the protection of the buildings to be constructed there and of the entrance to the harbor.

\section{Article III}

In order to avoid the possibility of conflicts, the Imperial Chinese Government will abstain from exercising rights of sovereignty in the ceded territory during the term of the lease, and leaves the exercise of the same to Germany, within the following limits :

(r) On the northern side of the entrance to the bay :

The peninsula bounded to the northeast by a line drawn from the northeastern corner of Potato Island to Loshan Harbor.

(2) On the southern side of the entrance to the bay:

The peninsula bounded to the southwest by a line drawn from the southwesternmost point of the bay lying to the south-southwest of Chiposan Island in the direction of Tolosan Island.

(3) The Island of Chiposan and Potato Island.

(4) The whole water area of the bay up to the highest watermark at present known.

(5) All islands lying seaward from Kiao-chau Bay, which may be of importance for its defense, such as Tolosan, Chalienchow, etc.

The High Contracting Parties reserve to themselves to delimitate more accurately, in accordance with local traditions, the boundaries of the territory leased to Germany and of the 50-kilom. zone 
round the bay, by means of Commissioners to be appointed on both sides.

Chinese ships of war and merchant-vessels shall enjoy the same privileges in the Bay of Kiao-chau as the ships of other nations on friendly terms with Germany; and the entrance, departure, and sojourn of Chinese ships in the bay shall not be subject to any restrictions other than those which the Imperial German Government, in virtue of the rights of sovereignty over the whole of the water area of the bay transferred to Germany, may at any time find it necessary to impose with regard to the ships of other nations.

\section{Article IV}

Germany engages to construct the necessary navigation signals on the islands and shallows at the entrance of the bay.

No dues shall be demanded from Chinese ships of war and merchant-vessels in the Bay of Kiao-chau, except those which may be levied upon other vessels for the purpose of maintaining the necessary harbor arrangements and quays.

\section{Article V}

Should Germany at some future time express the wish to return Kiao-chau Bay to China before the expiration of the lease, China engages to refund to Germany the expenditure she has incurred at Kiao-chau, and to cede to Germany a more suitable place.

Germany engages at no time to sublet the territory leased from China to another Power.

The Chinese population dwelling in the ceded territory shall at all times enjoy the protection of the German Government, provided that they behave in conformity with law and order; unless their land is required for other purposes they may remain there.

If land belonging to Chinese owners is required for any other purpose, the owner will receive compensation.

As regards the reëstablishment of Chinese customs stations which formerly existed outside the ceded territory, but within the $5^{0}$-kilom. zone, the Imperial German Government intends to come to an agreement with the Chinese Government for the definitive regulation of the customs frontier, and the mode of collecting customs duties, in a manner which will safeguard all the interests of China, and proposes to enter into further negotiations on the subject. 
The above Agreement shall be ratified by the Sovereigns of both the Contracting States, and the ratifications exchanged in such manner that, after the receipt in Berlin of the Treaty ratified by China, the copy ratified by Germany shall be handed to the Chinese Minister in Berlin.

The foregoing Treaty has been drawn up in four copies, two in German and two in Chinese, and was signed by the Representatives of the two Contracting States on the 6th March, 1898, equal to the fourteenth day of the second month in the twenty-fourth year Kuang-hsü.

(Great Seal of the Tsung-li Yamên.)

The Imperial German Minister, (Signed) Baron von Heyking.

Li Hung-chang (in Chinese), Imperial Chinese Grand Secretary, Minister of the Tsung-li Yamên, \&ic., \&oc.

Weng Tung-ho (in Chinese),

Imperial Chinese Grand Secretary, Member of the Council of State, Minister of the Tsung-li Yamên, \&્c., \&્c.

\section{CHARTER GERMAN COLONIZATION SOCIETY}

(Hertslet, Map of Africa by Treaty, 2d Ed., I, 303)

Charter of Protection granted to the German Colonization Society, for certain Acquisitions of Territory made by it on the South East Coast of Africa between the Territory of the Sultan of Zanzibar and Lake Tanganyika. Berlin, 17 th February, $\mathbf{1} 885$.

\section{[TRANSLATION]}

His Majesty the Emperor has been graciously pleased to address the following Imperial "Charter of Protection" to the Society for German Colonization for their territorial acquisitions in East Africa :

"We, William, by the Grace of God German Emperor, King of Prussia, make known and ordain as follows: 
"The present Presidents of the Society for German Colonization, Dr. Karl Peters and our Chamberlain Felix, Count Behr-Bandelin, having sought our protection for the territorial acquisitions of the Society in East Africa, west of the Empire of the Sultan of Zanzibar, and outside of the suzerainty ('Oberhoheit') of other Powers, and the Treaties lately concluded by the said Dr. Karl Peters with the Rulers of Usagara, Nguru, Useguha, and Ukami in November and December last, by which these territories have been ceded to him for the German Colonial Society with sovereign rights ('Landeshoheit') over the same, having been laid before us, with the Petition to place these territories under our suzerainty, we hereby declare that we have accepted the suzerainty, and have placed under our Imperial protection the territories in question, reserving to ourselves a right of deciding hereafter respecting any further acquisitions in the same district which may be proved to have been obtained by legal contract by the Society or by their legitimate successors.

"We grant unto the said Society, on the condition that it remains German, and that the members of the Board of Directors or other persons intrusted with its management are subjects of the German Empire, as well as to the legitimate successors of this Society under the same conditions, the authority to exercise all rights arising from the Treaties submitted to us, including that of jurisdiction over both the natives and the subjects of Germany and of other nations established in those territories, or sojourning there for commercial or other purposes, under the superintendence of our Government, subject to further regulations to be issued by us, and supplementary additions to this, our Charter of Protection.

"In witness whereof we have with our Royal hand executed this Charter of Protection, and have caused it to be sealed with our Imperial seal.

"Given at Berlin the 17 th February, 1885 .

"v. Bismarck."

“WILLIAM.

\section{FRENCH PROTECTORATE OVER MADAGASCAR}

(Foreign Relations of the U. S., I886, p. 300)

The Governments of the French Republic and of Her Majesty the Queen of Madagascar, wishing to prevent forever the renewal 
of the differences which have lately arisen, and desiring to strengthen their former friendly relations, have agreed to conclude a convention to this effect, and have named for plenipotentiaries to wit, Mr. Paul Emile Miot, rear-admiral commanding in chief the naval division of the Indian Ocean, and Mr. Salvator Patrimonio, minister plenipotentiary for the French Republic, and General Digby Willoughby, general officer commanding the Malagasy forces and minister plenipotentiary for the Government of Her Majesty the Queen of Madagascar, who, after having exchanged their full powers, found in good and due form, have agreed upon the following articles, subject to their ratification:

(I) The Government of the French Republic will represent Madagascar in all its foreign relations. The Malagasies abroad will be placed under the protection of France.

(2) A resident representing the Government of the Republic will control the foreign relations of Madagascar, without interfering in the internal administration of the country.

(3) He will reside at Antananarivo, with a military guard, and will be entitled to be received in private personal audience by the Queen.

(4) The Malagasy authorities under the Queen will not intervene in questions arising between French subjects or between French and foreign subjects. Actions at law between Frenchmen and Malagasies will be tried by the resident, assisted by a Malagasy judge.

(5) Frenchmen will live under French laws as regards the punishment of crimes and offenses committed in Madagascar.

(6) French subjects may freely reside, travel, and carry on trade throughout the Queen's dominions. They will be entitled to lease for undetermined periods or to take leases for long periods, renewable at the sole pleasure of the contracting parties, land, houses, shops, and all other descriptions of real property, and may freely engage and take into their service, on any footing, any Malagasy subject who may be unhindered by previous engagements. Leases and contracts with work-people will be certified in due form before the French resident and the magistrates of the country, and the strict execution of the provisions of such instruments will be guaranteed by the Government. At the death of a Frenchman who may have been the tenant of any landed or house property, his heirs will have the benefit of the remaining term of the lease concluded by the deceased, with the power of renewing the same. French- 
men will only be called upon for the land tax paid by the Malagasies.

No person shall have access to the property or enter the establishments or houses occupied by Frenchmen, or by any person in their service, except with the sanction of the French resident.

(7) The Queen expressly confirms the guarantees stipulated by the treaty of August 7, 1885 , in favor of liberty of conscience and religious toleration.

(8) The Queen's Government undertakes to pay the sum of I $, 000,000$ francs, to be applied in the settlement of French claims liquidated before the last war, and in compensation for the damages suffered by foreign subjects by reason of that war. The investigation and settlement of these indemnities is left to the French Government.

(9) Until payment in full of the above-mentioned sum French troops will occupy Tamatave.

(Io) No claim will be admitted in connection with the measures taken up to the present by the French military authorities.

(I I) The Government of the French Republic undertakes to lend assistance to the Queen in the defense of her states.

(12) The Queen will continue as heretofore to preside over the internal administration of the whole island.

(I3) In consideration of these engagements, the French Republic agrees to desist from any renewal of its demand for a war indemnity.

(I4) The Government of the French Republic, in order to aid the advance of the Malagasy Government and people on the path of civilization and progress, undertakes to place at the Queen's disposal the military instructors, engineers, professors, and artisan foremen whose services may be applied for.

(I5) The Queen expressly undertakes to treat with good will the Sakalavas and Antankares, agreeably to the information on this subject furnished by the French Government. The Government of the Republic reserves to itself the right of occupying the Bay of Diego Suarez, and of creating there the establishments that it may consider desirable.

(16) The President of the French Republic and the Queen grant a general and complete amnesty, accompanied by the raising of all sequestrations placed upon their property, to their respective subjects, who prior to the conclusion of peace compromised themselves by serving the other contracting party. 
(I7) The actually existing treaties and conventions between the French Republic and the Queen are expressly confirmed in so far as they may not be contrary to stipulations of the present treaty.

(I8) The present treaty has been drawn up in French and Malagasy, the two versions having exactly the same sense, so that the two texts may be legally cited in every respect.

(19) The present treaty shall be ratified within a period of three months.

Made in duplicate on board the Naizda, in the harbor of Tamatave, December I 7 , r 885 .

The rear-admiral commanding in chief the naval division of the Indian Ocean,

E. Miot.

The minister plenipotentiary of the French Republic,

S. Patrimonio.

The minister plenipotentiary of Her Majesty the Queen of Madagascar, general officer commanding the Malagasy forces,

Digby Willoughby.

(Madagascar has lately been formally annexed by France.)

\section{TRANSFER OF MYSORE TO A NATIVE RULER}

(Lee-Warner, The Protected Princes of India, p. I66)

Whereas the British Government has now been for a long period in possession of the territories of Mysore, and has introduced into the said territories an approved system of administration: And whereas, on the death of the late Mahárája, the said Government, being desirous that the said territories should be administered by an Indian dynasty under such restrictions and conditions as might be necessary for ensuring the maintenance of the system of administration so introduced, declared that if Mahárája Chamrajendra Wadiar Bahádur, the adopted son of the late Mahárája, should, on attaining the age of eighteen years, be found qualified for the position of ruler of the said territories, the government thereof should be entrusted to him, subject to such conditions and restrictions as might be thereafter determined: And whereas the said Mahárája Chamrajendra IVadiar Bahádur has now attained the said age of 
eighteen years, and appears to the British Government qualified for the position aforesaid, and is about to be entrusted with the government of the said territories: And whereas it is expedient to grant to the said Mahárája Chamrajendra Wadiar Bahádur a written instrument defining the conditions subject to which he will be so entrusted: It is hereby declared as follows :-

(r) The Mahárája Chamrajendra Wadiar Bahádur shall, on the twenty-fifth day of March, 188r, be placed in possession of the territories of Mysore, and installed in the administration thereof.

(2) The said Mahárája Chamrajendra Wadiar Bahádur, and those who succeed him in manner hereinafter provided, shall be entitled to hold possession of and administer the said territories as long as he and they fulfil the conditions hereinafter prescribed.

(3) The succession to the administration of the said territories shall devolve upon the lineal descendants of the said Mahárája Chamrajendra Wadiar Bahádur, whether by blood or adoption, according to the rules and usages of his family, except in case of disqualification through manifest unfitness to rule.

Provided that no succession shall be valid until it has been recognized by the Governor-General in Council.

In the event of a failure of lineal descendants, by blood and adoption, of the said Mahárája Chamrajendra Wadiar Bahádur, it shall be within the discretion of the Governor-General in Council to select as a successor any member of any collateral branch of the family whom he thinks fit.

(4) The Mahárája Chamrajendra Wadiar Bahádur and his successors (hereinafter called the Mahárája of Mysore) shall at all times remain faithful in allegiance and subordination to Her Majesty the Queen of Great Britain and Ireland and Empress of India, her heirs and successors, and perform all the duties which, in virtue of such allegiance and subordination, may be demanded of them.

(5) The British Government having undertaken to defend and protect the said territories against all external enemies, and to relieve the Mahárája of Mysore of the obligation to keep troops ready to serve with the British army when required, there shall, in consideration of such undertaking, be paid from the revenues of the said territories to the British Government an annual sum of Government rupees thirty-five lákhs in two halfyearly instalments, commencing from the said twenty-fifth day of March, I88r. 
(6) From the date of the Mahárája's taking possession of the territories of Mysore the British sovereignty in the island of Seringapatam shall cease and determine, and the said island shall become part of the said territories, and be held by the Mahárája upon the same conditions as those subject to which he holds the rest of the said territories.

(7) The Mahárája of Mysore shall not, without the previous sanction of the Governor-General in Council, build any new fortresses or strongholds, or repair the defences of any existing fortresses or strongholds in the said territories.

(8) The Mahárája of Mysore shall not, without the permission of the Governor-General in Council, import or permit to be imported into the said territories arms, ammunition, or military stores, and shall prohibit the manufacture of arms, ammunition, and military stores throughout the said territories, or at any specified place therein, whenever required by the Governor-General in Council to do so.

(9) The Mahárája of Mysore shall not object to the maintenance or establishment of British cantonments in the said territories, whenever and wherever the Governor-General in Council may consider such cantonments necessary. He shall grant free of all charge such land as may be required for such cantonments, and shall renounce all jurisdiction within the land so granted. $\mathrm{He}$ shall carry out in the lands adjoining British cantonments in the said territories such sanitary measures as the Governor-General in Council may declare to be necessary. He shall give every facility for the provision of supplies and articles required for the troops in such cantonments, and on goods imported or purchased for that purpose no duties or taxes of any kind shall be levied without the assent of the British Government.

(ro) The military force employed in the Mysore state for the maintenance of internal order and the Mahárája's personal dignity, and for any other purposes approved by the Governor-General in Council, shall not exceed the strength which the Governor-General in Council may from time to time fix. The directions of the Governor-General in Council in respect to the enlistment, organization, equipment, and drill of troops shall at all times be complied with.

(II) The Mahárája of Mysore shall abstain from interference in the affairs of any other state or power, and shall have no com- 
munication or correspondence with any other state or power, or the agents or officers of any other state or power, except with the previous sanction and through the medium of the GovernorGeneral in Council.

(I 2) The Mahárája of Mysore shall not employ in his service any person not a native of India without the previous sanction of the Governor-General in Council, and shall, on being so required by the Governor-General in Council, dismiss from his service any person so employed.

(r3) The coins of the Government of India shall be a legal tender in the said territories in the cases in which payment made in such coins would, under the law for the time being in force, be a legal tender in British India; and all laws and rules for the time being applicable to coins current in British India shall apply to coins current in the said territories. The separate coinage of the Mysore state, which has long been discontinued, shall not be revived.

(14) The Mahárája of Mysore shall grant free of all charge such land as may be required for the construction and working of lines of telegraph in the said territories wherever the GovernorGeneral in Council may require such land, and shall do his utmost to facilitate the construction and working of such lines. All lines of telegraph in the said territories, whether constructed and maintained at the expense of the British Government, or out of the revenues of the said territories, shall form part of the British telegraph system, and shall, save in cases to be specially excepted by agreement between the British Government and the Mahárája of Mysore, be worked by the British Telegraph Department; and all laws and rules for the time being in force in British India in respect to telegraphs, shall apply to such lines of telegraph when so worked.

(r5) If the British Government at any time desires to construct or work, by itself or otherwise, a railway in the said territories, the Mahárája of Mysore shall grant free of all charge such land as may be required for that purpose, and shall transfer to the GovernorGeneral in Council plenary jurisdiction within such land; and no duty or tax whatever shall be levied on through traffic carried by such railway which may not break bulk in the said territories.

(ı6) The Mahárája of Mysore shall cause to be arrested and surrendered to the proper officers of the British Government any 
person within the said territories accused of having committed an offence in British India, for whose arrest and surrender a demand may be made by the British Resident in Mysore, or some other officer authorized by him in this behalf; and he shall afford every assistance for the trial of such persons by causing the attendance of witnesses required, and by such other means as may be necessary.

(I 7) Plenary criminal jurisdiction over European British subjects in the said territories shall continue to be vested in the Governor-General in Council, and the Mahárája of Mysore shall exercise only such jurisdiction in respect to European British subjects as may from time to time be delegated to him by the Governor-General in Council.

(18) The Mahárája of Mysore shall comply with the wishes of the Governor-General in Council in the matter of prohibiting or limiting the manufacture of salt and opium, and the cultivation of poppy, in Mysore; also in the matter of giving effect to all such regulations as may be considered proper in respect to the export and import of salt, opium, and poppy heads.

(19) All laws in force and rules having the force of law in the said territories when the Mahárája Chamrajendra Wadiar Bahádur is placed in possession thereof, as shown in the schedule hereto annexed, shall be maintained and efficiently administered, and, except with the previous consent of the Governor-General in Council, the Mahárája of Mysore shall not repeal or modify such laws, or pass any laws or rules inconsistent therewith.

(20) No material change in the system of administration, as established when the Mahárája Chamrajendra Wadiar Bahádur is placed in possession of the territories, shall be made without the consent of the Governor-General in Council.

(2r) All title-deeds granted and all settlements of land revenue made during the administration of the said territories by the British Government, and in force on the said 17 th day of March, I88I, shall be maintained in accordance with the respective terms thereof, except in so far as they may be rescinded or modified either by a competent Court of law, or with the consent of the Governor-General in Council.

(22) The Mahárája of Mysore shall at all times conform to such advice as the Governor-General in Council may offer him with a view to the management of his finances, the settlement 
and collection of his revenues, the imposition of taxes, the administration of justice, the extension of commerce, the encouragement of trade, agriculture, and industry, and any other objects connected with the advancement of His Highness's interests, the happiness of his subjects, and his relations to the British Government.

(23) In the event of the breach or non-observance by the Mahárája of Mysore of any of the foregoing conditions, the Governor-General in Council may resume possession of the said territories and assume the direct administration thereof, or make such other arrangements as he may think necessary to provide adequately for the good government of the people of Mysore, or for the security of British rights and interests within the province.

(24) This document shall supersede all other documents by which the position of the British Government with reference to the said territories has been formally recorded. And, if any question arise as to whether any of the above conditions has been faithfully performed, or as to whether any person is entitled to succeed, or is fit to succeed to the administration of the said territories, the decision thereon of the Governor-General in Council shall be final.

(Signed) Ripon,

Viceroy and Governor-General.

Fort William, ist March, $\mathbf{1} 88 \mathrm{I}$.

\section{LAGOS PROTECTORATE ORDER IN COUNCIL}

(The London Gazette, January 5, 1900)

At the Court at Windsor, the $27^{\text {th }}$ day of December, 1899 .

\section{Present,}

The Queen's Most Excellent Majesty. His Royal Highness the Duke of Connaught and Strathearn. Mr. Balfour. Mr. Ritchie.

Whereas Her Majesty hath acquired power and jurisdiction within divers countries on the West Coast of Africa, near or adjacent to Her Majesty's Colony of Lagos:

And whereas by an Order in Council bearing date the twentyninth day of December one thousand eight hundred and eightyseven, it was provided that it should be lawful for the Legislative Council for the time being of the Colony of Lagos, by Ordinance or Ordinances, to exercise and provide for giving effect to all such 
powers and jurisdiction as Her Majesty might, at any time before or after the passing of the said Order in Council, have acquired in the said territories adjacent to the Colony of Lagos, subject to such provisions as are in the said Order in Council described and set forth :

And whereas, it is expedient to define the limits within which the powers and jurisdiction of Her Majesty in the said territories under the provisions of the said Order in Council shall in future be exercised.

Now, therefore, Her Majesty, in pursuance of the powers by "The Foreign Jurisdiction Act, $\mathbf{1} 890$," or otherwise in Her Majesty vested, by and with the advice of Her Privy Council, is pleased to order, and it is hereby ordered, as follows :

I. This Order may be cited as the Lagos Protectorate Order in Council, r 899 .

II. Subject to the provisions of the said Order in Council of the twenty-ninth December one thousand eight hundred and eightyseven, the Legislative Council for the time being of the Colony of Lagos may by Ordinance or Ordinances, exercise and provide for giving effect to all such powers and jurisdiction as Her Majesty may, at any time either before or after the passing of this Order, have acquired or may acquire within such of the territories of the West Coast of Africa near or adjacent to the Colony of Lagos as are within the limits of this order.

Provided that nothing in any such Ordinance or Ordinances contained shall take away or affect any rights secured to any natives in the said territories by any Treaties or arrangements made on behalf or with the sanction of Her Majesty, and that all such Treaties and agreements shall be and remain operative and in force, and that all pledges and undertakings therein contained shall remain mutually binding on all parties to the same.

III. The limits of this Order are the territories of Africa bounded by the following line,

Provided always that such parts of territories so bounded as are within that portion of Her Majesty's dominions which is known as the Colony of Lagos, shall not be included within the limits of this Order. The territories within the limits of this Order shall be known and described as the Lagos Protectorate.

IV. This Order shall be published in the Gazette of the Colony of Lagos, and shall thereupon commence and come into operation; 
and the Governor shall give directions for the publication of this Order at such places, and in such manner, and for such time or times as he thinks proper for giving due publicity thereto within the Lagos Protectorate.

And the Right Honorable Joseph Chamberlain, one of Her Majesty's Principal Secretaries of State, is to give the necessary directions herein accordingly.

A. W. Frtz Roy. 


\section{INDEX OF CASES}

\section{AMERICAN}

American Ins. Co. v. Canter, 5, 23, 6I, $63,123,131$

American Publishing Co. v. Fisher, $3^{8}$

Apollon, The, 24, 156

Beard $v$ : Burts, I 7

Betancourt $v$. Life Ass'n, 185

Black $v$. Jackson, $3^{8}$

Bollman's Case, 36 , ror

Boyd $v$. Thayer, 62,63

Bradfield $v$. Roberts, $14 \mathbf{I}$

Brien $v$. Williamson, 34

Callan $v$. Wilson, 38

Capital Traction Co. $v$. Hof., $4^{\circ}$

Cessna v. U. S., 133

Cherokee Nation $v$. Georgia, I5, 94 “ Tobacco, 17

Chicago, etc., R. v. McGlinn, I33, r34

Chisholm v. Georgia, 64

City of Panama, The, 40

Civil Rights Cases, 67

Cohens $v$. Virginia, 82

Cross v. Harrison, 77, 79, 80, 107, 112 ,

Geofroy $v$. Riggs, $\mathbf{1}$ 7, 39

Gibbons $v$. Dist. Columbia, 88

“ $\quad v$. Ogden, 94, 97

Goetze $v$. U. S., 15, 19, 24, 26, 74

Groves $v$. Slaughter, 33, 93, 94

Hart v. Burnet, $\mathbf{r}_{32}$

Headmoney Cases, 16

Holden $v$. Hardy, $\mathrm{I}_{3} 8$

Honomu Sugar Co. v. Zeluch, 69

Hylton v. U. S., 85

Jaremillo $v$. Romero, 69

Johnson $v$. McIntosh, 2, 5

Jones $v$. U. S., 5, 7, 179

Keene $v$. McDonough, $\mathbf{I}_{32}$

Keith $v$. Clark, 98

Knowlton $v$. Moore, 87

Lattimer $v$. Poteet, $\mathbf{1} 7$

Legal Tender Cases, 94

Leitensdorfer $v$. Webb, II I

Lem Moon Sing v. U. S., 59

License Cases, $\mathbf{I} 7$

Loughborough $v$. Blake, $8,40,42,78$, 85,87

Davis $v$. Beason, 140

Doe $v$. Braden, I 7

Elk $v$. Wilkins, 57

Faxon $v$. U. S., 143

Field $v$. Clark, 1 Io

Fleming $v$. Page, 5, 13, 79

Fong Yue Ting $v$. U. S., 16, 40

Fort Leavenworth R. $v$. Lowe, 147

Foster $v$. Neilson, 7, 180

France $v$. Connor, 124

Fremont $v$, U. S., 135

Gassies v. Ballon, 50

Gelston $v$. Hoyt, 7

McAllister $v$. U. S., 40

Marbury $v$. Madison, 47, 99

Martin v. Mott, 109

Maynard $v$. Hill, 30,40

Mena $v$. Le Roy, 132

Milligan's Case, I07

Mitchel $v$. U. S., I27

Mormon Church v. U. S., 40, 7I, 140

Murphy $v$. Ramsey, 40, 7I

National Bank $v$. Guthrie, 38

" " $v$. Yankton, 39, 40, 7I, 124

New Orleans $v$. De Armas, 9, 28

“ " $\quad v$ U. S., I7, I3I

“ " $\quad$. Winter, 39 
Ortiz, ex parte, $3^{8}$

Picton's Case, 131

Pollard v. Hagan, 37, 131, 137

Pollock $v$. Trust Co., 85

Protector, The, 107

Reform, The, 96

Resolution, The, 3

Robertson $v$. Baldwin, 49, 68

Ross's Case, 26, 4I, 50, 76, 156

Ryder $v$. Cohen, 132

Sah Quah's Case, 66

Scott $v$. Sandford, $8,40,70,123$

Sère $v$. Pitot, 122

Shively $v$. Bowlby, $5,{ }_{9}^{8}, 124$

Siebold's Case, ror

Slaughter-house Cases, 40, 53, 69

Snow $v$. U. S., 39

Springville $v$. Thomas, 38

Stoughtenburgh $v$. Hennick, 92

Strader $v$. Graham, $4^{\circ}$

Strother $v$. Lucas, 132

Stuart $v$. Easton, $\mathbf{I} 85$

Talbott $v$. Silver Bow County, 39

Texas $v$. White, $5^{8}$

Thirty Hogsheads of Sugar, 13

Thomas $v$. Gay, 17

Thompson $v$. Utah, $3^{8}$

Townsend $v$. Greeley, $\mathbf{1 3 2}^{2}$

U. S. $v$. Bevans, 24

“ v. Cervantes, 142

“ v. Cruikshank, 55

“ v. E. C. Knight Co., 96

“ข. 43 Gallons of Whisky, 95

“ v. Kagama, 123

“ $v$. Lynde, $\mathbf{1} 80$

“ v. Moreno, 132

“v. Old Settlers, 16

“v. Percheman, 132

“ $v$. Repentigny, 59

“ v. Rice, 13, 79

“ $v$. Ritchie, 143

“ v. Seveloff, 134

“v. The Peggy, 17
U. S. $v$. Wong Kim Ark, 54, 56, 57, 69

“ v. Yorba, 107

Utter $v$. Franklin, 39

Van Horne's Lessee $v$. Dorrance, 47

Ware $v$. Hylton, 17

William, The Brig, 93

Yerger's Case, ror

\section{ENGLISH}

Advocate-Gen. $v$. Ranee Surnomoye Dossee, 136

Anderson's Case, roo

Brown's Case, 2 I

Calvin's Case, 25

Campbell $\%$. Hall, $\mathbf{1} 3,31, \mathbf{I}_{32}$

Damodhar Gordhan v. Deoram Kanji, 147

Dillet's Case, 100

Emperor of Austria $v$. Day, 7

Exchange Bank v. The Queen, 136

Falkland Islands $v$. The Queen, $100, x \leqslant 6$

Foltina, The, 13

Heathfield $v$. Chilton, 6

La Cloche v. La Cloche, $\mathrm{x} 37$

Lang $v$. Reid, 137

Lindsay $v$. Oriental Bank, 136

Natal, Lord Bishop of, 99

Parlement Belge, The, I 7

Phillips v. Eyre, 116

Speaker $v$. Glass, 100

Sprigg v. Sigcau, 100

Stepney Election Petition,' 25

Walker $v$. Baird, 17 


\section{GENERAL INDEX}

Alaska, 9, 22, 36, 37, 66, 8o, 1 I9

Algeria, 64

Alienation of territory (see also Cession)

propriety of, $\mathbf{I} 44$

right of, 146

Allegiance, 24, 52, 63, 64, 183

Alliance, 3

Annexation, right of, 4

method of, $5-7, \mathbf{I}_{3}$

purpose of, 8-10

Annexed territory, status of, $\mathbf{1 2}, 23$

old laws of, 112,130

vested rights in, 132,142

courts of, 132

Anson, Sir William, I Io

Arbitrary power, $37,48,50,73,116$, I98

Asia, 159, 166, 168

Australia, 2I

Belligerent right, I07, 177

Benton, Mr., 37

Bill of rights, 73

Blackburn, Justice, 2 I

Bradley, Justice, 40, 53, 75

Brewer, Justice, 40

Bryce, Mr., 48

\section{Calhoun, Mr., 27}

California, 9, 23, 35, 37, 80, 86, 106, 108, I I $1,116,131,137,142,165$

Canada, $2 \mathbf{I}$

Cession, right of, 26,146 stipulations regarding, 18,23

Chase, Chief Justice, 107

China, 148, I 59

Chinese, 59, 68

Citizens, natural-born, 52 naturalized, 63

Civil law, 138 rights, Io, $7 \mathbf{I}$

Civil War, the, 4, 51, 58, 96, 98, 107, I20, 130, 165

Clifford, Justice. 40
Coaling stations, 8

Cockburn, Chief Justice, 2I, I00

Commerce, federal power over, 90-98

domestic-

taxation of, 78

embargo on, 91

foreign, 158,161

taxation of, 76

Commercial unity of United States, 78 , $82,91,102,104,130$

law of United States, 138

Congo State, 24

Congress -

subordinate to Constitution, 29

distinguished from Parliament, 45, 47 depository of legislative power, I IOI2I

territorial jurisdiction of, 24, 25, 27 , 108, 121, 157, I 73, 176, I8o

power over Territories, 7o, 88, 89, I 2 I-I 30

annexation by, $7,13,180,181$

alienation by, 148

abrogation of treaty by, 16

purview of acts of, 134,18 I

Conquest, 104, I67

title by, 5,13

effect of, on treaty-making power, 16 , I9, 147

Consent of the governed, $12,60,165$

Constitution of U. S.-

the foundation of U. S., 45

inherent force of, 29, 102, I34

the source of authority, 46

ineffective beyond U. S., $50,76,15^{6}$, I 73

theory of geographical limitation, 34

theory of restriction to States, 35, 66, 78

amendment of, 105

effect of, in annexed territory, $, 88, \mathbf{1}_{4} 8$

effect of withholding, 103

subordination of treaties to, 17,20

1 $3^{\text {th }}$ Amendment of, 16 
Constitution of U. S. (continued) 14th Amendment of, 52, 56

I5th Amendment of, 73

Contract labor, 68

Cooley, Judge, 68

Courts, jurisdiction of, $76,98-\mathbf{I O I}, \mathbf{I} 28$ consular, 4I, I88

territorial, 40

Cuba, 7, 14, 20, 25, 63

status of, I 73-190

Curtis, Justice, 40, I I6, I20

Danish West Indies, 69

Day, Judge W. R., 20, 72

Field, Justice, $4^{\circ}$

Florida, 9, 36, 57, 61, 63, 122, 137

"Foreign" country, I4-16, I8, I9, 24, 174 port, 79

Foreigners, status and rights, $57, \mathbf{I} 82$

France, colonies, 43

plebiscite, 60

treaties of cession, 147

French territory, 2 I

Germany, II , 43, 50

Gray, Justice, 8,40

Great Britain -

Parliament, 31, 44, 47, I 10

the Crown, I3, 31, 99, II I28, 147

British territory, 2 I

colonies, 2 I , 44, 1 10, 125, I36

contrasted with United States, 44, 45,

67,99, I01, I I0, I1 2

Guano Islands, 8

Habeas corpus, IOO, IOI

Hamilton, Mr., 73

Hanotaux, M., $2 \mathrm{I}$

Hanover, 24

Harlan, Justice, 40, 47

Harrison, Mr., 65

Hawaii, 6, 9, 59

Home market, go

House of Representatives powers regarding annexation, 22
House of Representatives (continued)powers regarding cession, $\mathbf{I}_{4} 8$

Indemnity -

Acts of, 113

for cost of war, 104

Indians, II, 15, 57, 66, 94, 95, I 86

Insurrection, $3,5 \mathrm{I}, 58,108, \mathrm{I} 20,177$

International Law, 5

duty of occupant under, I 2, I 74

private, 184

Italy, 43

Jackson, Gen., 36

Japan, 4I, 63

Java, 43

Jefferson, President, I19, I3I

, Jury, trial by, $3^{8}$

Kearny Code of New Mexico, I ro

Lacombe, Judge, I 85

Language of annexed country, 138

Lincoln, President, I30

Louisiana, 9, 35, 36, 79, 126, 131, 133, 137,165

Lucas, Mr. C. F., 125

MacArthur, Gen., I6I

McKinley, President, I19, 143, 149

Madagascar, 21

Mansfield, Lord, 6, I3, 3 I

Marshall, Chief Justice, I, 5, 8, 15, 22, 24, 40, 46, 61, 63, 82, 87, 94, 97, 122, I23, I3I, I 79

Matthews, Justice, 40

Mexico, 23, 79

Military government, I 06-Io9, I I4, I 32, I 76 occupation, 106, I I I, I 74, I 76, I89

Militia, I09, 154

Miller, Justice, 40

Mohammedan tribes, 57, 66, I40, I5I, I64

Monroe Doctrine, 166, 169

National title to land, 2, 3

Nationality of territory, 20, I $\delta_{3}$ 
Nationality (continued) persons, 20 change of, $6 \mathbf{I}$ election of, $20,59,148$

Naturalization Acts, 54

Oath of office, constitutional, 45

Passports, to Cubans, 187

Peonage, 68

Philippine Commission -

First, IOI, I13, 152

Second, I I3, I43, 153

Philippine Islands title of Spain to, I title of U. S. to, 10 description of, $\mathbf{I}$ I part of U. S., 27, 144 insurrection in, 51, 58, 129, 161-166 Tagals, $5^{8}$ value of Constitution in, 98 neglected by Congress, i 18 administration of local affairs, I24 bill for government of, 126 friars in the, $\mathbf{1} 42$ their relation to trade, 159 reasons for alienating, 158 protectorate over, $\mathbf{1 4} 8$ neutralization of, 155

Plebiscite, 59, 148

Political franchises, 70
Religious institutions, I33, 140

Russia, 43, 186

Salisbury, Lord, 60

Samoa, 155, 157

Self-government, capacity for, 153

Settlement, title by, 5

Seward, Mr., 60

Slavery, II 33, 35, 37, 65, 70, 92

Spain, title to Philippines, I

title to Sulu Islands, Io

commercial privileges in Philippines, I 8

Spanish residents in islands, $20,60, \mathbf{1} 84$ law, 135,183

“State," 39, I 74, I87

States, union of, 24

States of the Union, status and powers, I3, 39, 42, 49, 97 admission of, $8,28,32$ cession of territory, 147

Story, Justice, 24, 36, 92, 94, 156

Subjects, 64, 183

Suffrage, 49, 55, 71, 73

Sulu Islands, 10, 67, I46

Tagals, 58

Taney, Chief Justice, 5, 8, 40, I23

Tariffs, 90

(See Commerce, Taxation)

Taylor, President, I I 6

questions, $7,8,28,32,105,107,148$, Taxation, federal, 36, 49, 84-87

I $79, \mathbf{1} 85$

power in U. S., I3, 42

uniformity, I8, 34, 77, 82, 86, 90, I I 2

in Territories, 88-90

institutions in annexed territories, Territories of U.S.-

\section{I30, I3 I}

Polk, President, 37, 119

Polygamy, 140 status of, 15,39, 53 power of Congress over, 122 "popular sovereignty" in, 70

Porto Rico, 6, 7, 14, 15, 22, 24, 25, 35, administration of, $83,88,124$

$$
8 \mathrm{I}, 107, \mathbf{1} 16,135
$$

Government Act, 32, 82, 108

President of U. S. -

Texas, 6,9

Treaty, construction of, 16-19 subordinate to Constitution, 17

powers in U. S., $3 \mathbf{I}, 52,76,80,8 \mathrm{I}$, I06-I 2 I, I 44 abroad, 25, III, I 76 of annexation, $5-7,59,148$ ratification of, 22 the making of a, 13,147 distinguished from British Crown, 13, Treaty of Paris, 3, 10, 16, I 7, 22, 132 31, 99, I10, I20, I 24, I28, 147

Protectorate, 10, 26, 46, 148, 175
Article IV, 18
Article I, 173, 174, I89 
Treaty of Paris (continued) -

Article VIII, I42

Article IX, 18, 20, 62, 63, 183

Treaty of San Ildefonso, 153

"United States," meanings of, I2-15, $42,52,78,188$

" United States of America," 35, 45 Utah, 40, 54
Uti possidetis, $\mathbf{1} 80$

Waite, Chief Justice, 40

War (see Belligerent right, Conquest, Insurrection) -

change of title by, 2,5

termination of, 107

Webster, Mr., 31, 37

Wilson, Justice, 64, 73 


\section{ERRATA}

Page 20, last line, for Cogordon read Cogordan. Page 45 , line 3 , for is not in line with read is in line with. 



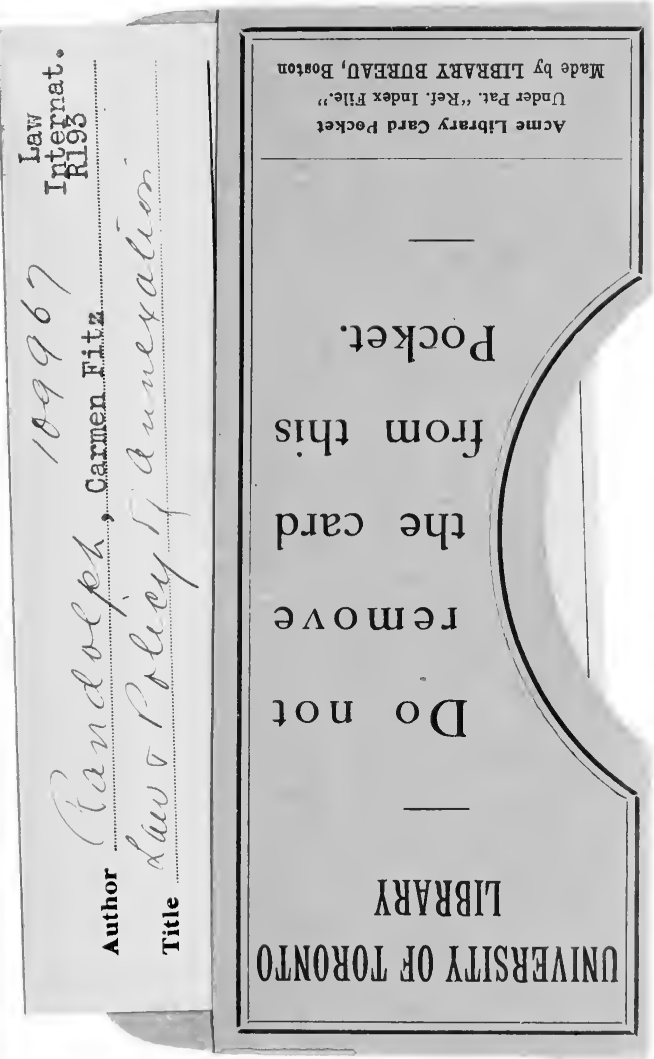




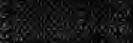

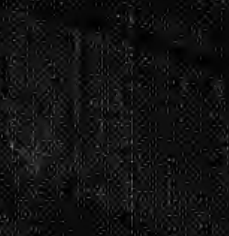

. 